Supporting Information

\title{
Redox-Induced Structural Reorganization Dictates Kinetics of Cobalt(III)-Hydride Formation via Proton-Coupled Electron Transfer
}

Daniel A. Kurtz, ${ }^{a}$ Debanjan Dhar, ${ }^{a}$ Noémie Elgrishi, ${ }^{a, b}$ Banu Kandemir, ${ }^{a}$ Sean F. McWilliams, ${ }^{a}$ William C. Howland, ${ }^{a}$ Chun-Hsing Chen, ${ }^{a}$ Jillian L. Dempsey ${ }^{a *}$

${ }^{a}$ Department of Chemistry, University of North Carolina at Chapel Hill, Chapel Hill, North Carolina 27599-3290, United States

${ }^{b}$ Department of Chemistry, Louisiana State University, 232 Choppin Hall, Baton Rouge, LA 70803, United States 


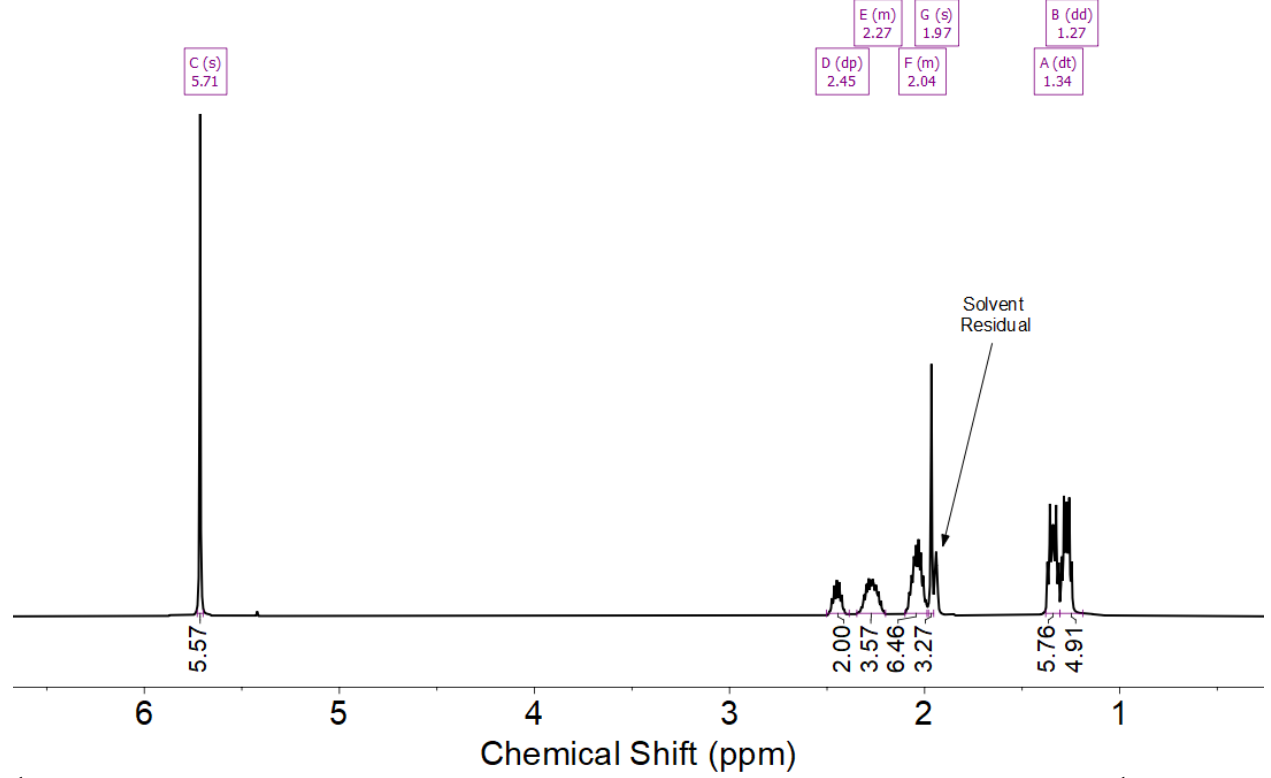

Figure S1. ${ }^{1} \mathrm{H}$ NMR spectrum of $\left[\mathrm{CoCp}(\right.$ depe $\left.)\left(\mathrm{NCCH}_{3}\right)\right]\left[\mathrm{PF}_{6}\right]_{2}$ (2) in $\mathrm{CD}_{3} \mathrm{CN} .{ }^{1} \mathrm{H} N M R(600 \mathrm{MHz}$, $\left.\mathrm{CD}_{3} \mathrm{CN}\right) \delta 5.71(\mathrm{~s}, 5 \mathrm{H}), 2.45(\mathrm{dp}, J=15.0,7.4 \mathrm{~Hz}, 2 \mathrm{H}), 2.35-2.20(\mathrm{~m}, 4 \mathrm{H}), 2.11-1.98(\mathrm{~m}, 6 \mathrm{H})$, $1.97(\mathrm{~s}, 3 \mathrm{H}), 1.34(\mathrm{dt}, J=19.0,7.7 \mathrm{~Hz}, 6 \mathrm{H}), 1.27(\mathrm{td}, J=16.4,7.4 \mathrm{~Hz}, 6 \mathrm{H})$.

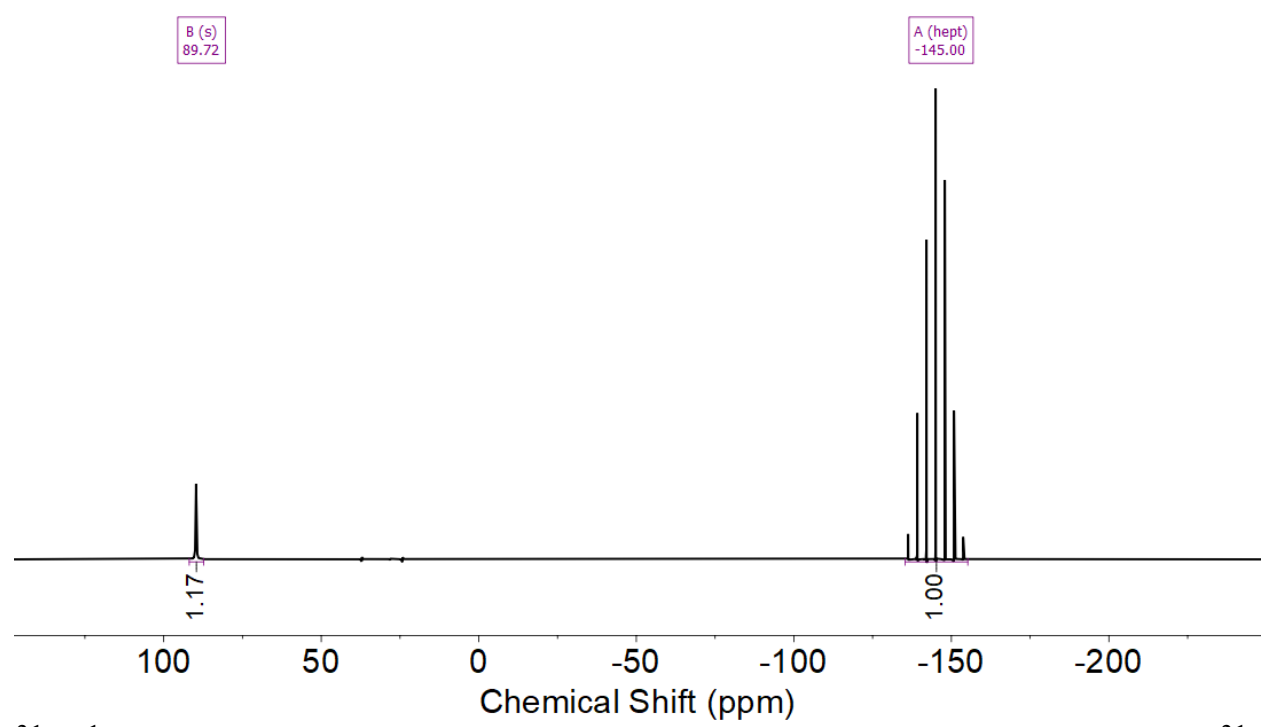

Figure S2. ${ }^{31} \mathrm{P}\left\{{ }^{1} \mathrm{H}\right\}$ NMR spectrum of $\left[\mathrm{CoCp}(\right.$ depe $\left.)\left(\mathrm{NCCH}_{3}\right)\right]\left[\mathrm{PF}_{6}\right]_{2}(2)$ in $\mathrm{CD}_{3} \mathrm{CN} .{ }^{31} \mathrm{P}\left\{{ }^{1} \mathrm{H}\right\} \mathrm{NMR}$ $\left(243 \mathrm{MHz}, \mathrm{CD}_{3} \mathrm{CN}\right) \delta 89.72(2 \mathrm{P}),-145.00$ (hept, $J=705.7 \mathrm{~Hz}, 2 \mathrm{P}$ ). 


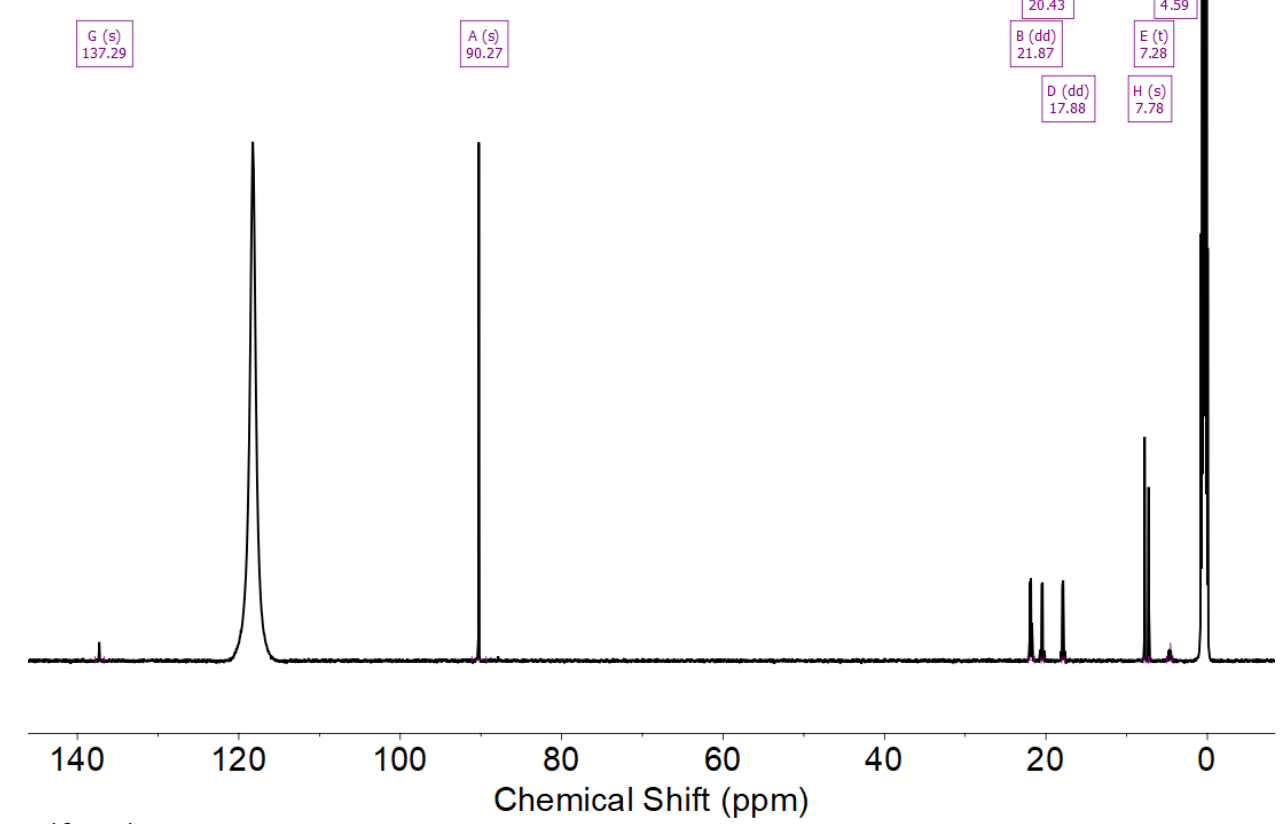

Figure S3. ${ }^{13} \mathrm{C}\left\{{ }^{1} \mathrm{H}\right\}$ NMR spectrum of $\left[\mathrm{CoCp}(\mathrm{depe})\left(\mathrm{NCCH}_{3}\right)\right]\left[\mathrm{PF}_{6}\right]_{2}(2)$ in $\mathrm{CD}_{3} \mathrm{CN} .{ }^{13} \mathrm{C}\left\{{ }^{1} \mathrm{H}\right\}$ NMR (151 MHz, $\left.\mathrm{CD}_{3} \mathrm{CN}\right) \delta 137.29,90.27,21.87(\mathrm{dd}, J=21.4,18.3 \mathrm{~Hz}), 20.43(\mathrm{dd}, J=15.6,12.8$ $\mathrm{Hz}), 17.88(\mathrm{dd}, J=15.0,12.2 \mathrm{~Hz}), 7.78,4.59$ (p, $J=21.4 \mathrm{~Hz})$.
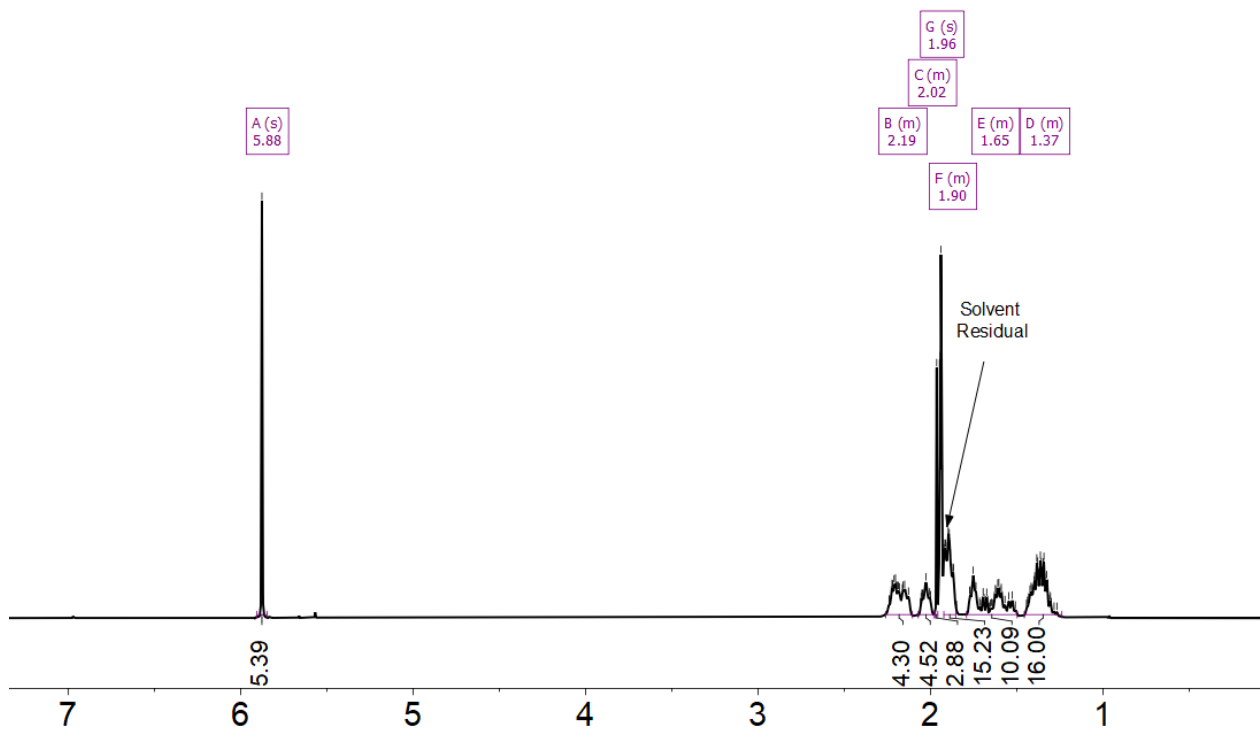

Chemical Shift (ppm)

Figure S4. ${ }^{1} \mathrm{H}$ NMR spectrum of $\left[\mathrm{CoCp}(\mathrm{dcpe})\left(\mathrm{NCCH}_{3}\right)\right]\left[\mathrm{PF}_{6}\right]_{2}(\mathbf{3})$ in $\mathrm{CD}_{3} \mathrm{CN} .{ }^{1} \mathrm{H} N M R(600 \mathrm{MHz}$, $\left.\mathrm{CD}_{3} \mathrm{CN}\right) \delta 5.88(\mathrm{~s}, 5 \mathrm{H}), 2.26-2.11(\mathrm{~m}, 4 \mathrm{H}), 2.07-1.98(\mathrm{~m}, 4 \mathrm{H}), 1.96(\mathrm{~s}, 3 \mathrm{H}), 1.93-1.85(\mathrm{~m}$, $14 \mathrm{H}), 1.79-1.50(\mathrm{~m}, 10 \mathrm{H}), 1.46-1.29(\mathrm{~m}, 16 \mathrm{H})$. 


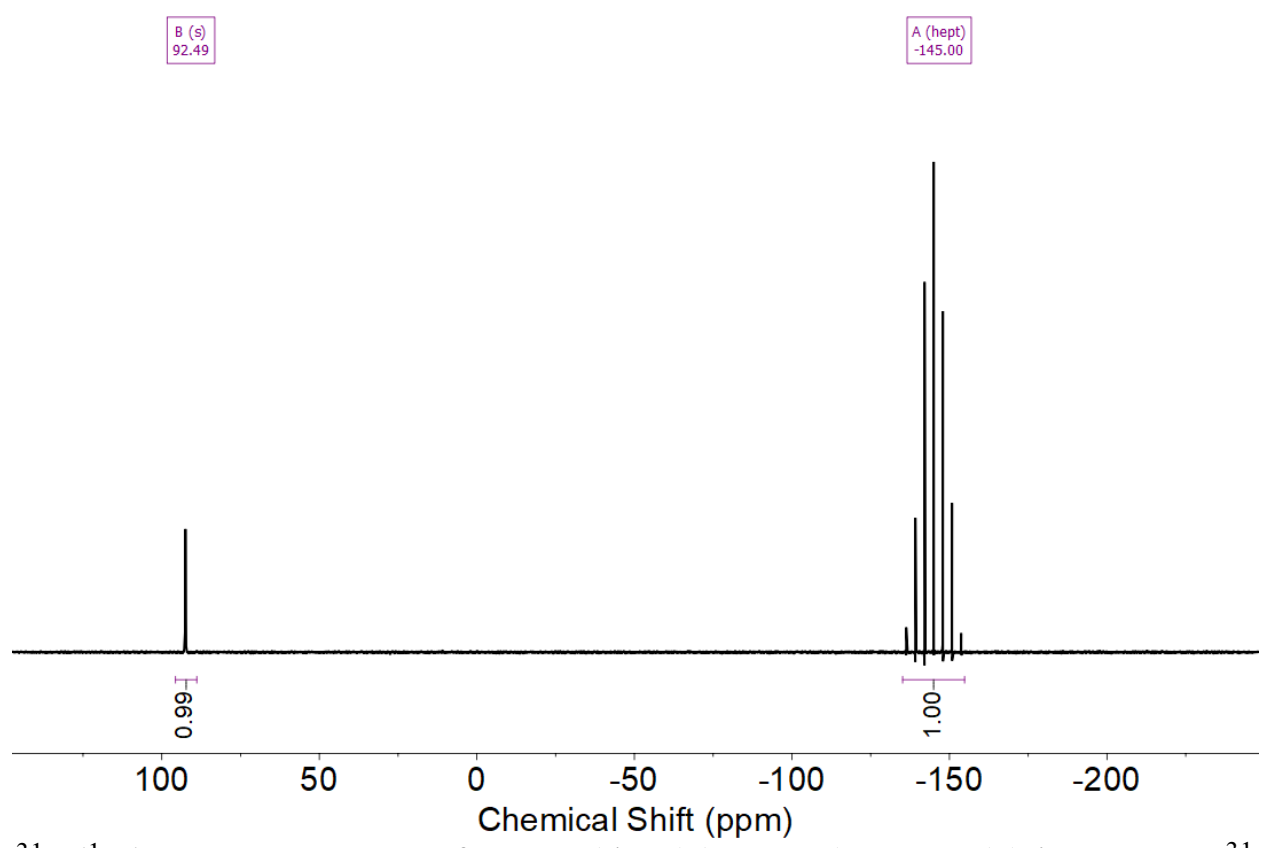

Figure S5. ${ }^{31} \mathrm{P}\left\{{ }^{1} \mathrm{H}\right\}$ NMR spectrum of $\left[\mathrm{CoCp}(\mathrm{dcpe})\left(\mathrm{NCCH}_{3}\right)\right]\left[\mathrm{PF}_{6}\right]_{2}(3)$ in $\mathrm{CD}_{3} \mathrm{CN} .{ }^{31} \mathrm{P}\left\{{ }^{1} \mathrm{H}\right\}$ NMR (243 MHz, CD $\left.{ }_{3} \mathrm{CN}\right) \delta 92.49(2 \mathrm{P}),-145.00$ (hept, $J=705.7 \mathrm{~Hz}, 2 \mathrm{P}$ ).
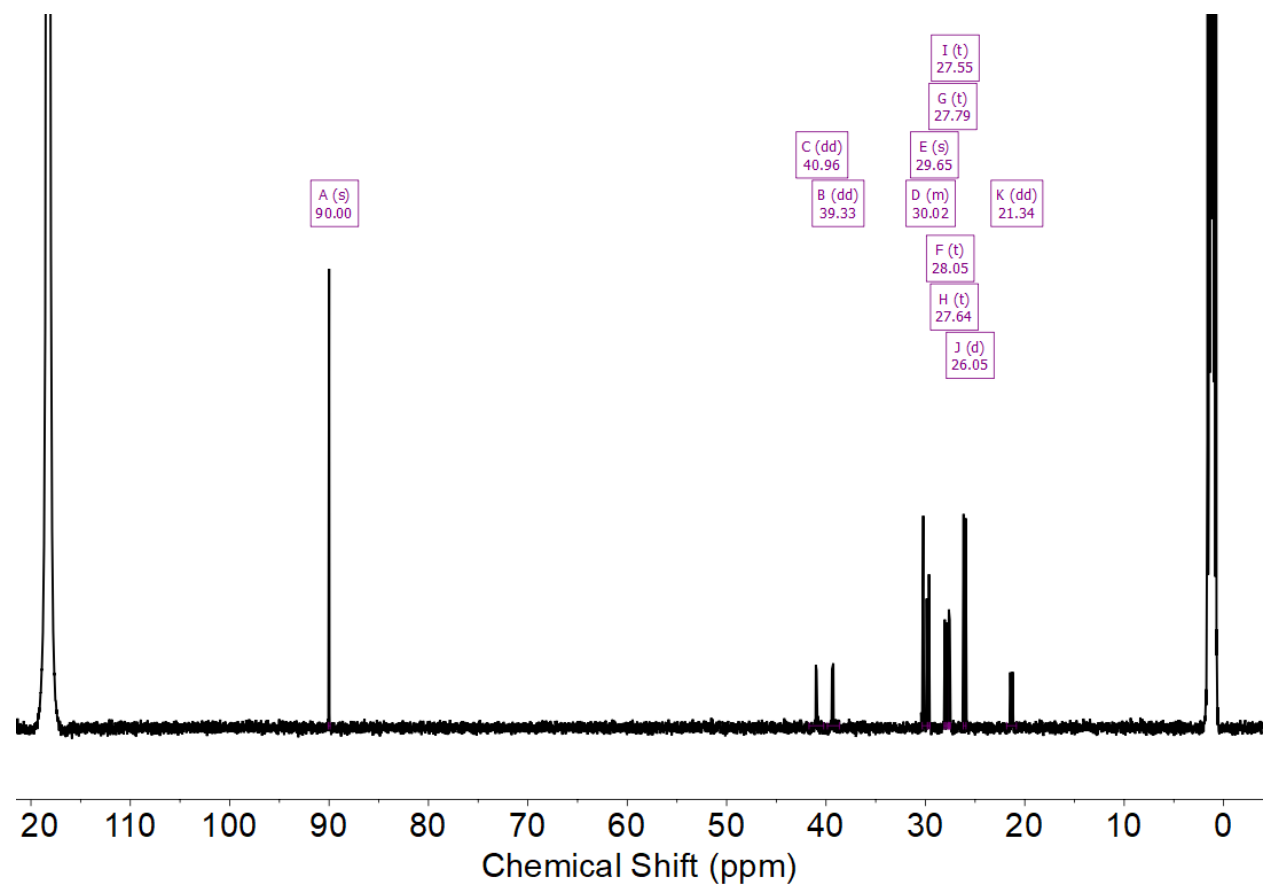

Figure S6. ${ }^{13} \mathrm{C}\left\{{ }^{1} \mathrm{H}\right\}$ NMR spectrum of $\left[\mathrm{CoCp}(\mathrm{dcpe})\left(\mathrm{NCCH}_{3}\right)\right]\left[\mathrm{PF}_{6}\right]_{2}(3)$ in $\mathrm{CD}_{3} \mathrm{CN} .{ }^{13} \mathrm{C}\left\{{ }^{1} \mathrm{H}\right\}$ NMR $\left(151 \mathrm{MHz}, \mathrm{CD}_{3} \mathrm{CN}\right) \delta 139.53,90.00,40.96(\mathrm{dd}, J=11.4,9.3 \mathrm{~Hz}), 39.33(\mathrm{dd}, J=11.5,9.2$ Hz), 30.22, $30.10(\mathrm{td}, J=60.6,2.7 \mathrm{~Hz}), 29.65,28.05$ (t, $J=6.1 \mathrm{~Hz}), 27.79$ (t, $J=5.3 \mathrm{~Hz}), 27.64$ $(\mathrm{t}, J=5.4 \mathrm{~Hz}), 27.55(\mathrm{t}, J=5.7 \mathrm{~Hz}), 26.05(\mathrm{~d}, J=33.0 \mathrm{~Hz}), 21.34(\mathrm{dd}, J=19.4,15.5 \mathrm{~Hz})$. 


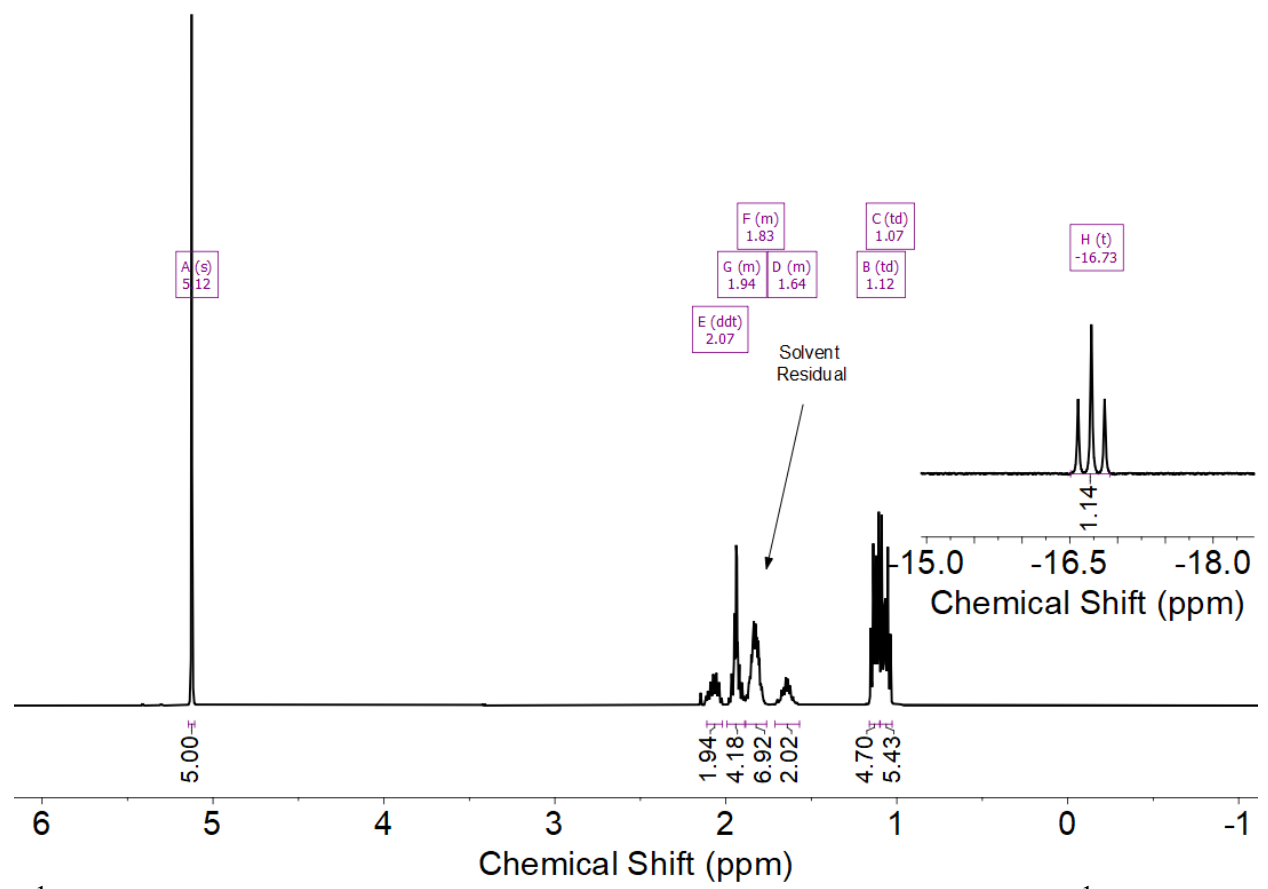

Figure S7. ${ }^{1} \mathrm{H}$ NMR spectrum of $[\mathrm{HCoCp}($ depe $)]\left[\mathrm{PF}_{6}\right](5)$ in $\mathrm{CD}_{3} \mathrm{CN} .{ }^{1} \mathrm{H}$ NMR $(500 \mathrm{MHz}$, $\left.\mathrm{CD}_{3} \mathrm{CN}\right) \delta 5.12(\mathrm{~s}, 5 \mathrm{H}), 2.07(\mathrm{ddt}, J=15.0,10.2,7.6 \mathrm{~Hz}, 2 \mathrm{H}), 1.99-1.90(\mathrm{~m}, 5 \mathrm{H}), 1.88-1.76$ $(\mathrm{m}, 4 \mathrm{H}), 1.74-1.57(\mathrm{~m}, 2 \mathrm{H}), 1.12(\mathrm{td}, J=16.3,7.6 \mathrm{~Hz}, 6 \mathrm{H}), 1.07$ (td, $J=18.2,7.6 \mathrm{~Hz}, 6 \mathrm{H})$, $16.73(\mathrm{t}, J=69.7 \mathrm{~Hz}, 1 \mathrm{H})$.

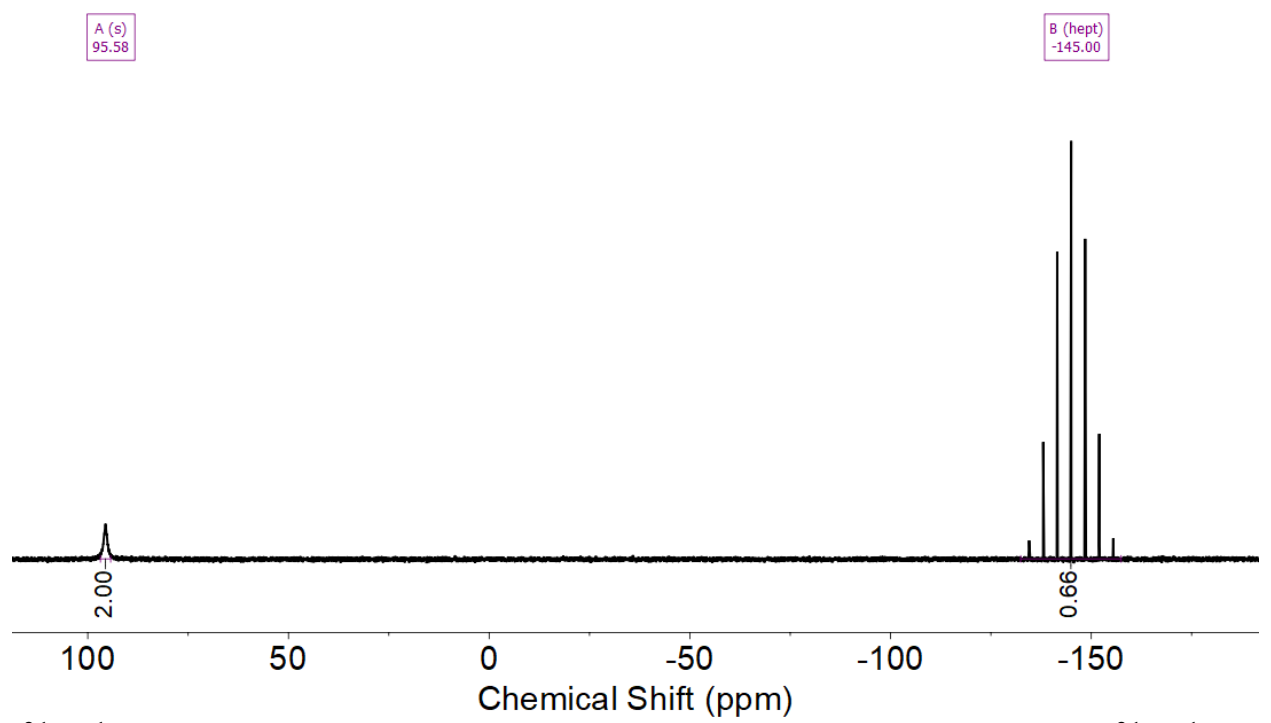

Figure S8. ${ }^{31} \mathrm{P}\left\{{ }^{1} \mathrm{H}\right\}$ NMR spectrum of $[\mathrm{HCoCp}(\mathrm{depe})]\left[\mathrm{PF}_{6}\right](5)$ in $\mathrm{CD}_{3} \mathrm{CN} .{ }^{31} \mathrm{P}\left\{{ }^{1} \mathrm{H}\right\}$ NMR $(202$ $\mathrm{MHz}, \mathrm{CD}_{3} \mathrm{CN}$ ) $\delta 95.58$ (1P), -145.00 (hept, $J=706.5 \mathrm{~Hz}, 2 \mathrm{P}$ ). 

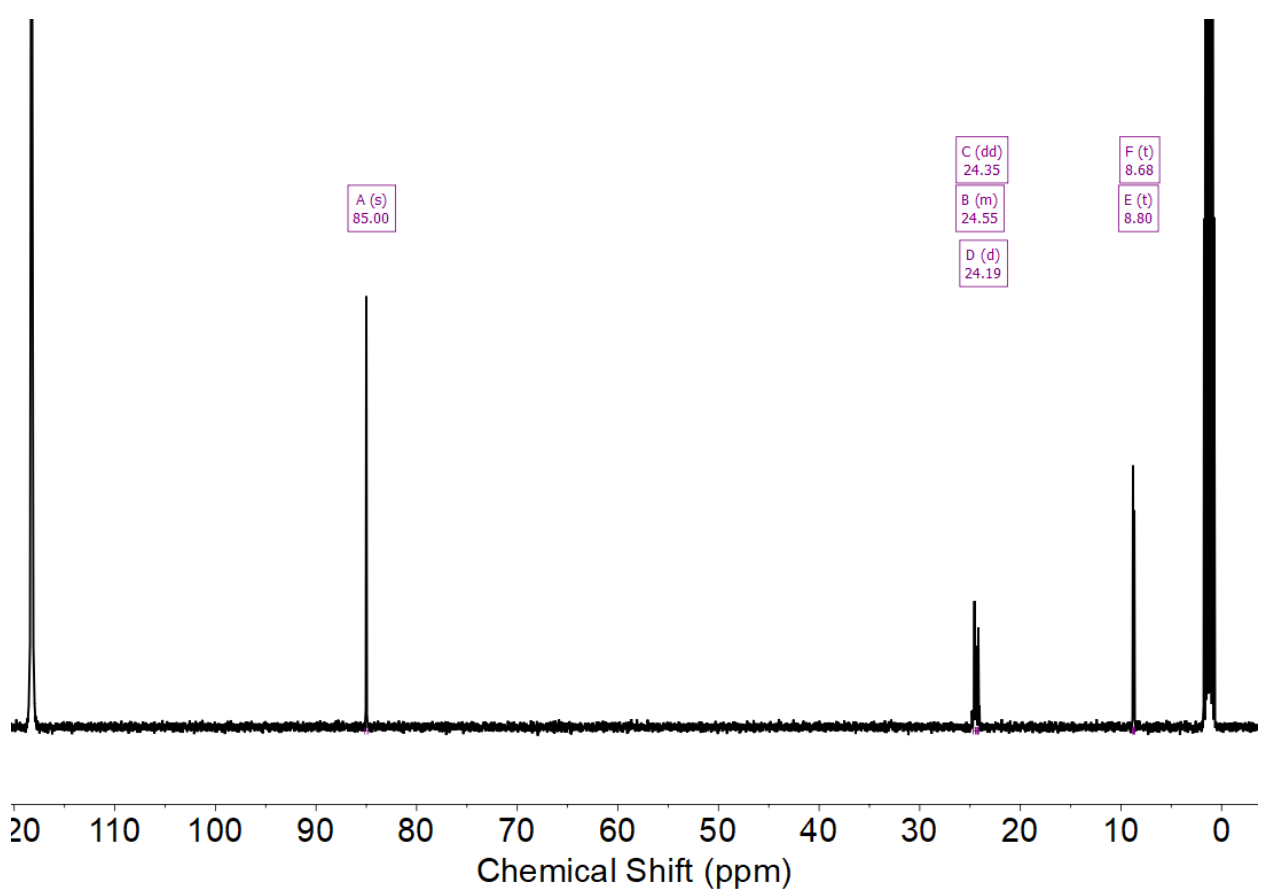

Figure S9. ${ }^{13} \mathrm{C}\left\{{ }^{1} \mathrm{H}\right\}$ NMR spectrum of $[\mathrm{HCoCp}($ depe $)]\left[\mathrm{PF}_{6}\right](5)$ in $\mathrm{CD}_{3} \mathrm{CN} .{ }^{13} \mathrm{C}\left\{{ }^{1} \mathrm{H}\right\} \mathrm{NMR}(126$ $\left.\mathrm{MHz}, \mathrm{CD}_{3} \mathrm{CN}\right) \delta 85.00,24.68-24.44(\mathrm{~m}), 24.35(\mathrm{dd}, J=7.4,3.9 \mathrm{~Hz}), 24.19$ (d, $\left.J=3.4 \mathrm{~Hz}\right), 8.80$ $(\mathrm{t}, J=1.4 \mathrm{~Hz}), 8.68(\mathrm{t}, J=2.7 \mathrm{~Hz})$.

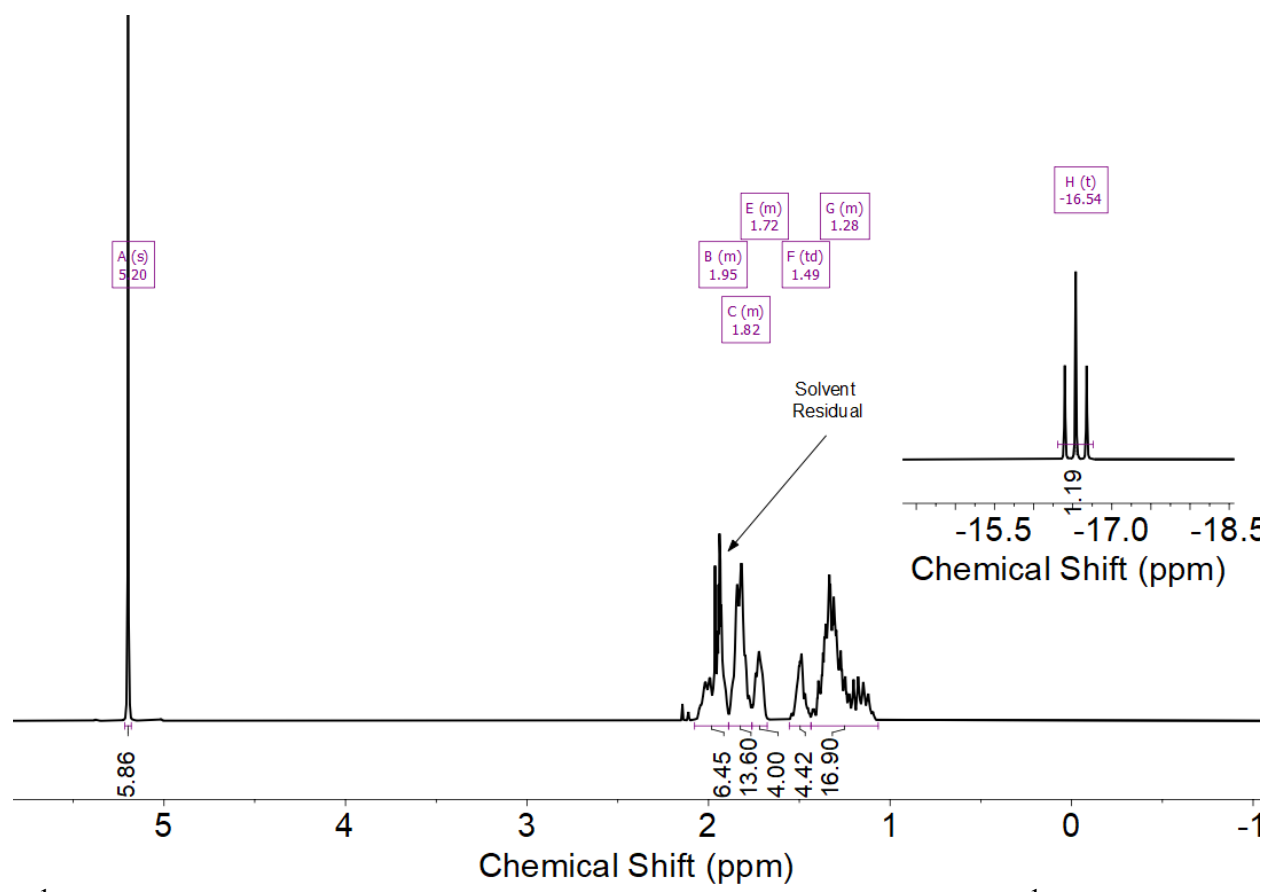

Figure S10. ${ }^{1} \mathrm{H}$ NMR spectrum of $[\mathrm{HCoCp}(\mathrm{dcpe})]\left[\mathrm{PF}_{6}\right](6)$ in $\mathrm{CD}_{3} \mathrm{CN} .{ }^{1} \mathrm{H} \mathrm{NMR}(500 \mathrm{MHz}$, $\left.\mathrm{CD}_{3} \mathrm{CN}\right) \delta 5.20(\mathrm{~s}, 5 \mathrm{H}), 2.08-1.96(\mathrm{~m}, 6 \mathrm{H}), 1.94-1.76(\mathrm{~m}, 14 \mathrm{H}), 1.76-1.68(\mathrm{~m}, 4 \mathrm{H}), 1.56-$ $1.44(\mathrm{~m}, 4 \mathrm{H}), 1.43-1.23(\mathrm{~m}, 20 \mathrm{H}),-16.54(\mathrm{t}, J=69.8 \mathrm{~Hz}, 1 \mathrm{H})$. 


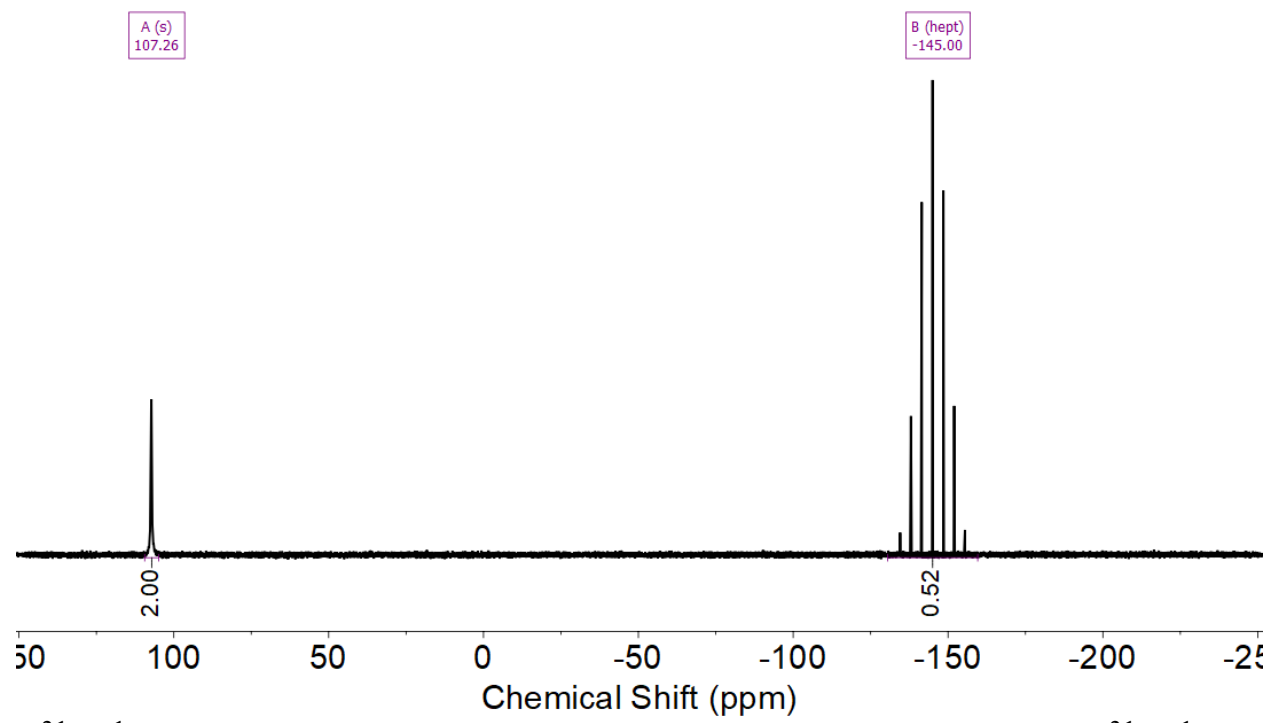

Figure S11. ${ }^{31} \mathrm{P}\left\{{ }^{1} \mathrm{H}\right\}$ NMR spectrum of $[\mathrm{HCoCp}(\mathrm{dcpe})]\left[\mathrm{PF}_{6}\right](6)$ in $\mathrm{CD}_{3} \mathrm{CN} .{ }^{31} \mathrm{P}\left\{{ }^{1} \mathrm{H}\right\} \mathrm{NMR}(202$ $\mathrm{MHz}, \mathrm{CD}_{3} \mathrm{CN}$ ) $\delta 107.26,-145.00$ (hept, $J=706.5 \mathrm{~Hz}$ ).

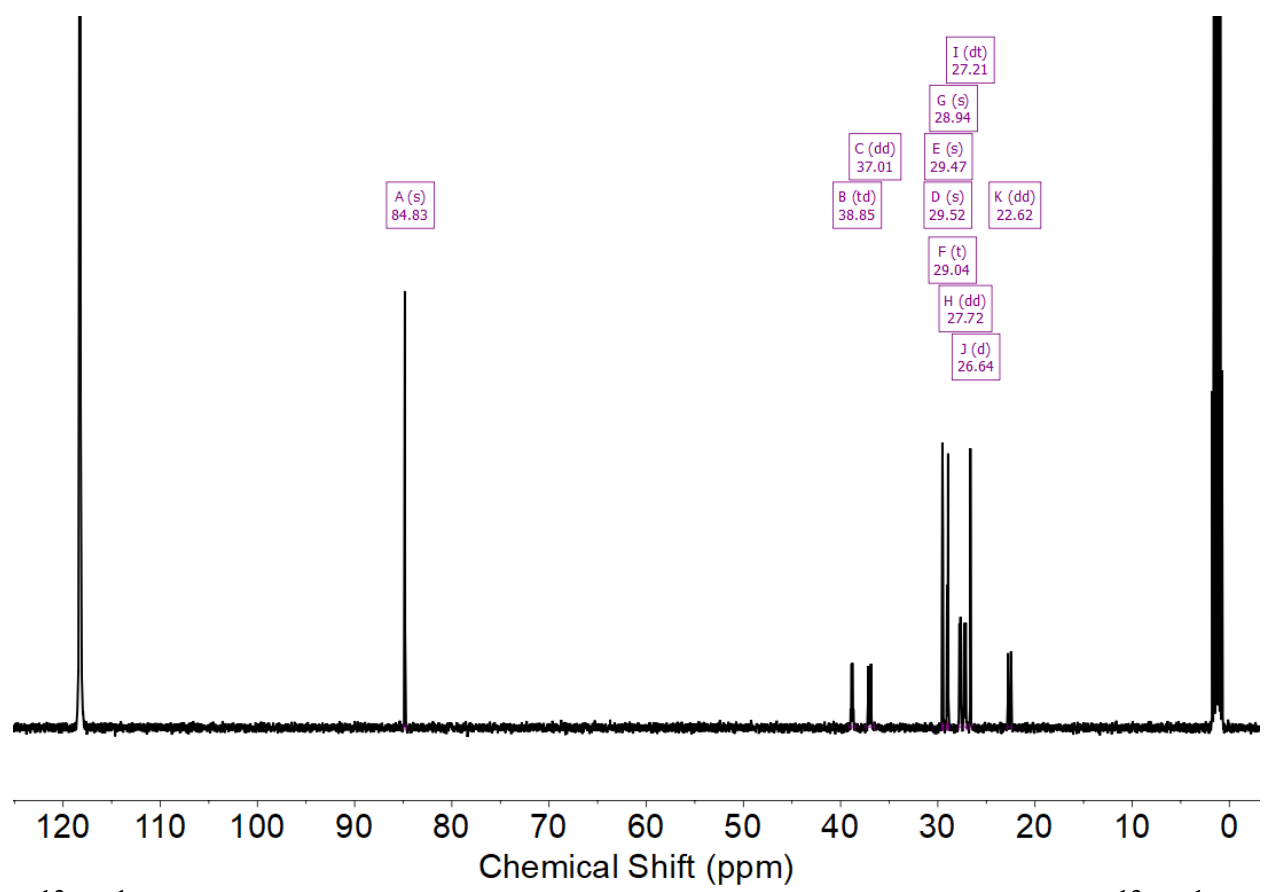

Figure S12. ${ }^{13} \mathrm{C}\left\{{ }^{1} \mathrm{H}\right\}$ NMR spectrum of $[\mathrm{HCoCp}(\mathrm{dcpe})]\left[\mathrm{PF}_{6}\right](6)$ in $\mathrm{CD}_{3} \mathrm{CN} \cdot{ }^{13} \mathrm{C}\left\{{ }^{1} \mathrm{H}\right\} \mathrm{NMR}(126$ $\left.\mathrm{MHz}, \mathrm{CD}_{3} \mathrm{CN}\right) \delta 84.83,38.85(\mathrm{td}, J=18.1,8.1 \mathrm{~Hz}), 37.01(\mathrm{td}, J=18.5,8.1 \mathrm{~Hz}), 29.52,29.47$, $29.04(\mathrm{t}, J=2.4 \mathrm{~Hz}), 28.94,27.72(\mathrm{td}, J=12.6,6.1 \mathrm{~Hz}), 27.21(\mathrm{dt}, J=19.2,5.9 \mathrm{~Hz}), 26.64$ (d, $J=$ $2.3 \mathrm{~Hz}), 22.62(\mathrm{dd}, J=23.4,17.0 \mathrm{~Hz})$. 


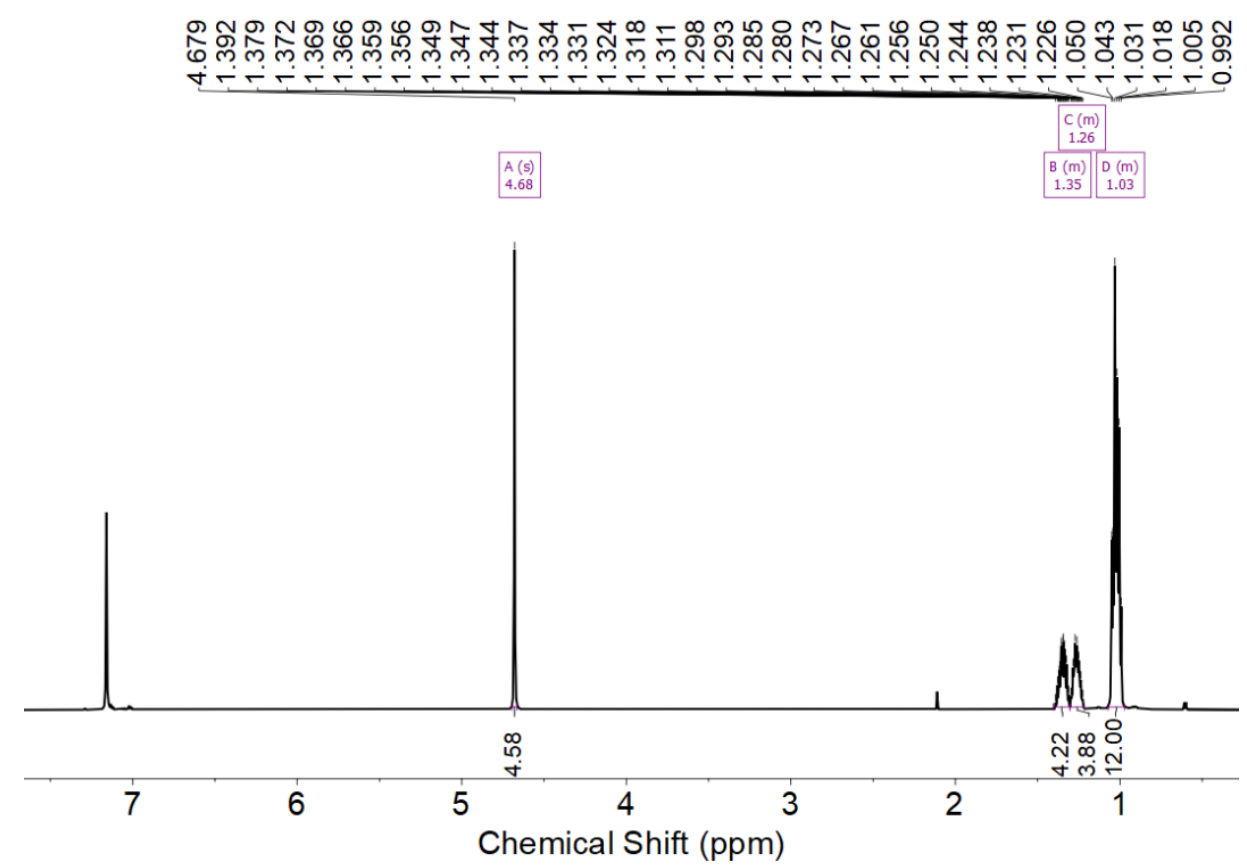

Figure S13. ${ }^{1} \mathrm{H}$ NMR spectrum of $\mathrm{CoCp}($ depe $)$ in $\mathrm{C}_{6} \mathrm{D}_{6} .{ }^{1} \mathrm{H} \mathrm{NMR}\left(600 \mathrm{MHz}, \mathrm{C}_{6} \mathrm{D}_{6}\right) \delta 4.68$ (s, $5 \mathrm{H}), 1.40-1.30(\mathrm{~m}, 4 \mathrm{H}), 1.30-1.22(\mathrm{~m}, 4 \mathrm{H}), 1.07-0.97(\mathrm{~m}, 12 \mathrm{H})$.

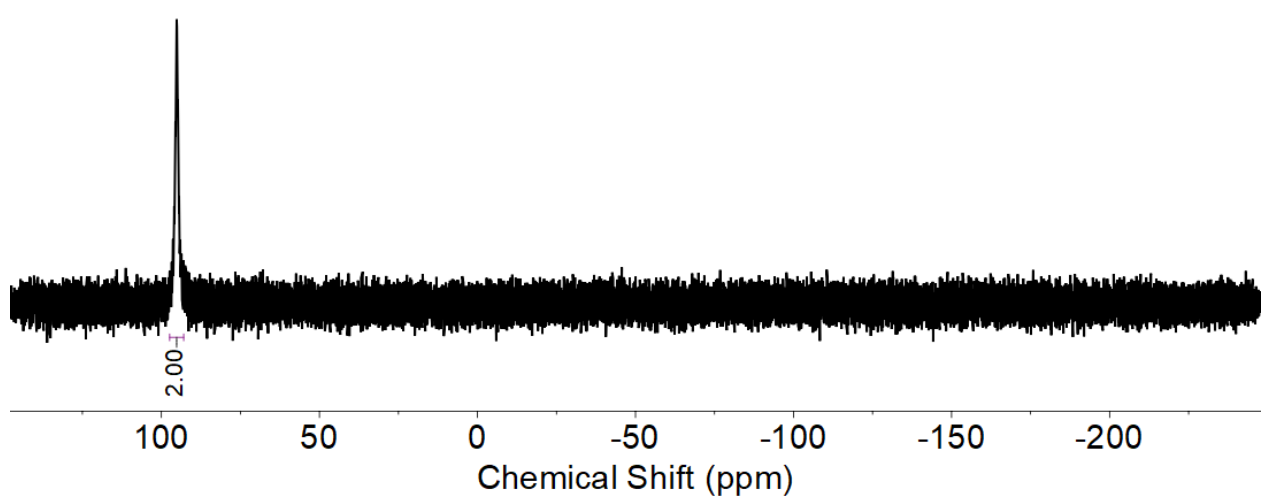

Figure S14. ${ }^{31} \mathrm{P}\left\{{ }^{1} \mathrm{H}\right\}$ NMR spectrum of $\mathrm{CoCp}($ depe $)$ in $\mathrm{C}_{6} \mathrm{D}_{6} \cdot{ }^{31} \mathrm{P}\left\{{ }^{1} \mathrm{H}\right\} \mathrm{NMR}\left(243 \mathrm{MHz}, \mathrm{C}_{6} \mathrm{D}_{6}\right) \delta$ 95.12 . 


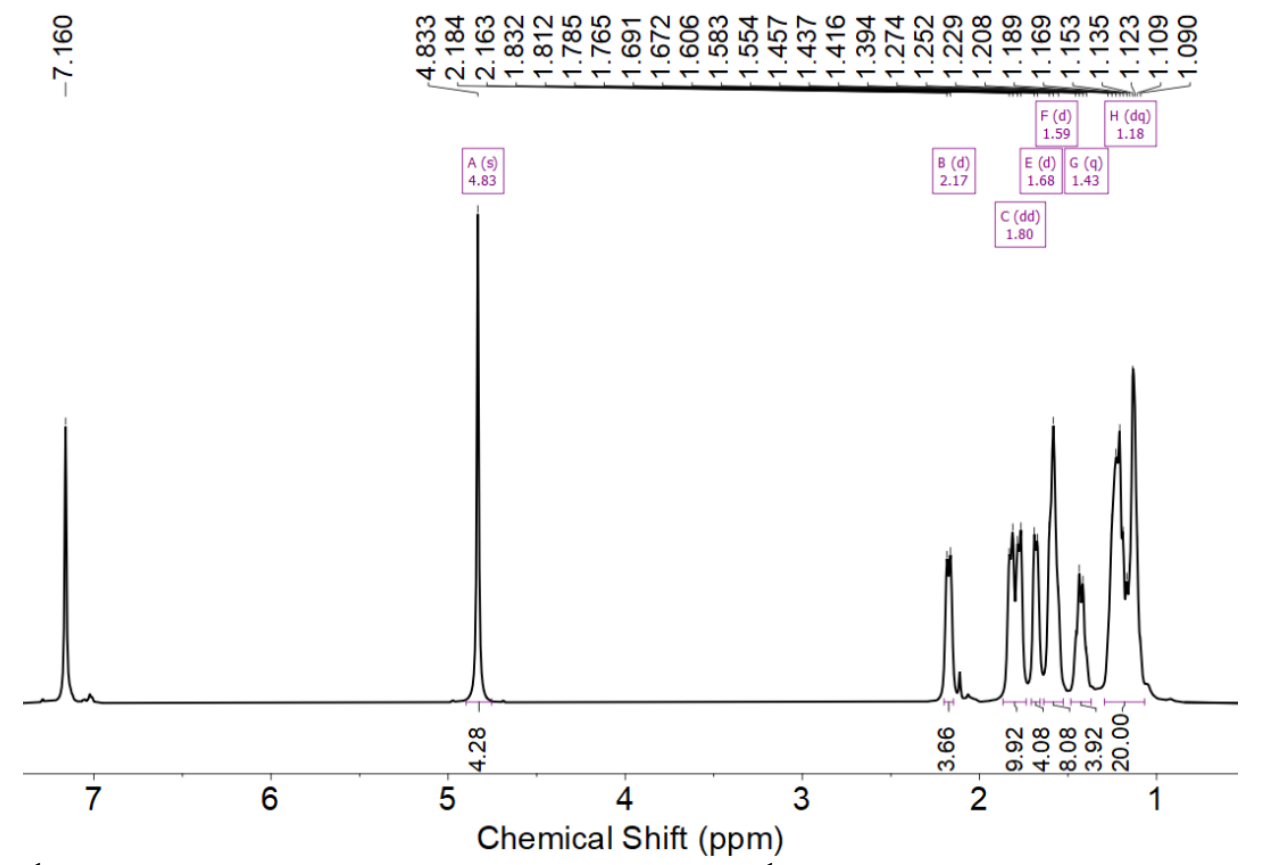

Figure S15. ${ }^{1} \mathrm{H}$ NMR spectrum of CoCp(dcpe) in $\mathrm{C}_{6} \mathrm{D}_{6} .{ }^{1} \mathrm{H}$ NMR (600 MHz, C6D6) $\delta 4.83$ (s, $5 \mathrm{H}), 2.17(\mathrm{~d}, \mathrm{~J}=12.7 \mathrm{~Hz}, 4 \mathrm{H}), 1.80(\mathrm{dd}, \mathrm{J}=28.2,11.9 \mathrm{~Hz}, 8 \mathrm{H}), 1.68(\mathrm{~d}, \mathrm{~J}=11.2 \mathrm{~Hz}, 4 \mathrm{H}), 1.59$ $(\mathrm{d}, \mathrm{J}=14.0 \mathrm{~Hz}, 8 \mathrm{H}), 1.43(\mathrm{q}, \mathrm{J}=12.7 \mathrm{~Hz}, 4 \mathrm{H}), 1.18(\mathrm{~m}, 20 \mathrm{H})$.

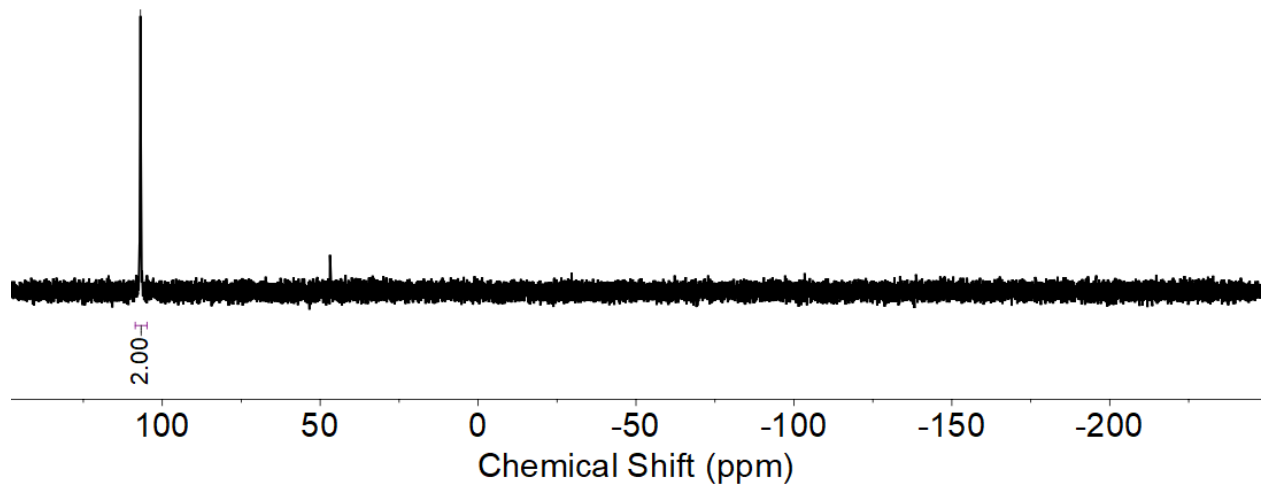

Figure S16. ${ }^{31} \mathrm{P}\left\{{ }^{1} \mathrm{H}\right\}$ NMR spectrum of $\mathrm{CoCp}(\mathrm{dcpe})$ in $\mathrm{C}_{6} \mathrm{D}_{6} .{ }^{31} \mathrm{P}\left\{{ }^{1} \mathrm{H}\right\} \mathrm{NMR}\left(243 \mathrm{MHz}, \mathrm{C}_{6} \mathrm{D}_{6}\right) \delta$ 106.89 . 


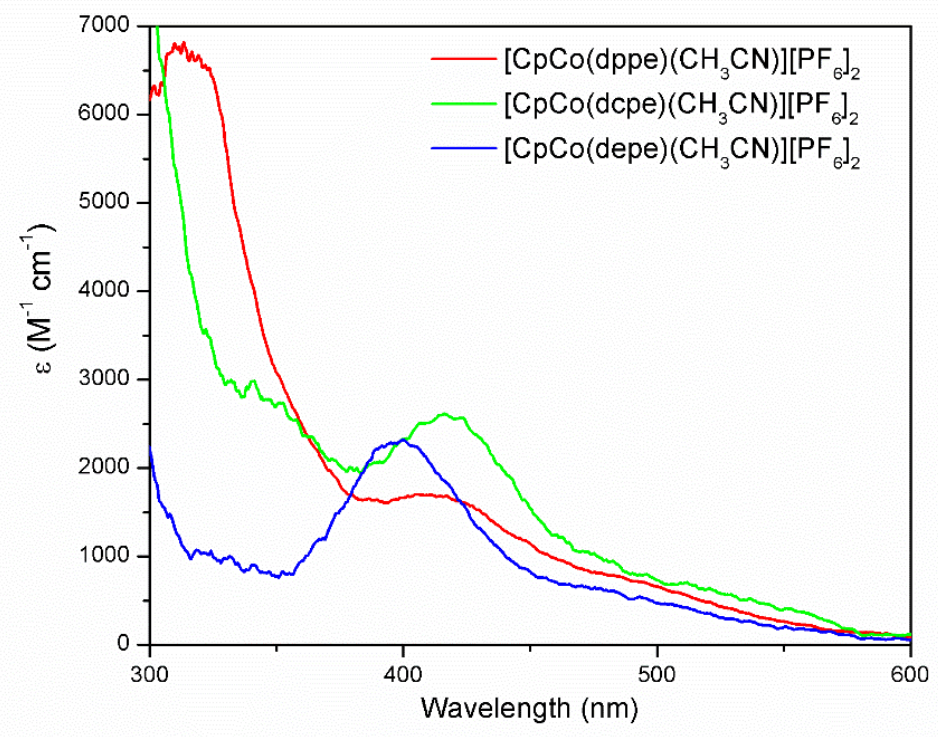

Figure S17. UV-visible absorbance spectra of 1-3 in $\mathrm{CH}_{3} \mathrm{CN} . \lambda_{\max }(\mathbf{1})=409 \mathrm{~nm} ; \lambda_{\max }(\mathbf{2})=398$ $\mathrm{nm} ; \lambda_{\max }(\mathbf{3})=417 \mathrm{~nm}$.

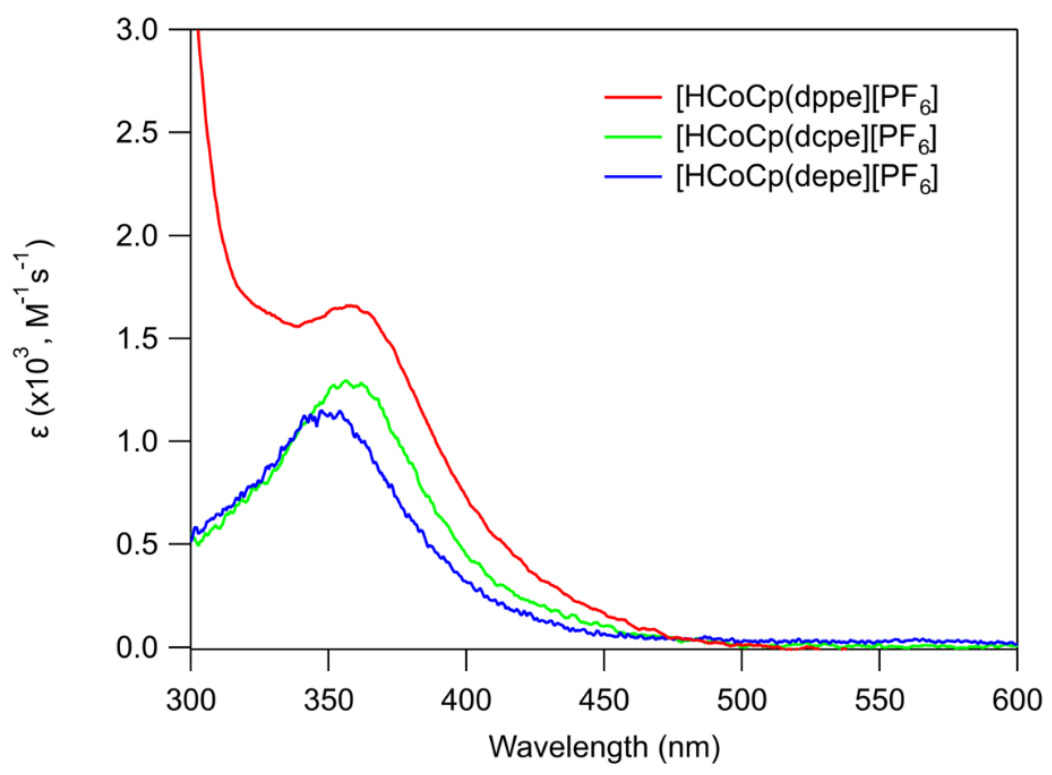

Figure S18. UV-visible absorbance spectra of $[\mathrm{HCoCp}(\mathrm{dppe})]\left[\mathrm{PF}_{6}\right](4),[\mathrm{HCoCp}(\mathrm{dcpe})]\left[\mathrm{PF}_{6}\right]$

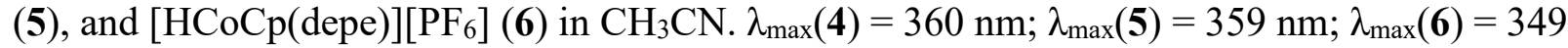
nm. 

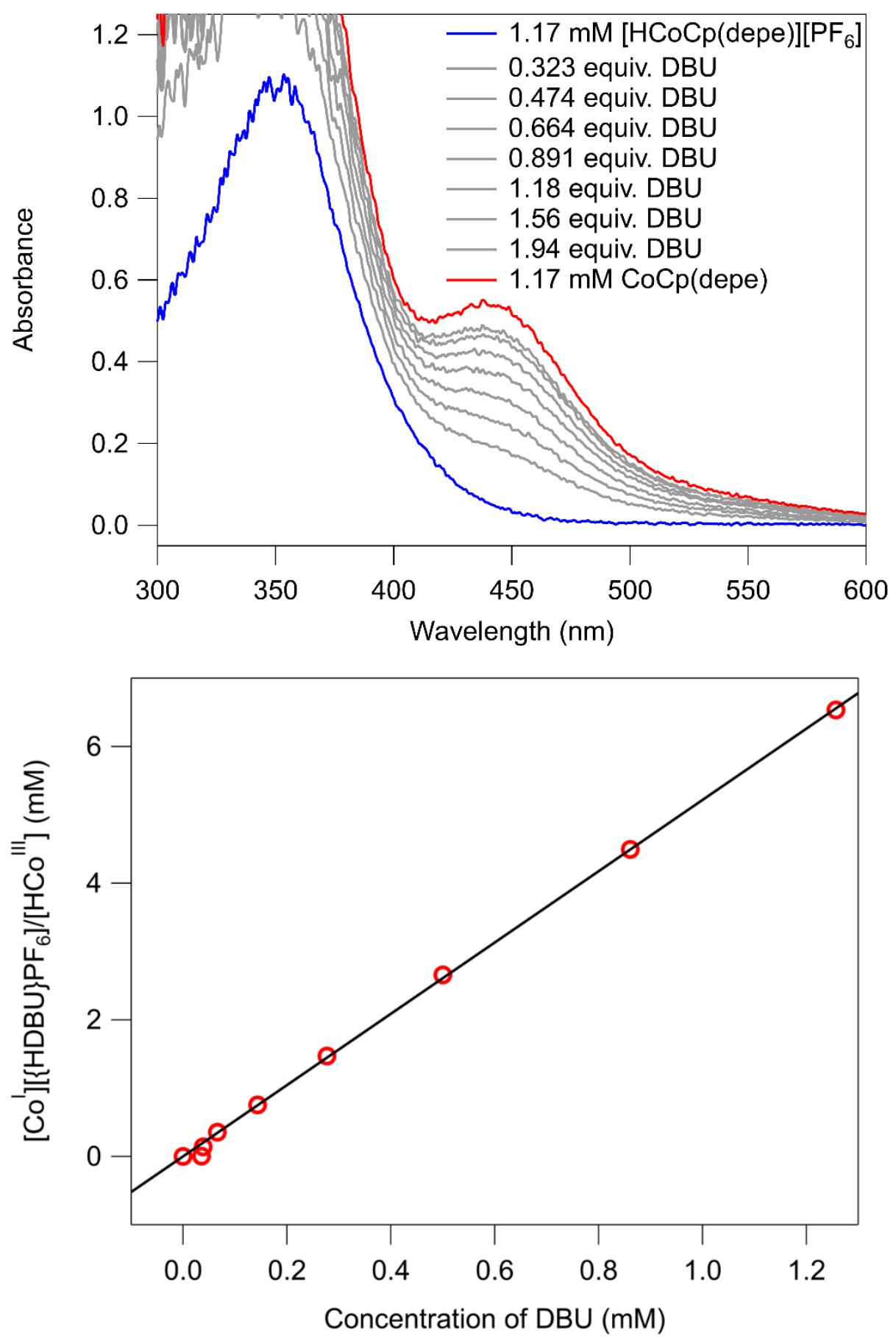

Figure S19. Spectrophotometric titration in $5 \%$ toluene in $\mathrm{CH}_{3} \mathrm{CN}$ starting with $1.17 \mathrm{mM}$ $[\mathrm{HCoCp}(\mathrm{depe})]\left[\mathrm{PF}_{6}\right](\mathbf{5})$ (blue trace -) and titrating in increasing amounts of DBU (gray traces). $\mathrm{UV} / \mathrm{vis}$ absorbance spectrum of $1.17 \mathrm{mM} \mathrm{CoCp}(\mathrm{dcpe})$ is shown to indicate end point (red trace -). The absorbance at $500 \mathrm{~nm}$ and the extinction coefficients of $[\mathrm{HCoCp}($ depe $)]\left[\mathrm{PF}_{6}\right]$ and $\mathrm{CoCp}$ (depe) were used to calculate concentration of each species as a function of added base. Linear regression of the equation for the acid base equilibrium between the species and the known $\mathrm{p} K_{\mathrm{a}}$ of DBU was used to determine the $\mathrm{p} K_{\mathrm{a}}$ of $[\mathrm{HCoCp}(\mathrm{depe})]\left[\mathrm{PF}_{6}\right]$ as 23.6. 

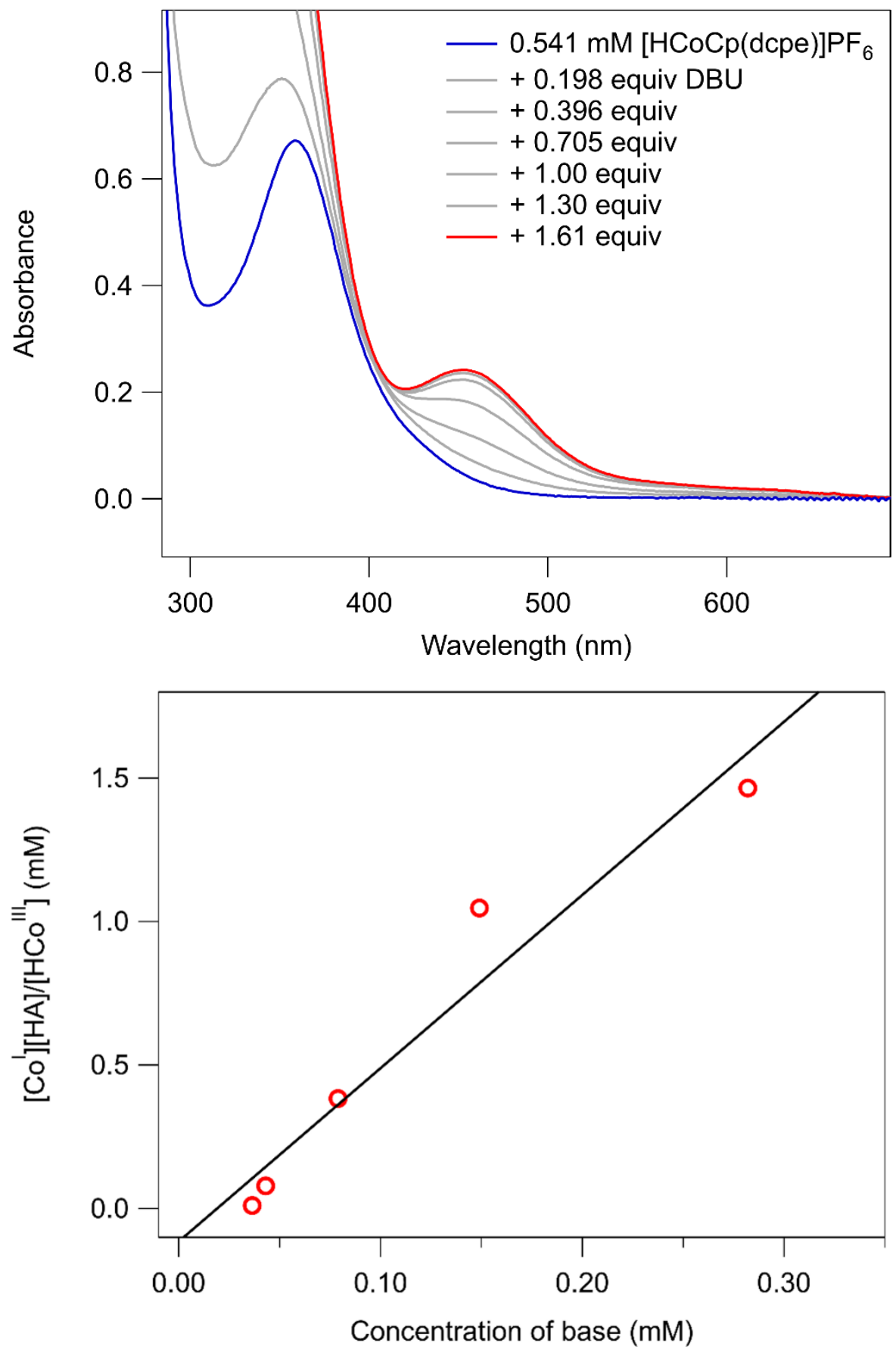

Figure S20. Spectrophotometric titration in $5 \%$ toluene in $\mathrm{CH}_{3} \mathrm{CN}$ starting with $0.54 \mathrm{mM}$ $[\mathrm{HCoCp}(\mathrm{dcpe})]\left[\mathrm{PF}_{6}\right](6)$ (blue trace - ) and titrating in increasing amounts of DBU (gray traces). $\mathrm{UV} / \mathrm{vis}$ absorbance spectrum of $0.54 \mathrm{mM} \mathrm{CoCp}(\mathrm{dcpe})$ is shown to indicate end point (red trace -). The absorbance at $462 \mathrm{~nm}$ and the extinction coefficients of $[\mathrm{HCoCp}(\mathrm{dcpe})]\left[\mathrm{PF}_{6}\right]$ and $\mathrm{CoCp}(\mathrm{dcpe})$ were used to calculate concentration of each species as a function of added base. Linear regression of the equation for the acid base equilibrium between the species and the known $\mathrm{p} K_{\mathrm{a}}$ of DBU was used to determine the $\mathrm{p} K_{\mathrm{a}}$ of $[\mathrm{HCoCp}(\mathrm{dcpe})]\left[\mathrm{PF}_{6}\right]$ as 22.6 . 


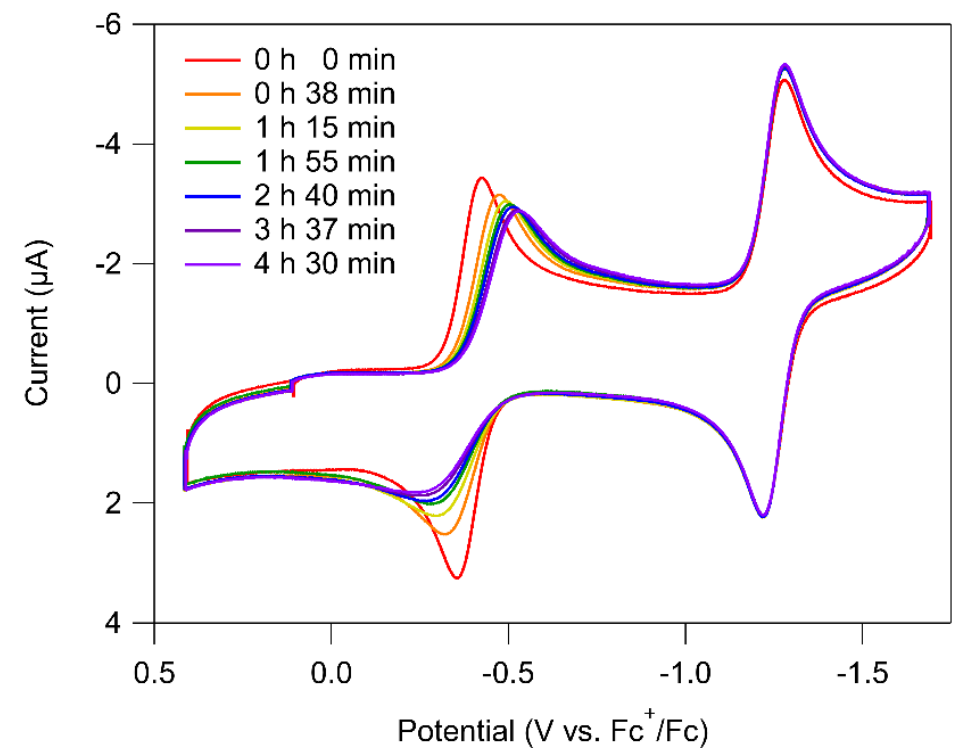

Figure S21. Cyclic voltammograms of $\mathbf{3}$ at various time delays after dissolution in $0.25 \mathrm{M}$ $\left[\mathrm{Bu}_{4} \mathrm{~N}\right]\left[\mathrm{PF}_{6}\right] \mathrm{CH}_{3} \mathrm{CN}$ solution recorded at $\mathrm{v}=$ of $100 \mathrm{mV} / \mathrm{s}$. 


\section{Determination of diffusion coefficients}

The discussion coefficient D was determined using the Randles-Sevcik equation:

$$
i_{p}=0.4462 n F A C \sqrt{\frac{n F D}{R T}} \times \sqrt{v}
$$

This equation relates the peak current $i_{\mathrm{p}}$ to the diffusion coefficient $D$, the number of electrons transferred $n$, the surface area of the electrode $A$ ( $3 \mathrm{~mm}$ diameter), the concentration of the analyte $C$, the scan rate $v$ and the temperature $(\mathrm{T}=304 \mathrm{~K})$, gas constant and the Faraday constant. The faradic peak current (corrected for capacitive current) was measured at varying scan rates and plotted versus $v^{1 / 2}$.

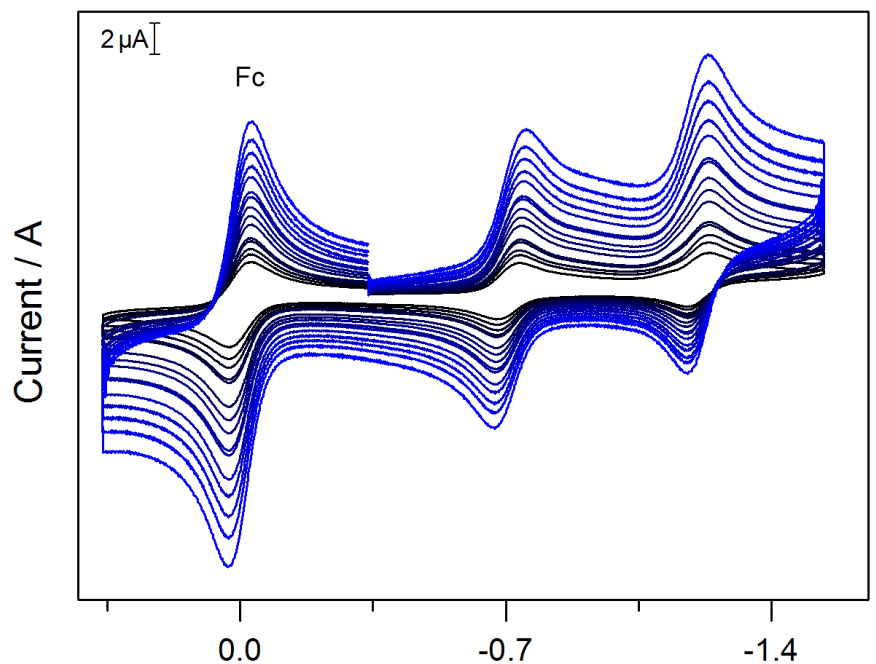

Potential / V vs Fc
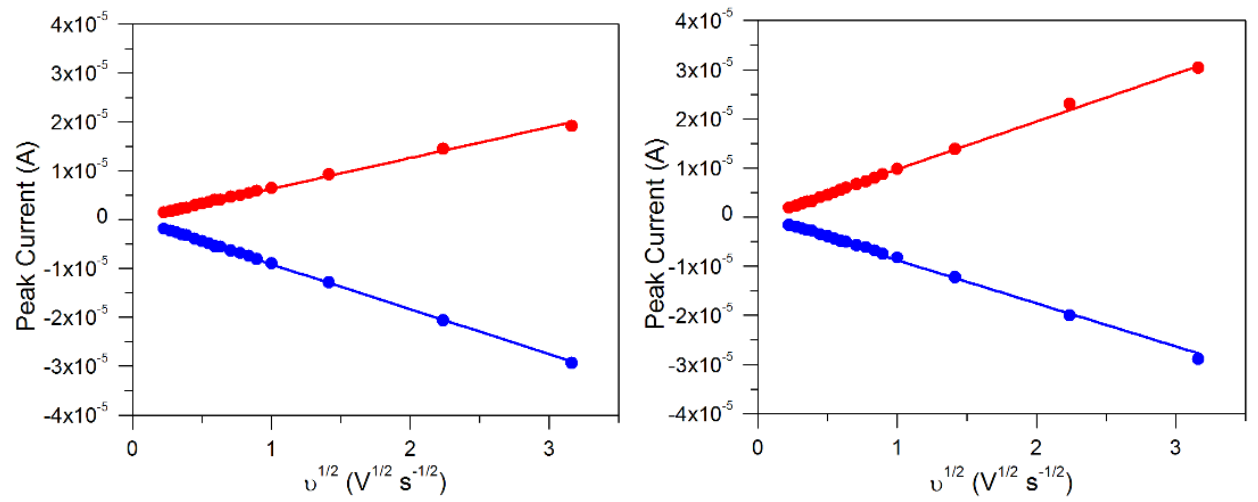

Figure S22. Determination of diffusion coefficients for $\left[\mathrm{CoCp}(\right.$ depe $\left.)\left(\mathrm{NCCH}_{3}\right)\right]\left[\mathrm{PF}_{6}\right]_{2}(\mathbf{2})$. Top: cyclic voltammograms of $0.2 \mathrm{mM}$ of $\left[\mathrm{Co}(\mathrm{Cp})(\mathrm{depe})\left(\mathrm{NCCH}_{3}\right)\right]\left[\mathrm{PF}_{6}\right]_{2}$ in $5 \mathrm{~mL}$ of $\mathrm{CH}_{3} \mathrm{CN}$ with $0.25 \mathrm{M}\left[\mathrm{Bu}_{4} \mathrm{~N}\right]\left[\mathrm{PF}_{6}\right]$ supporting electrolyte were recorded at $0.05,0.075,0.1,0.125,0.15$, $0.2,0.25,0.3,0.35,0.4,0.5,0.6,0.7,0.8$ and $1 \mathrm{~V} / \mathrm{s}$. The $\mathrm{CVs}$ are referenced to the ferrocenium/ferrocene couple at $0 \mathrm{~V}$. Bottom: plots of the peak current (corrected for capacitive current) as a function of $v^{1 / 2}$ for the $\mathrm{Co}$ (III/II) (left) and Co(II/I) (right) couples. From the slopes, an average diffusion coefficient of $4.4 \times 10^{-6} \mathrm{~cm}^{2} / \mathrm{s}$ was calculated from the Co(III/II) wave, and $6.7 \times 10^{-6} \mathrm{~cm}^{2} / \mathrm{s}$ for the $\operatorname{Co}(\mathrm{II} / \mathrm{I})$ wave. 

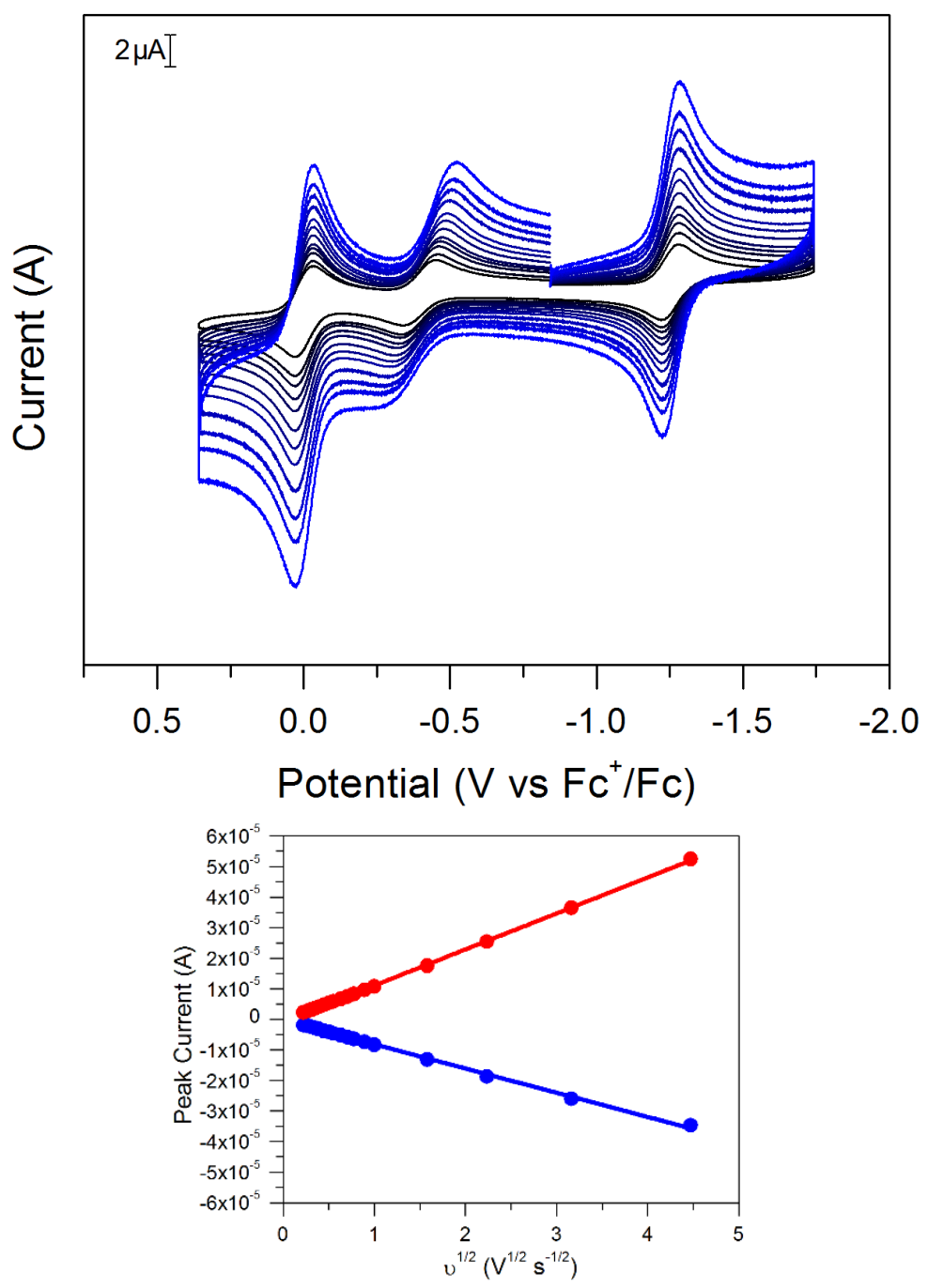

Figure S23. Determination of diffusion coefficients for $\left[\mathrm{CoCp}(\mathrm{dcpe})\left(\mathrm{NCCH}_{3}\right)\right]\left[\mathrm{PF}_{6}\right]_{2}(\mathbf{3})$. Top: cyclic voltammograms of $0.2 \mathrm{mM}$ of $\left[\mathrm{Co}(\mathrm{Cp})(\mathrm{dcpe})\left(\mathrm{NCCH}_{3}\right)\right]\left[\mathrm{PF}_{6}\right]_{2}$ in $5 \mathrm{~mL}$ of $\mathrm{CH}_{3} \mathrm{CN}$ with $0.25 \mathrm{M}\left[\mathrm{Bu}_{4} \mathrm{~N}\right]\left[\mathrm{PF}_{6}\right]$ supporting electrolyte were recorded at $0.05,0.075,0.1,0.125,0.15$, $0.2,0.25,0.3,0.4,0.5,0.6$ and $0.8 \mathrm{~V} / \mathrm{s}$. The $\mathrm{CVs}$ are referenced to the ferrocenium/ferrocene couple at $0 \mathrm{~V}$. Bottom: plot of the peak current (corrected for capacitive current) as a function of $v^{1 / 2}$ for $\mathrm{Co}(\mathrm{II} / \mathrm{I})$ couple. From the slope, an average diffusion coefficient of $7.0 \times 10^{-6} \mathrm{~cm}^{2} / \mathrm{s}$ was calculated for the $\mathrm{Co}(\mathrm{II} / \mathrm{I})$ wave. 


\section{Determination of heterogeneous electron transfer rate constants}

The heterogeneous electron transfer rate constants $\left(k_{\mathrm{s}}\right)$ for $\mathbf{2}$ and $\mathbf{3}$ were determined through trumpet plot analysis as described in detail in the experimental section of reference 1 . Briefly, the analysis relies on the evolution of the peak-to-peak separation as the scan rate $v$ is varied. Uncertainty in the $k_{\mathrm{s}}$ values can arise from both the diffusion coefficient and the trumpet plot analysis itself; we expect most of our uncertainty arises from the latter. Estimated uncertainty in the $\mathrm{x}$-axis offset between the data and the working curves is $+/-0.1$, this gives rise to an estimated error in $k_{\mathrm{s}}$ of $+/-0.003 \mathrm{~cm} / \mathrm{s}$.

Voltammograms used for this analysis are presented in Figures S22 and S23.

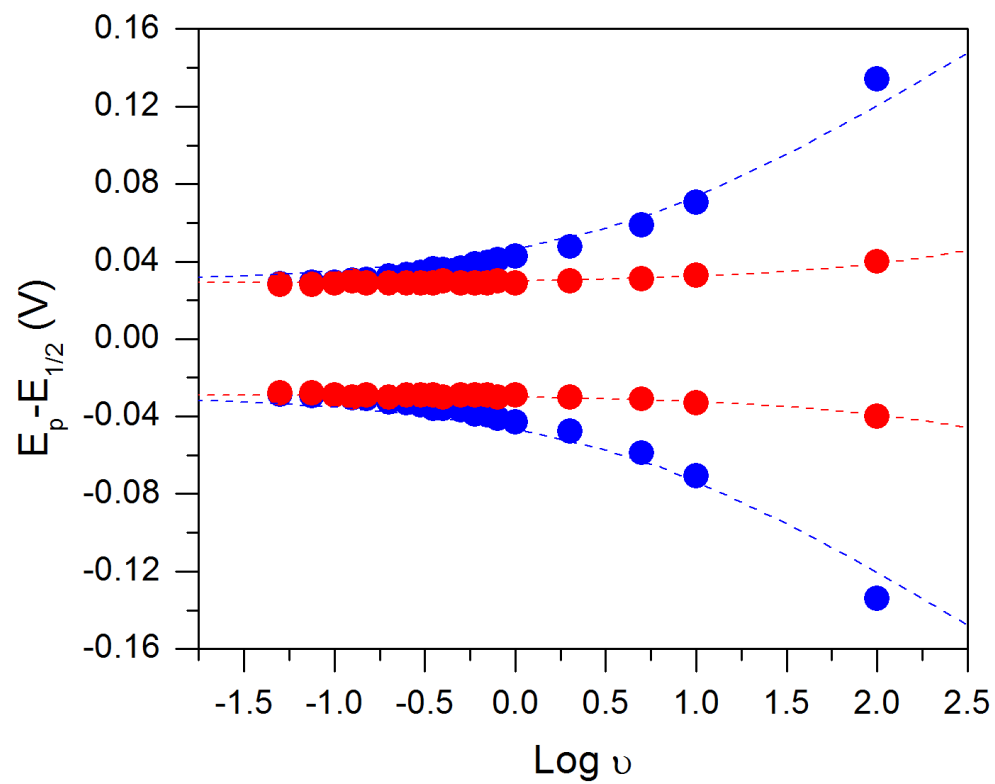

Figure S24. Determination of heterogeneous electron transfer rate constants for $\left[\mathrm{CoCp}\left(\right.\right.$ depe) $\left.\left(\mathrm{NCCH}_{3}\right)\right]\left[\mathrm{PF}_{6}\right]_{2}$ (2). Trumpet plot of the $\mathrm{Co}(\mathrm{III} / \mathrm{II})$ (blue circles) and $\mathrm{Co}(\mathrm{II} / \mathrm{I})$ (red circles) waves overlaid with the working curve (dashed curves). The working curves used the parameters $\mathrm{D}=1 \times 10^{-5} \mathrm{~cm}^{2} / \mathrm{s}$ and $k_{\mathrm{s}}=1 \mathrm{~cm} / \mathrm{s}$. The offset $(\Delta)$ between the data and the $\mathrm{x}$-axis of the best fitting working curve is used to determine $k_{\mathrm{s}}$. The obtained $k_{\mathrm{s}}$ are $0.022 \mathrm{~cm} / \mathrm{s}(\Delta=3.1)$ and $0.36 \mathrm{~cm} / \mathrm{s}(\Delta=-0.7)$ for the $\mathrm{Co}(\mathrm{III} / \mathrm{II})$ and $\mathrm{Co}(\mathrm{II} / \mathrm{I})$ wave, respectively. 


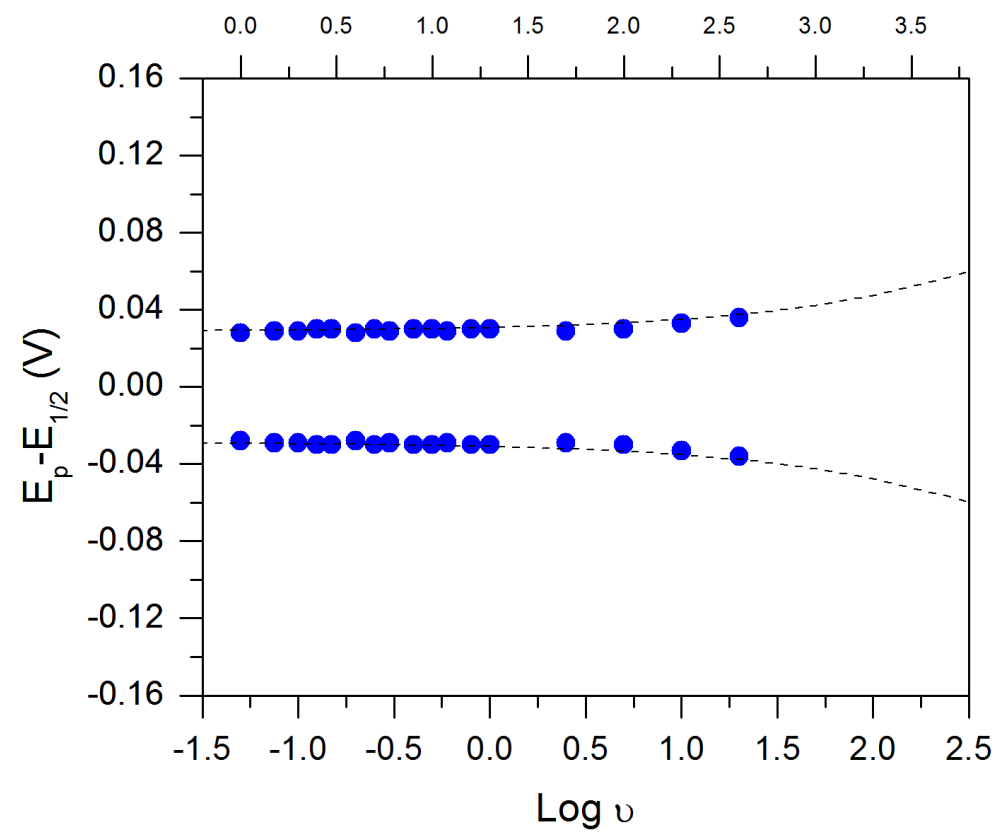

Figure S25. Determination of heterogeneous electron transfer rate constant for $\left[\mathrm{CoCp}(\mathrm{dcpe})\left(\mathrm{NCCH}_{3}\right)\right]\left[\mathrm{PF}_{6}\right]_{2}(3)$. Trumpet plot of the $\mathrm{Co}(\mathrm{II} / \mathrm{I})$ waves overlaid with the working curve (dashed curves). The working curves used the parameters $\mathrm{D}=1 \times 10^{-5} \mathrm{~cm}^{2} / \mathrm{s}$ and $k_{\mathrm{s}}=1 \mathrm{~cm} / \mathrm{s}$. The offset $(\Delta)$ between the data and the $\mathrm{x}$-axis of the best fitting working curve is used to determine $k_{\mathrm{s}}$. The obtained $k_{\mathrm{s}}$ is $0.19 \mathrm{~cm} / \mathrm{s}(\Delta=1.3)$ for the $\mathrm{Co}(\mathrm{II} / \mathrm{I})$ wave.

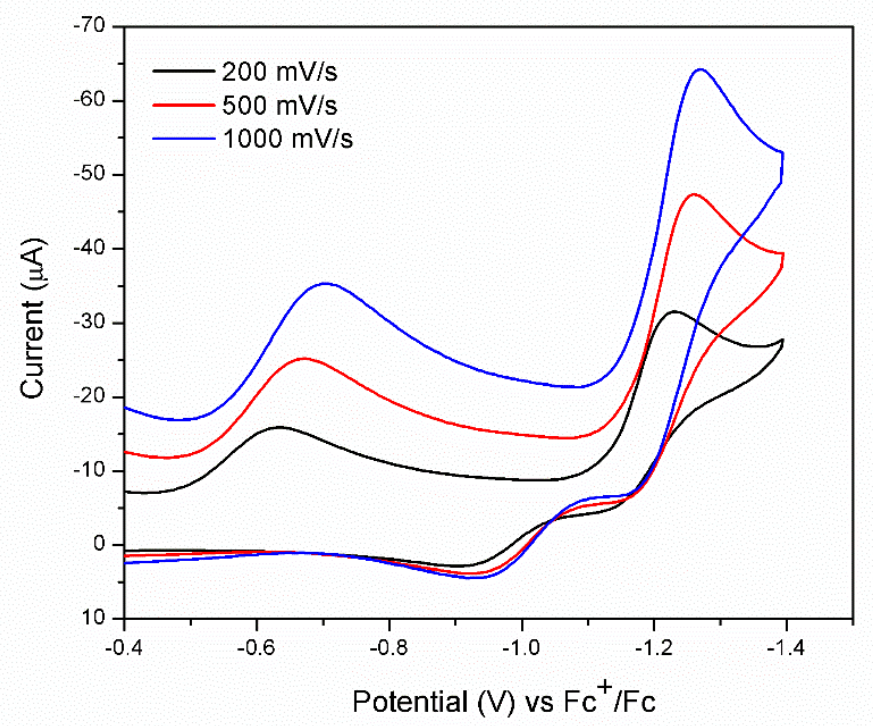

Figure S26. Illustrative CVs of $2(1 \mathrm{mM})$ in $0.25 \mathrm{M}\left[\mathrm{Bu}_{4} \mathrm{~N}\right]\left[\mathrm{PF}_{6}\right]$ in $\mathrm{CH}_{2} \mathrm{Cl}_{2}$ at different scan rates. In these data, neither the $\mathrm{Co}(\mathrm{III} / \mathrm{II})$ nor the $\mathrm{Co}(\mathrm{II} / \mathrm{I})$ couples are reversible, suggesting redoxinitiated reactivity, likely with the solvent. 

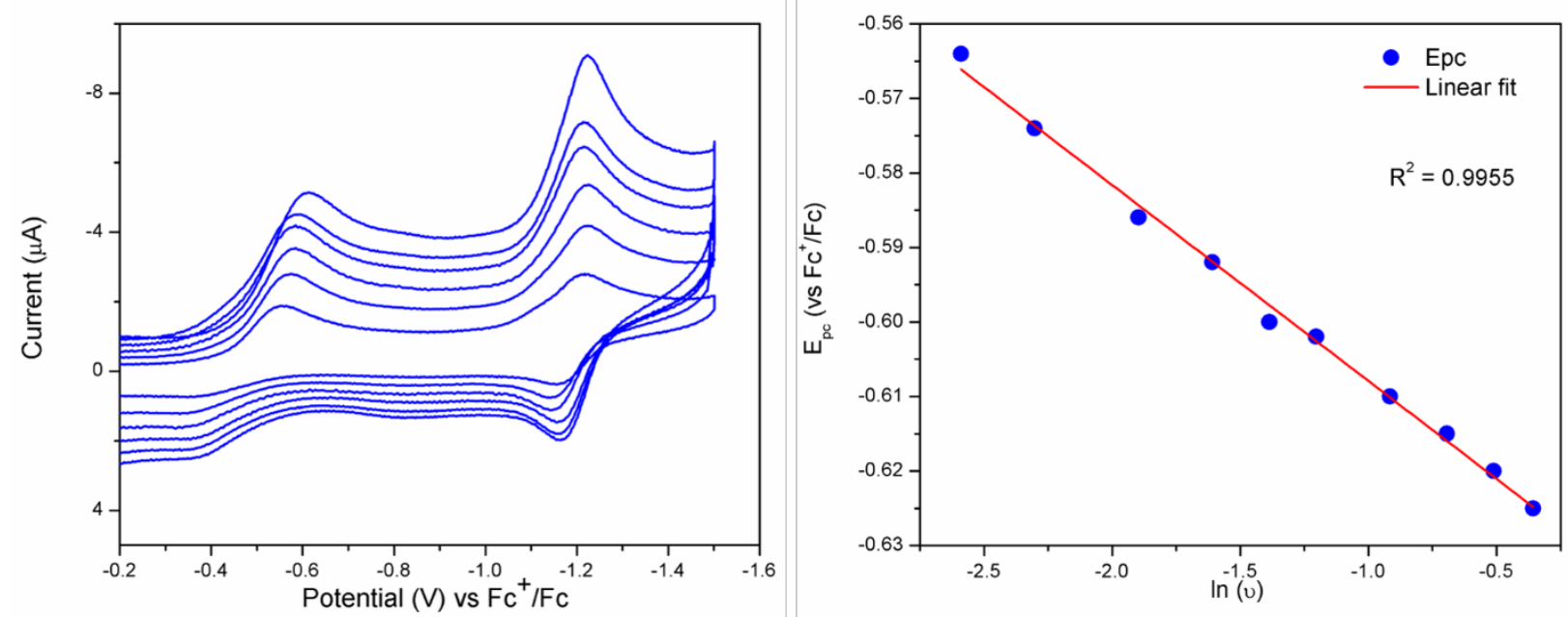

Figure S27. Illustrative CVs of $2(0.2 \mathrm{mM})$ in $0.25 \mathrm{M}\left[\mathrm{Bu}_{4} \mathrm{~N}\right]\left[\mathrm{PF}_{6}\right]$ in DFB at different scan rates $(100-600 \mathrm{mV} / \mathrm{s})$ and plot of $\mathrm{E}_{\mathrm{pc}} \mathrm{vs} \ln (\mathrm{v})$, used to determine the rate of $\mathrm{CH}_{3} \mathrm{CN}$ dissociation $\left(k_{\mathrm{d}}\right.$, Equation 1).
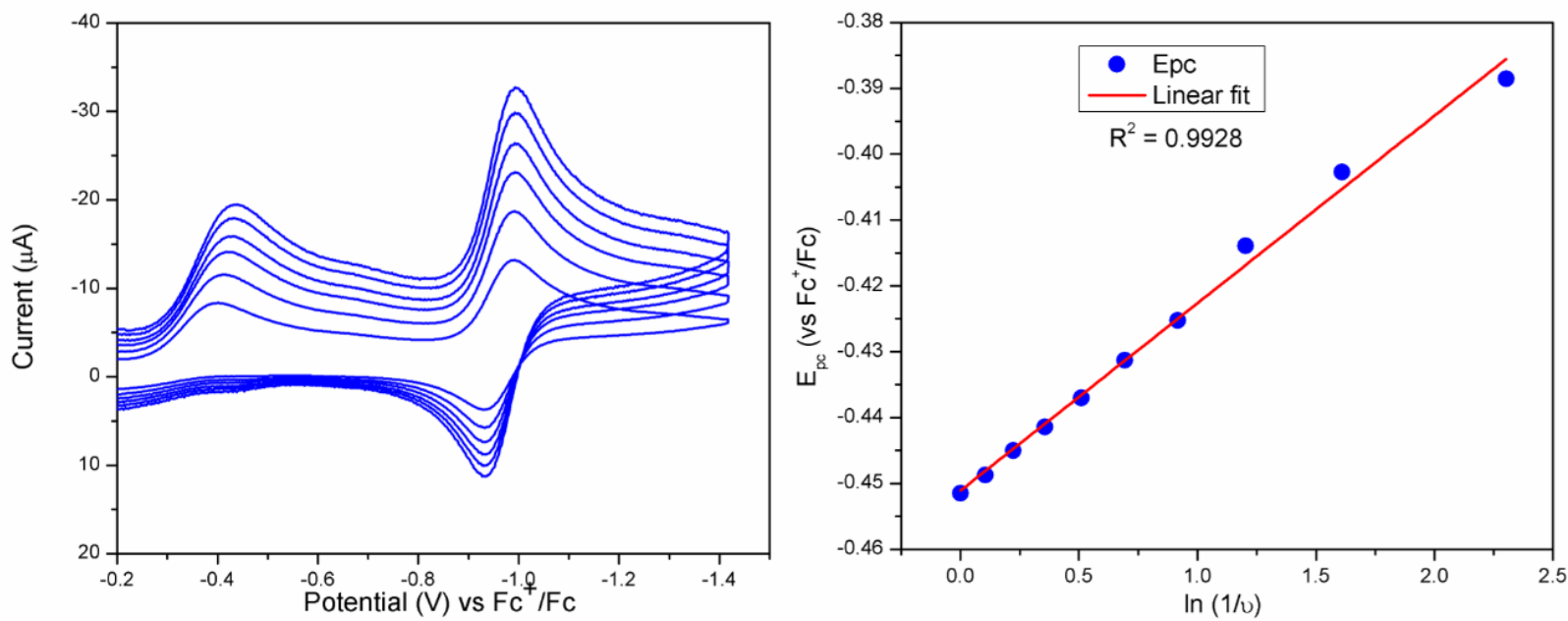

Figure S28. Illustrative CVs of $1(1 \mathrm{mM})$ in $0.25 \mathrm{M}\left[\mathrm{Bu}_{4} \mathrm{~N}\right]\left[\mathrm{PF}_{6}\right]$ in DFB at different scan rates $(100-600 \mathrm{mV} / \mathrm{s})$ and plot of $\mathrm{E}_{\mathrm{pc}} \mathrm{Vs} \ln (1 / \mathrm{v})$, used to determine the rate of $\mathrm{CH}_{3} \mathrm{CN}$ dissociation $\left(k_{\mathrm{d}}\right.$, Equation 1). 

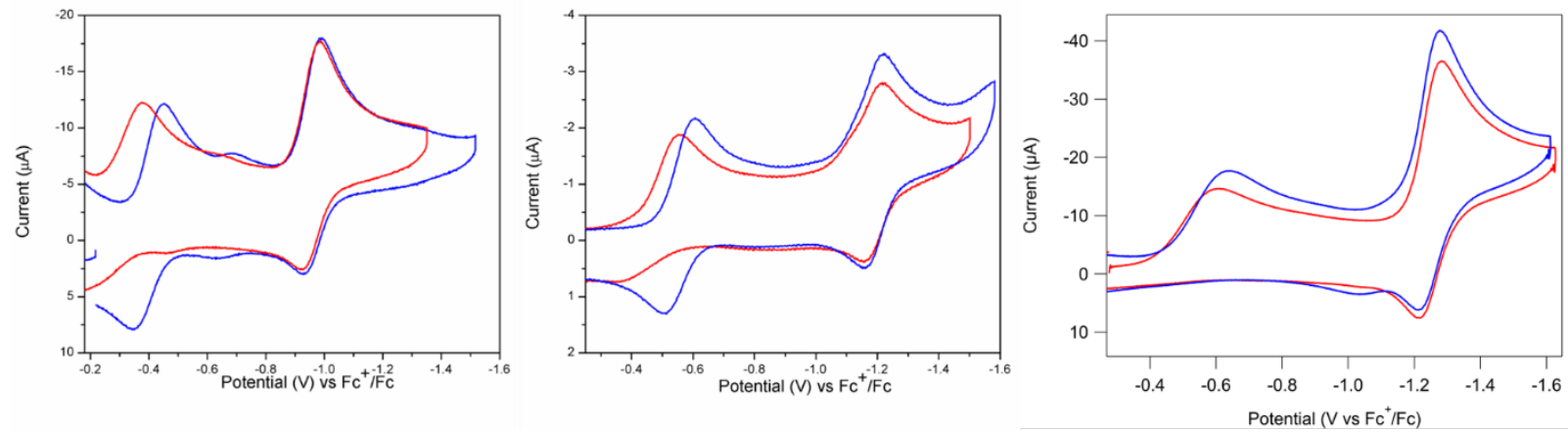

Figure S29. (Left) Illustrative CVs of $1(1 \mathrm{mM})$ in $0.25 \mathrm{M}\left[\mathrm{Bu}_{4} \mathrm{~N}\right]\left[\mathrm{PF}_{6}\right]$ in DFB at a scan rate of $100 \mathrm{mV} / \mathrm{s}$, recorded in the absence (red trace) and presence of excess $\mathrm{CH}_{3} \mathrm{CN}$ (blue trace). (Middle) Illustrative CVs of and $2(0.2 \mathrm{mM})$ in $0.25 \mathrm{M}\left[\mathrm{Bu}_{4} \mathrm{~N}\right]\left[\mathrm{PF}_{6}\right]$ in DFB at a scan rate of 100 $\mathrm{mV} / \mathrm{s}$, recorded in the absence (red trace) and presence of excess $\mathrm{CH}_{3} \mathrm{CN}$ (blue trace). (Right) Illustrative $\mathrm{CVs}$ of and 3 in $0.25 \mathrm{M}\left[\mathrm{Bu}_{4} \mathrm{~N}\right]\left[\mathrm{PF}_{6}\right]$ in DFB at a scan rate of $1000 \mathrm{mV} / \mathrm{s}$, recorded in the absence (red trace) and presence of excess $\mathrm{CH}_{3} \mathrm{CN}$ (blue trace).
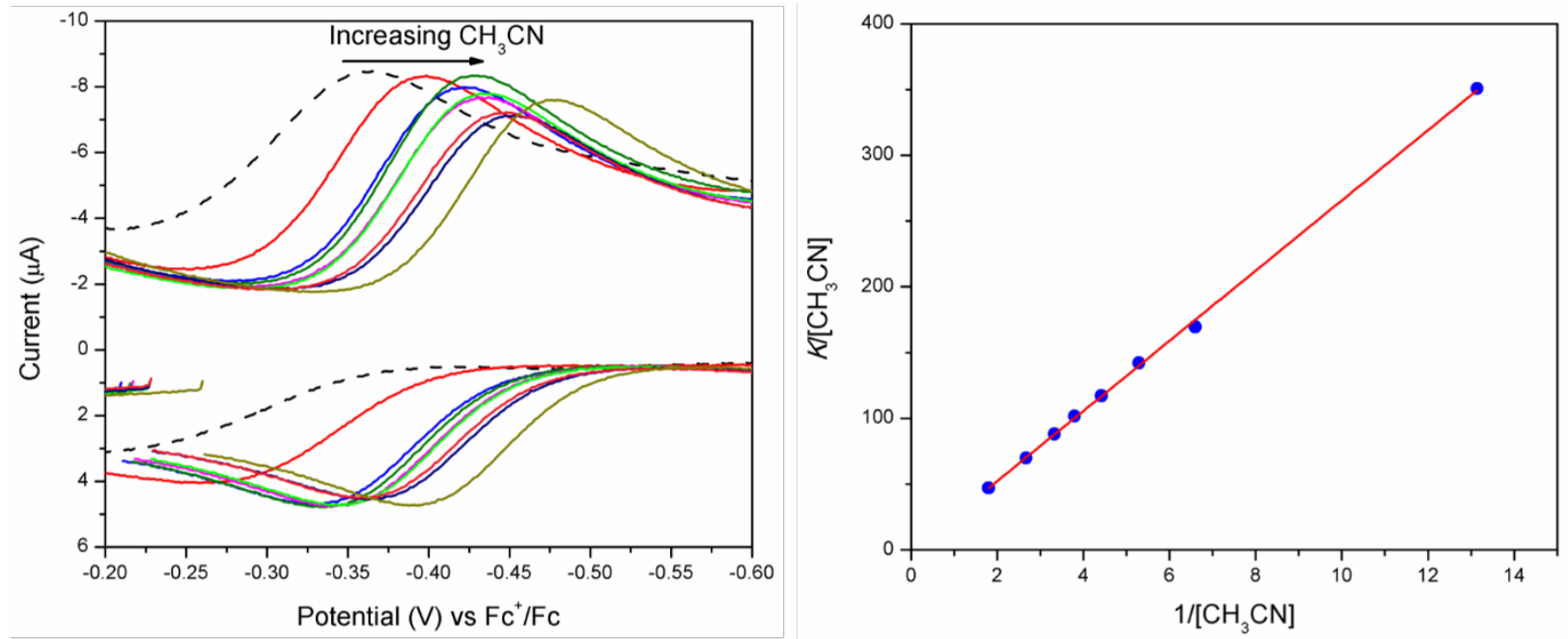

Figure S30. (Left) CVs of $1(0.5 \mathrm{mM})$ in $0.25 \mathrm{M}\left[\mathrm{Bu}_{4} \mathrm{~N}\right]\left[\mathrm{PF}_{6}\right]$ in DFB recorded at a scan rate of $200 \mathrm{mV} / \mathrm{s}$ with increasing amounts of $\mathrm{CH}_{3} \mathrm{CN}$, with the $\mathrm{CV}$ in absence of any titrated $\mathrm{CH}_{3} \mathrm{CN}$ depicted by the black dashed trace. (Right) Plot of $K_{\text {eq }} /\left[\mathrm{CH}_{3} \mathrm{CN}\right]$ vs $1 /\left[\mathrm{CH}_{3} \mathrm{CN}\right]$ determined from the CVs using the equation $E^{o}=E_{1 / 2}+\mathrm{RT} / \mathrm{F} \ln \left(1+K_{\mathrm{eq}} /\left[\mathrm{CH}_{3} \mathrm{CN}\right]\right)$. The slope of the linear fit provides $K_{\mathrm{eq}}(25 \pm 1 \mathrm{M})$. 

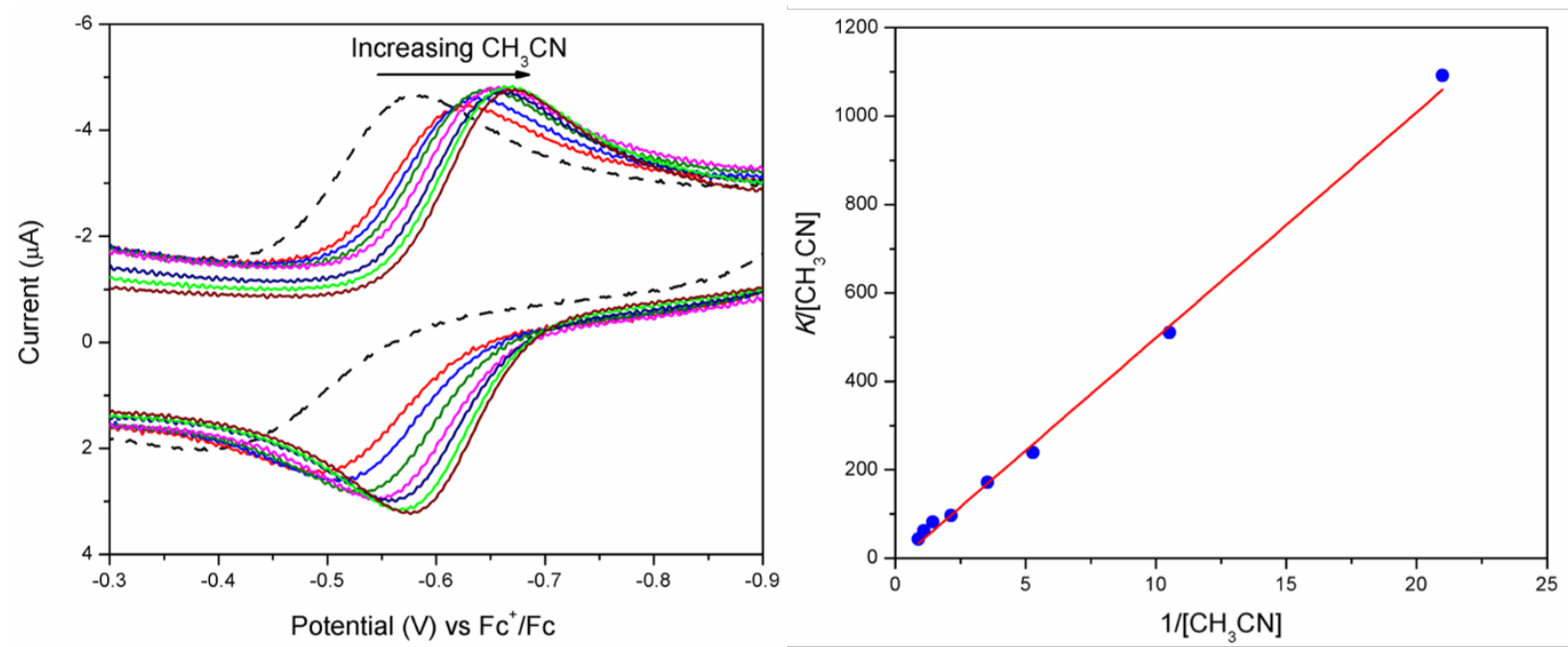

Figure S31. (Left) CVs of $2(0.5 \mathrm{mM})$ in $0.25 \mathrm{M}\left[\mathrm{Bu}_{4} \mathrm{~N}\right]\left[\mathrm{PF}_{6}\right]$ in DFB recorded at a scan rate of $500 \mathrm{mV} / \mathrm{s}$ with increasing amounts of $\mathrm{CH}_{3} \mathrm{CN}$, with the $\mathrm{CV}$ in absence of any titrated $\mathrm{CH}_{3} \mathrm{CN}$ depicted by the black dashed trace. (Right) Plot of $\mathrm{K}_{\mathrm{eq}} /\left[\mathrm{CH}_{3} \mathrm{CN}\right]$ vs $1 /\left[\mathrm{CH}_{3} \mathrm{CN}\right]$ determined from the CVs using the equation $E^{o}=E_{1 / 2}+\mathrm{RT} / \mathrm{F} \ln \left(1+K_{\mathrm{eq}} /\left[\mathrm{CH}_{3} \mathrm{CN}\right]\right)$. The slope of the linear fit provides $K_{\text {eq }}(50 \pm 1 \mathrm{M})$.
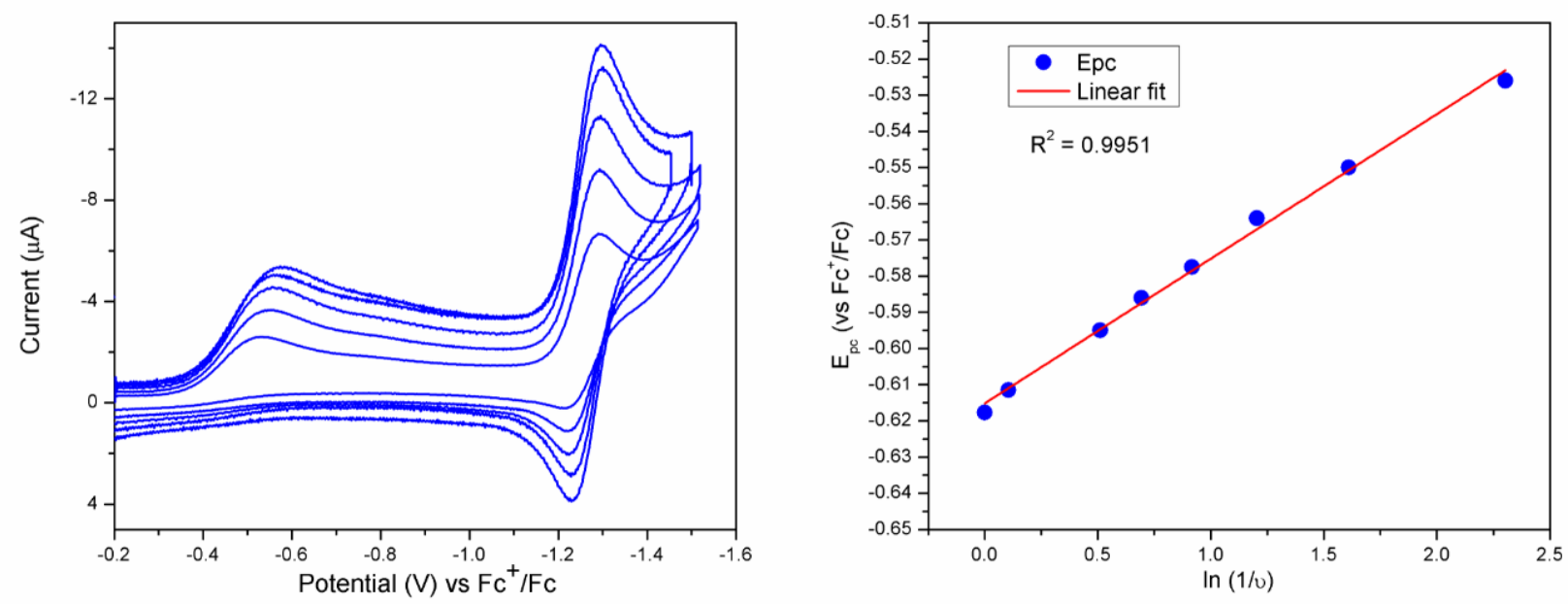

Figure S32. Illustrative $\mathrm{CVs}$ of $\mathbf{3}(0.5 \mathrm{mM})$ in $0.25 \mathrm{M}[\mathrm{Bu} 4 \mathrm{~N}]\left[\mathrm{PF}_{6}\right]$ in $\mathrm{CH}_{2} \mathrm{Cl}_{2}$ at different scan rates $(100-500 \mathrm{mV} / \mathrm{s})$ and plot of $\mathrm{E}_{\mathrm{pc}} \mathrm{vs} \ln (1 / \mathrm{v})$, which is used to determine the rate ${ } \mathrm{CH}_{3} \mathrm{CN}$ dissociation. Here, due to the fact that the true, reversible $E_{1 / 2}$ of the $\mathrm{Co}(\mathrm{III} / \mathrm{II})$ redox feature for 3 is not accessible, the $E_{1 / 2}$ for the $\mathrm{Co}(\mathrm{III} / \mathrm{II})$ feature of 2 was used in the determination of $k_{\mathrm{d}}$ (as described in the main text using equation 1). 
Table S1. Computed free energies and $K_{\mathrm{eq}}$ for acetonitrile dissociation from $\left[\mathrm{CoCp}(\mathrm{dcpe})\left(\mathrm{NCCH}_{3}\right)\right]^{+}$and $\left[\mathrm{CoCp}(\mathrm{dcpe})\left(\mathrm{NCCH}_{3}\right)\right]^{2+}$.

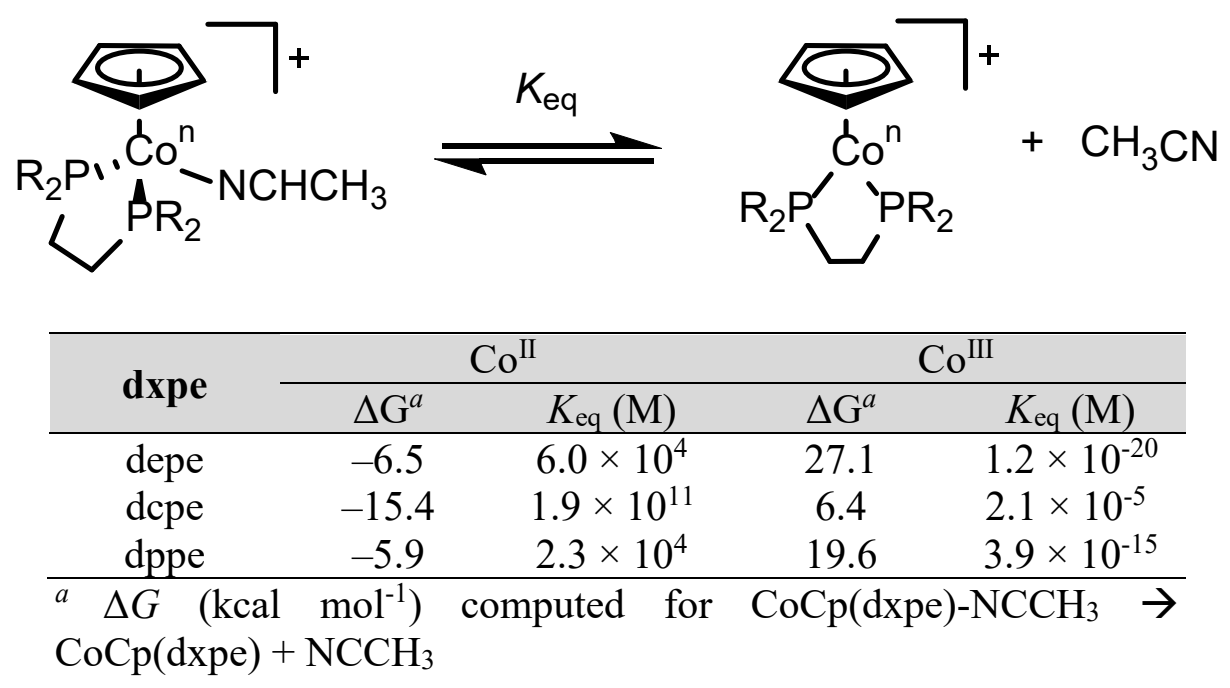

Table S2. Summary of apparent proton transfer rate constants of $\mathrm{CoCp}(\mathrm{depe})$ utilizing different non-bulky acids with varying $\mathrm{p} K_{\mathrm{a}}$ values.

\begin{tabular}{|c|c|c|}
\hline Acid & $\mathrm{p} K_{\mathrm{a}}$ of acid & $k_{P T}^{a p p}\left(\mathbf{M}^{-1} \mathbf{s}^{-1}\right)$ \\
\hline phenol & 29.14 & $8.7 \times 10^{3}$ \\
\hline 4-CH 3 -phenol & 27.5 & $1.8 \times 10^{4}$ \\
\hline phenol & 26.6 & $8.7 \times 10^{3}$ \\
\hline 4-CF - -phenol & 25.54 & $7.0 \times 10^{5}$ \\
\hline 4-Cl-phenol & 25.44 & $1.2 \times 10^{5}$ \\
\hline 4-CF 3 -phenol & 24.9 & $7.0 \times 10^{5}$ \\
\hline acetic acid & 23.51 & $5.6 \times 10^{6}$ \\
\hline benzoic acid & 21.51 & $3.6 \times 10^{7}$ \\
\hline 2,3,5,6-tetrafluorophenol & 20.12 & $4.4 \times 10^{7}$ \\
\hline benzylammonium tetrafluoroborate & 16.91 & $3.8 \times 10^{7}$ \\
\hline salicylic acid & 16.7 & $5.6 \times 10^{7}$ \\
\hline 4- $\mathrm{CH}_{3} \mathrm{O}$-pyridinium tetrafluoroborate & 14.23 & $3.2 \times 10^{7}$ \\
\hline pyridinium tetrafluoroborate & 12.53 & $3.5 \times 10^{7}$ \\
\hline 4- $\mathrm{CH}_{3}$-anilinium tetrafluoroborate & 11.4 & $3.6 \times 10^{7}$ \\
\hline 4- ${ }^{t} \mathrm{Bu}$-anilinium tetrafluoroborate & 11.1 & $2.9 \times 10^{7}$ \\
\hline 4-Cl-anilinium tetrafluoroborate & 9.7 & $4.5 \times 10^{7}$ \\
\hline 4- $\mathrm{CF}_{3} \mathrm{O}$-anilinium tetrafluoroborate & 9.28 & $3.2 \times 10^{7}$ \\
\hline 4-CN-anilinium tetrafluoroborate & 7 & $1.5 \times 10^{7}$ \\
\hline
\end{tabular}


Table S3. Summary of apparent proton transfer rate constants of $\mathrm{CoCp}(\mathrm{dcpe})$ utilizing different non-bulky acids with varying $\mathrm{p} K_{\mathrm{a}}$ values.

\begin{tabular}{|c|c|c|}
\hline Acid & $\mathrm{p} K_{\mathrm{a}}$ of acid & $k_{P T}^{\alpha p p}\left(\mathbf{M}^{-1} \mathrm{~s}^{-1}\right)$ \\
\hline 4-Cl-phenol & 25.44 & $2.60 \times 10^{2}$ \\
\hline acetic acid & 23.51 & $8.20 \times 10^{3}$ \\
\hline 2,3,5,6-tetrafluorophenol & 20.12 & $8.20 \times 10^{4}$ \\
\hline 2,3,4,5,6-pentaphenol & 20.11 & $1.10 \times 10^{5}$ \\
\hline 2,3,5,6-tetrafluoro-4-CF 3 -phenol & 16.62 & $1.30 \times 10^{5}$ \\
\hline 4- $\mathrm{CH}_{3} \mathrm{O}$-pyridinium tetrafluoroborate & 14.23 & $5.30 \times 10^{4}$ \\
\hline pyridinium tetrafluoroborate & 12.53 & $5.90 \times 10^{4}$ \\
\hline 4- ${ }^{t} \mathrm{Bu}$-anilinium tetrafluoroborate & 11.1 & $5.20 \times 10^{4}$ \\
\hline anilinium tetrafluoroborate & 10.62 & $4.90 \times 10^{4}$ \\
\hline 4-Br-anilinium tetrafluoroborate & 9.43 & $6.60 \times 10^{4}$ \\
\hline
\end{tabular}

Table S4. Summary of apparent proton transfer rate constants of CoCp(dppe), CoCp(depe), and CoCp(dcpe) using bulky acids with varying $\mathrm{p} K_{\mathrm{a}}$ values.

\begin{tabular}{ccccc}
\hline Acid & $\mathbf{p} \boldsymbol{K}_{\mathbf{a}}$ of acid & \multicolumn{3}{c}{$\left.\boldsymbol{k}_{\boldsymbol{P T}}^{\mathbf{a p p}} \mathbf{( M}^{\mathbf{- 1}} \mathbf{s}^{\mathbf{- 1}}\right)$} \\
\cline { 3 - 5 } & 11.8 & $1.4 \times 10^{4}$ & $6.4 \times 10^{5}$ & $1.2 \times 10^{3}$ \\
\hline $\begin{array}{c}\text { 4-Cl-2,6-dimethylpyridinium } \\
\text { tetrafluoroborate }\end{array}$ & 14.13 & $9.6 \times 10^{3}$ & $3.1 \times 10^{5}$ & $2.2 \times 10^{2}$ \\
\hline $\begin{array}{c}\text { 2,6-dimethylpyridinium } \\
\text { tetrafluoroborate }\end{array}$ & 14.98 & $4.5 \times 10^{3}$ & $6.5 \times 10^{4}$ & $3.7 \times 10^{1}$ \\
\hline $\begin{array}{c}\text { 2,4,6-trimethylpyridinium } \\
\text { tetrafluoroborate }\end{array}$ & 18.5 & $1.8 \times 10^{3}$ & $5.7 \times 10^{4}$ & $2.5 \times 10^{2}$ \\
\hline $\begin{array}{c}\text { 4-NH2-2,6- } \\
\text { dimethylpyridinium } \\
\text { tetrafluoroborate }\end{array}$ & & & \\
\hline
\end{tabular}



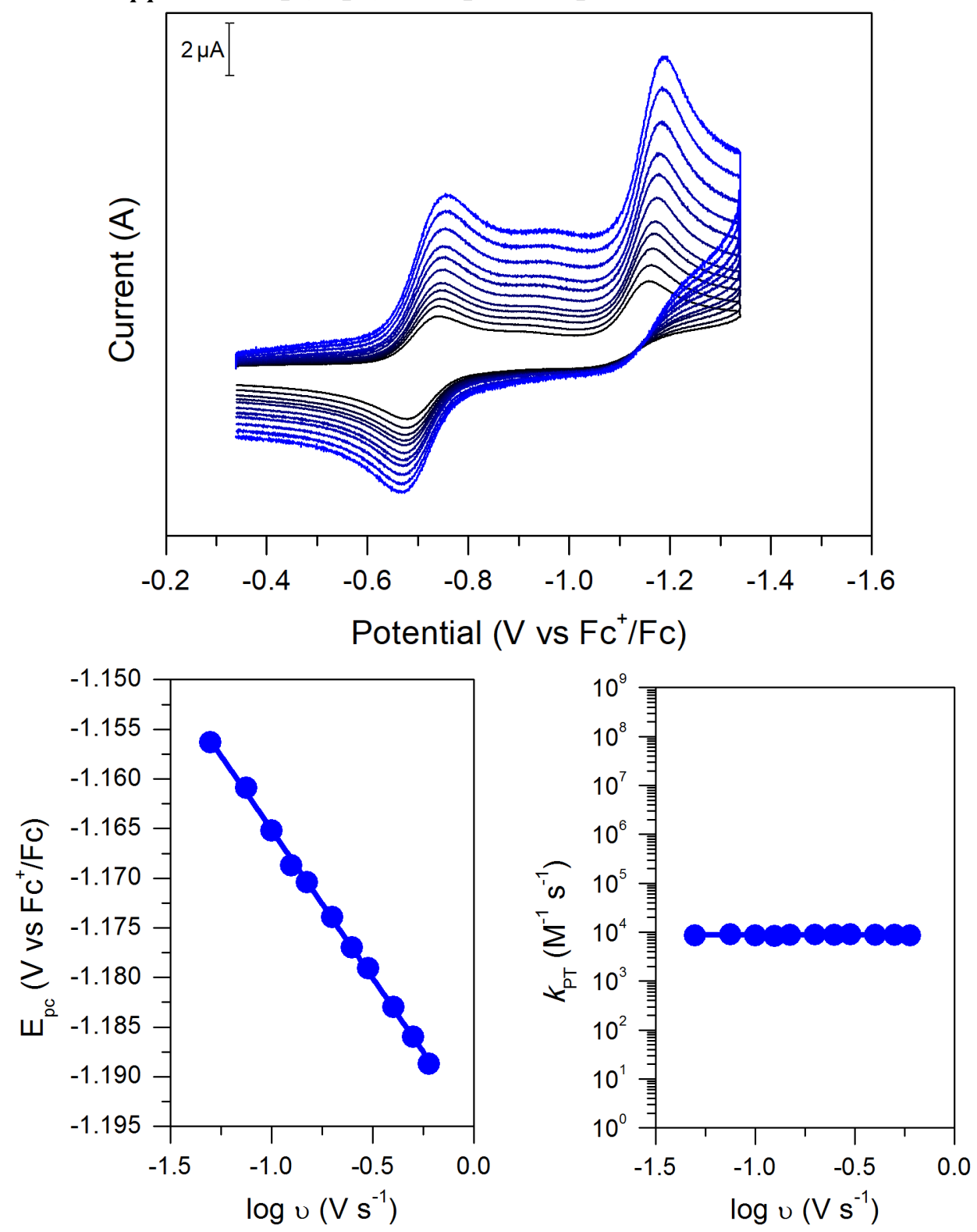

Figure S33. Determination of $\boldsymbol{k}_{\boldsymbol{P T}}^{\boldsymbol{a p p}}$ of CoCp(depe) with phenol.

Top: cyclic voltammograms of $0.2 \mathrm{mM}\left[\mathrm{CoCp}(\right.$ depe $\left.)\left(\mathrm{NCCH}_{3}\right)\right]\left[\mathrm{PF}_{6}\right]_{2}$ in $5 \mathrm{~mL}$ of $\mathrm{CH}_{3} \mathrm{CN}$ with 0.25 $\mathrm{M}\left[\mathrm{Bu}_{4} \mathrm{~N}\right]\left[\mathrm{PF}_{6}\right]$ as supporting electrolyte in the presence of $0.047 \mathrm{M}$ of acid at multiple scan rates $(50,75,100,125,150,200,250,300,400,500$ and $600 \mathrm{mV} / \mathrm{s}$ from black to blue). The CVs are referenced to the ferrocenium/ferrocene couple at $0 \mathrm{~V}$.

Bottom left: evolution of the cathodic peak potential of the Co(II/I) wave $\left(E_{\mathrm{p}, \mathrm{c}}\right)$ with scan rate $(\mathrm{U})$. The slope is $-30 \mathrm{mV} / \mathrm{dec}$, with $\mathrm{R}^{2}=0.999$.

Bottom right: evolution of the obtained $k_{\mathrm{PT}}$ at each scan rate with scan rate. The average yields:

$\boldsymbol{k}_{\boldsymbol{P T}}^{\boldsymbol{a p p}}=8.7 \times 10^{3} \mathrm{M}^{-1} \mathrm{~s}^{-1}$ 


\section{Determination of $\boldsymbol{k}_{P T}^{a p p}$ of $\mathrm{CoCp}\left(\right.$ depe) with 4-CH3-phenol (pKa of 27.5 in $\left.\mathrm{CH}_{3} \mathrm{CN}\right)$}
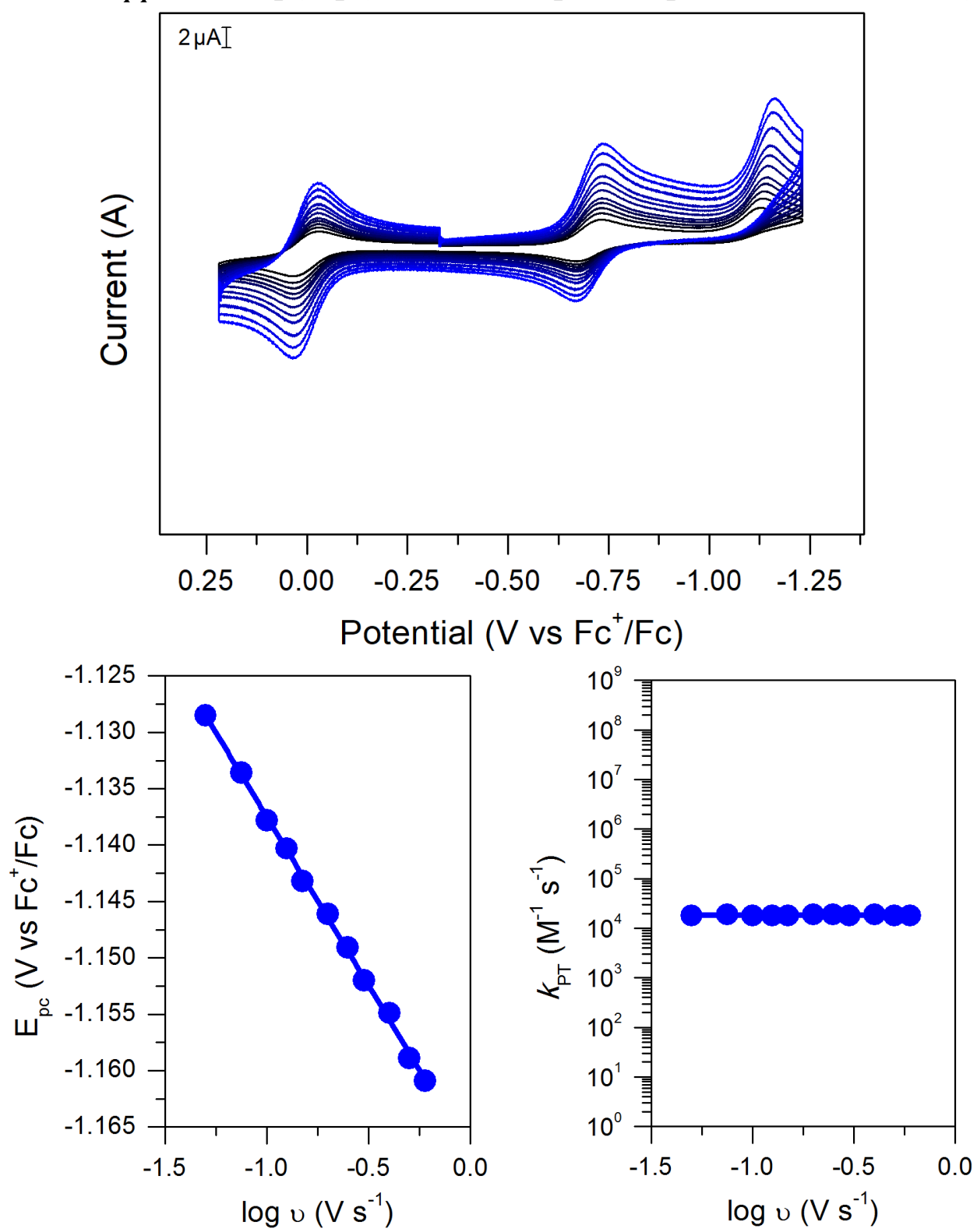

Figure S34. Determination of $\boldsymbol{k}_{\boldsymbol{P T}}^{\boldsymbol{a p p}}$ of $\mathrm{CoCp}(\mathrm{depe})$ with 4- $\mathrm{CH}_{3}-\mathrm{phenol}$

Top: cyclic voltammograms of $0.2 \mathrm{mM}\left[\mathrm{CoCp}(\right.$ depe $\left.)\left(\mathrm{NCCH}_{3}\right)\right]\left[\mathrm{PF}_{6}\right]_{2}$ in $5 \mathrm{~mL}$ of $\mathrm{CH}_{3} \mathrm{CN}$ with 0.25 $\mathrm{M}\left[\mathrm{Bu}_{4} \mathrm{~N}\right]\left[\mathrm{PF}_{6}\right]$ as supporting electrolyte in the presence of $0.234 \mathrm{M}$ of acid at multiple scan rates $(50,75,100,125,150,200,250,300,400,500$ and $600 \mathrm{mV} / \mathrm{s}$ from black to blue). The CVs are referenced to the ferrocenium/ferrocene couple at $0 \mathrm{~V}$.

Bottom left: evolution of the cathodic peak potential of the $\mathrm{Co}(\mathrm{II} / \mathrm{I})$ wave $\left(E_{\mathrm{p}, \mathrm{c}}\right)$ with scan rate $(\mathrm{v})$. The slope is $-30 \mathrm{mV} / \mathrm{dec}$, with $\mathrm{R}^{2}=0.999$.

Bottom right: evolution of the obtained $k_{\mathrm{PT}}$ at each scan rate with scan rate. The average yields: $\boldsymbol{k}_{\boldsymbol{P T}}^{\boldsymbol{a p p}}=1.8 \times 10^{4} \mathrm{M}^{-1} \mathrm{~s}^{-1}$ 

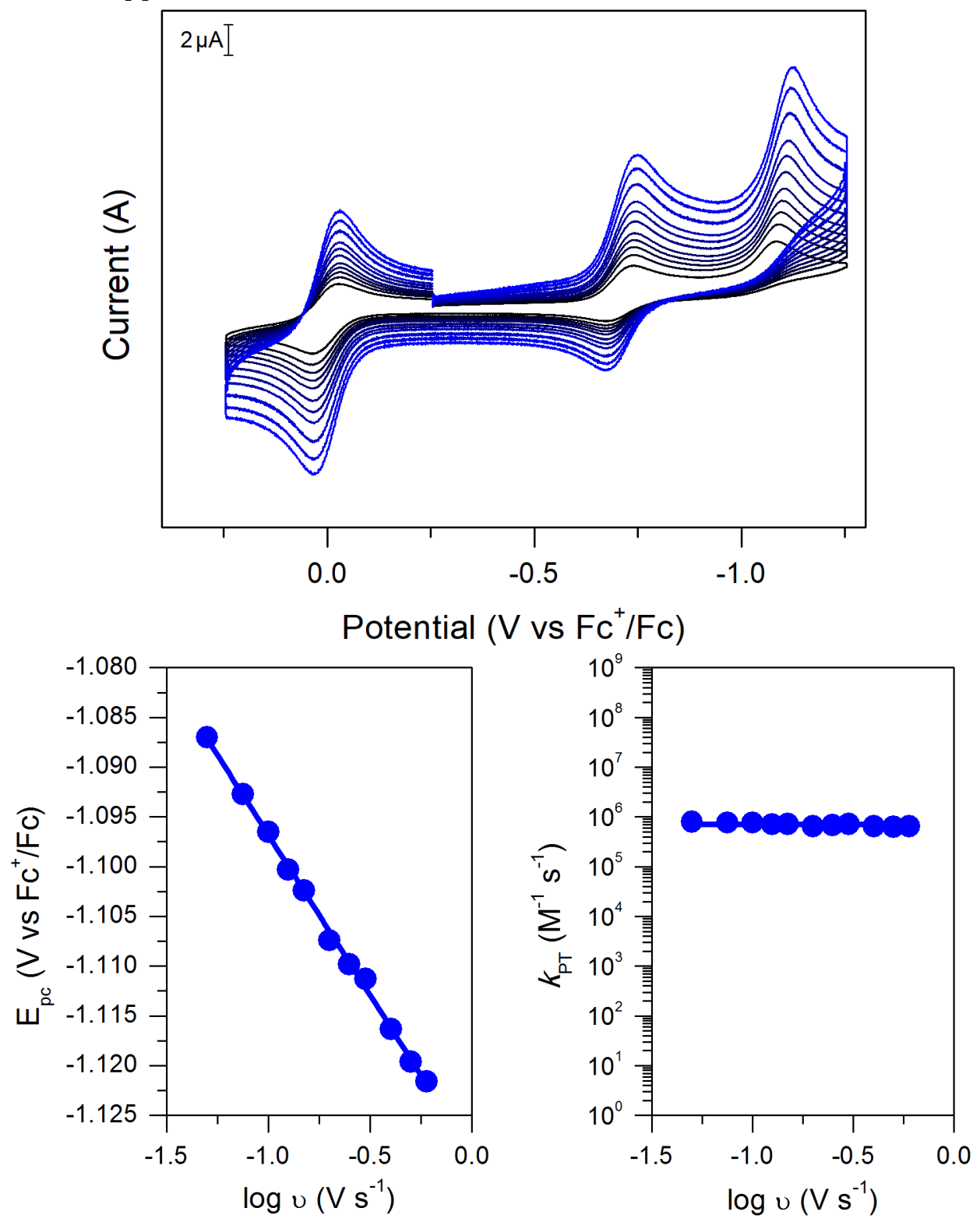

Figure S35. Determination of $\boldsymbol{k}_{\boldsymbol{P T}}^{\boldsymbol{a p p}}$ of $\mathrm{CoCp}(\mathrm{depe})$ with 4-CF $3-$ phenol

Top: cyclic voltammograms of $0.2 \mathrm{mM}\left[\mathrm{CoCp}(\right.$ depe $\left.)\left(\mathrm{NCCH}_{3}\right)\right]\left[\mathrm{PF}_{6}\right]_{2}$ in $5 \mathrm{~mL}$ of $\mathrm{CH}_{3} \mathrm{CN}$ with $0.25 \mathrm{M}\left[\mathrm{Bu}_{4} \mathrm{~N}\right]\left[\mathrm{PF}_{6}\right]$ as supporting electrolyte in the presence of $0.155 \mathrm{M}$ of acid at multiple scan rates $(50,75,100,125,150,200,250,300,400,500$ and $600 \mathrm{mV} / \mathrm{s}$ from black to blue). The CVs are referenced to the ferrocenium/ferrocene couple at $0 \mathrm{~V}$.

Bottom left: evolution of the cathodic peak potential of the $\mathrm{Co}(\mathrm{II} / \mathrm{I})$ wave $\left(\mathrm{E}_{\mathrm{p}, \mathrm{c}}\right)$ with scan rate $(\mathrm{v})$. The slope is $-32 \mathrm{mV} / \mathrm{dec}$, with $\mathrm{R}^{2}=0.998$.

Bottom right: evolution of the obtained $k_{\mathrm{PT}}$ at each scan rate with scan rate. The average yields: $\boldsymbol{k}_{\boldsymbol{P T}}^{\boldsymbol{a p p}}=7.0 \times 10^{5} \mathrm{M}^{-1} \mathrm{~s}^{-1}$ 

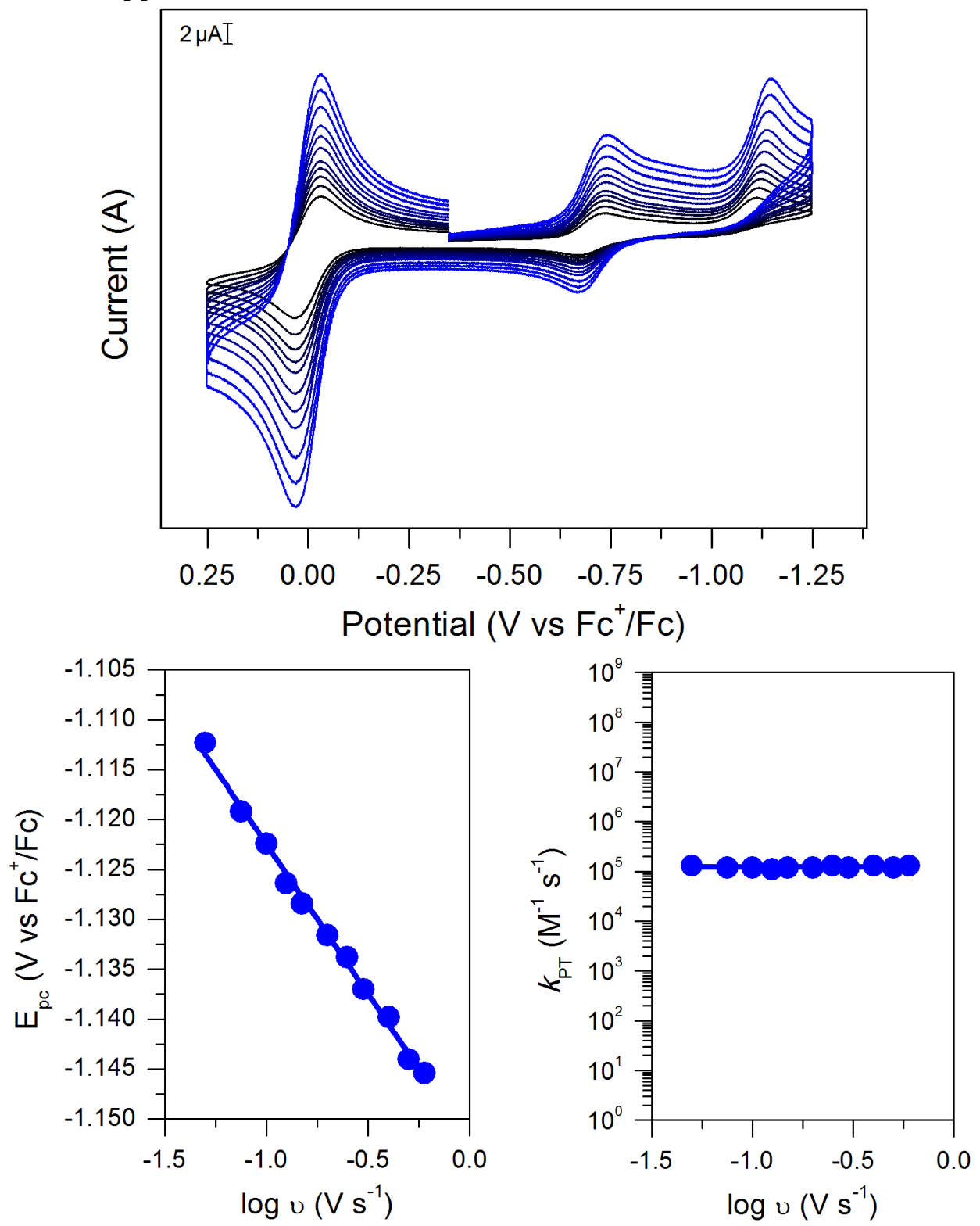

Figure S36. Determination of $\boldsymbol{k}_{\boldsymbol{P} \boldsymbol{T}}^{\boldsymbol{a p p}}$ of CoCp(depe) with 4-Cl-phenol

Top: cyclic voltammograms of $0.2 \mathrm{mM}\left[\mathrm{CoCp}(\right.$ depe $\left.)\left(\mathrm{NCCH}_{3}\right)\right]\left[\mathrm{PF}_{6}\right]_{2}$ in $5 \mathrm{~mL}$ of $\mathrm{CH}_{3} \mathrm{CN}$ with $0.25 \mathrm{M}\left[\mathrm{Bu}_{4} \mathrm{~N}\right]\left[\mathrm{PF}_{6}\right]$ as supporting electrolyte in the presence of $0.108 \mathrm{M}$ of acid at multiple scan rates $(50,75,100,125,150,200,250,300,400,500$ and $600 \mathrm{mV} / \mathrm{s}$ from black to blue). The CVs are referenced to the ferrocenium/ferrocene couple at $0 \mathrm{~V}$.

Bottom left: evolution of the cathodic peak potential of the $\mathrm{Co}(\mathrm{II} / \mathrm{I})$ wave $\left(\mathrm{E}_{\mathrm{p}, \mathrm{c}}\right)$ with scan rate $(\mathrm{U})$. The slope is $-30 \mathrm{mV} / \mathrm{dec}$, with $\mathrm{R}^{2}=0.996$.

Bottom right: evolution of the obtained $k_{\mathrm{PT}}$ at each scan rate with scan rate. The average yields: $\boldsymbol{k}_{\boldsymbol{P T}}^{\boldsymbol{a p p}}=1.2 \times 10^{5} \mathrm{M}^{-1} \mathrm{~s}^{-1}$ 


\section{Determination of $k_{P T}^{a p p}$ of $\mathrm{CoCp}\left(\right.$ depe) with acetic acid (pKa of 23.51 in $\left.\mathrm{CH}_{3} \mathrm{CN}\right)$}
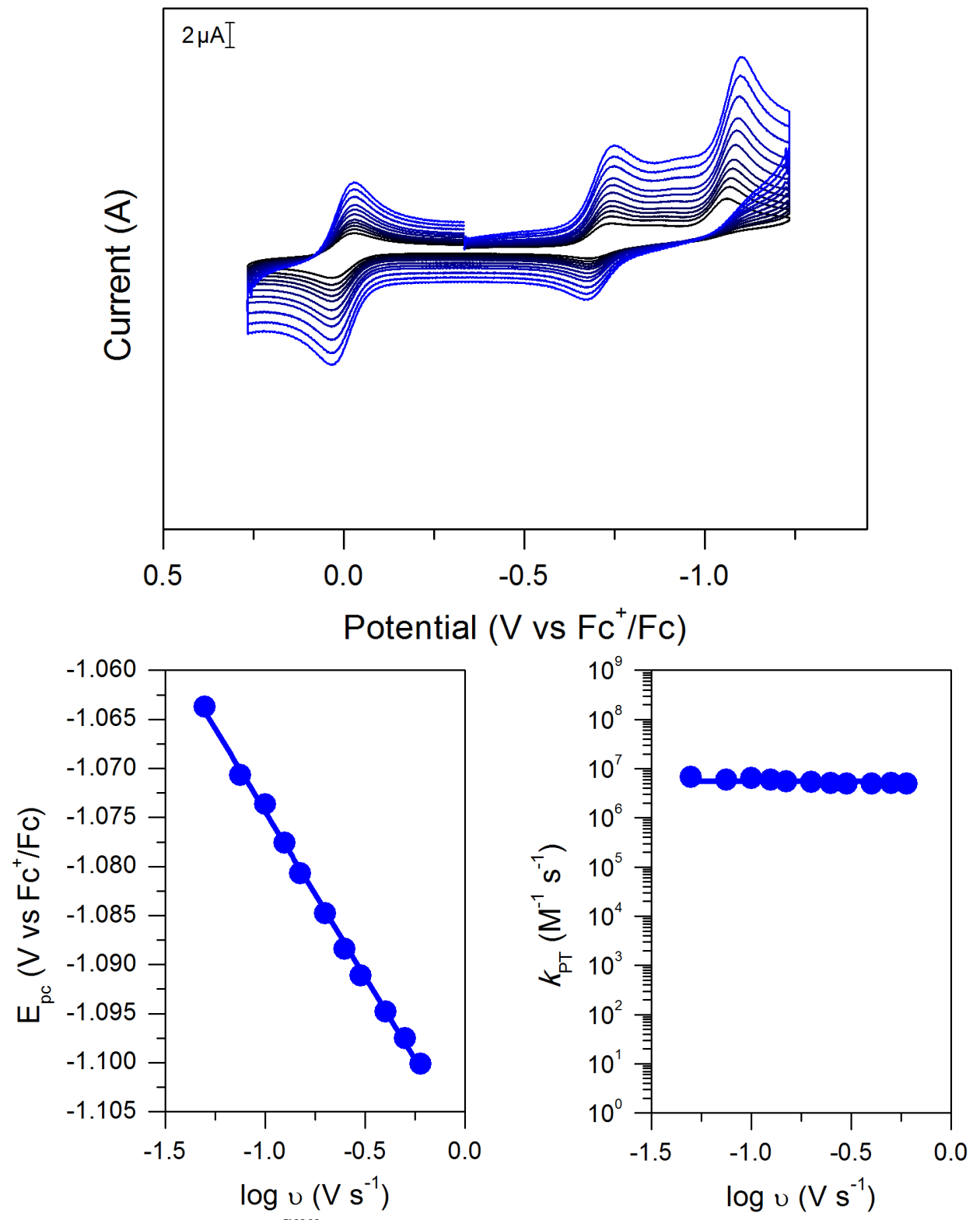

Figure S37. Determination of $\boldsymbol{k}_{\boldsymbol{P T}}^{\boldsymbol{a p p}}$ of $\mathrm{CoCp}$ (depe) with acetic acid

Top: cyclic voltammograms of $0.2 \mathrm{mM}\left[\mathrm{CoCp}(\right.$ depe $\left.)\left(\mathrm{NCCH}_{3}\right)\right]\left[\mathrm{PF}_{6}\right]_{2}$ in $5 \mathrm{~mL}$ of $\mathrm{CH}_{3} \mathrm{CN}$ with $0.25 \mathrm{M}\left[\mathrm{Bu}_{4} \mathrm{~N}\right]\left[\mathrm{PF}_{6}\right]$ as supporting electrolyte in the presence of $0.087 \mathrm{M}$ of acid at multiple scan rates $(50,75,100,125,150,200,250,300,400,500$ and $600 \mathrm{mV} / \mathrm{s}$ from black to blue). The CVs are referenced to the ferrocenium/ferrocene couple at $0 \mathrm{~V}$.

Bottom left: evolution of the cathodic peak potential of the $\mathrm{Co}(\mathrm{II} / \mathrm{I})$ wave $\left(\mathrm{E}_{\mathrm{p}, \mathrm{c}}\right)$ with scan rate $(\mathrm{v})$. The slope is $-34 \mathrm{mV} / \mathrm{dec}$, with $\mathrm{R}^{2}=0.998$.

Bottom right: evolution of the obtained $k_{\mathrm{PT}}$ at each scan rate with scan rate. The average yields: $\boldsymbol{k}_{\boldsymbol{P T}}^{\boldsymbol{a p p}}=5.6 \times 10^{6} \mathrm{M}^{-1} \mathrm{~s}^{-1}$ 

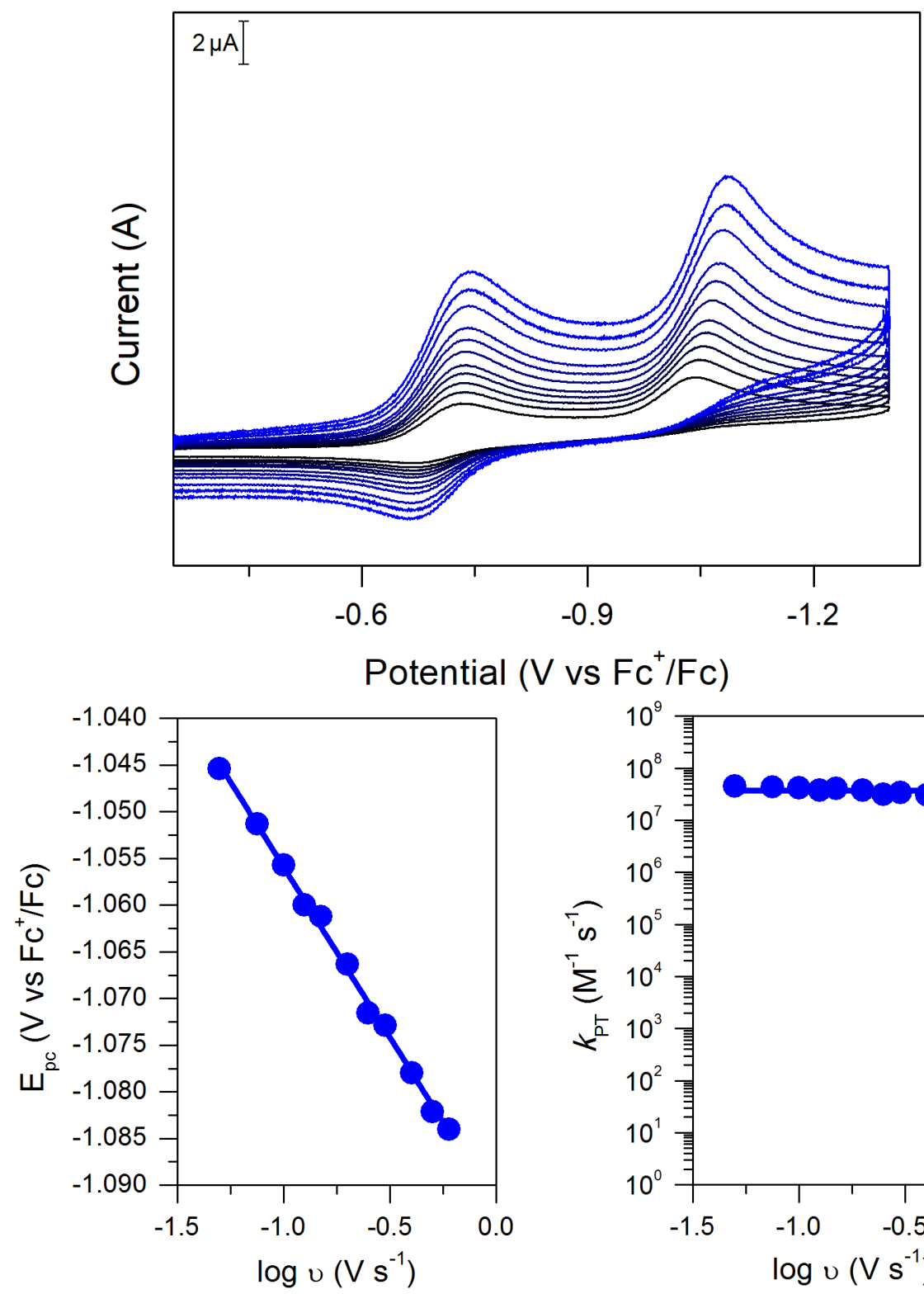

vs $\left.\mathrm{Fc}^{+} / \mathrm{Fc}\right)$

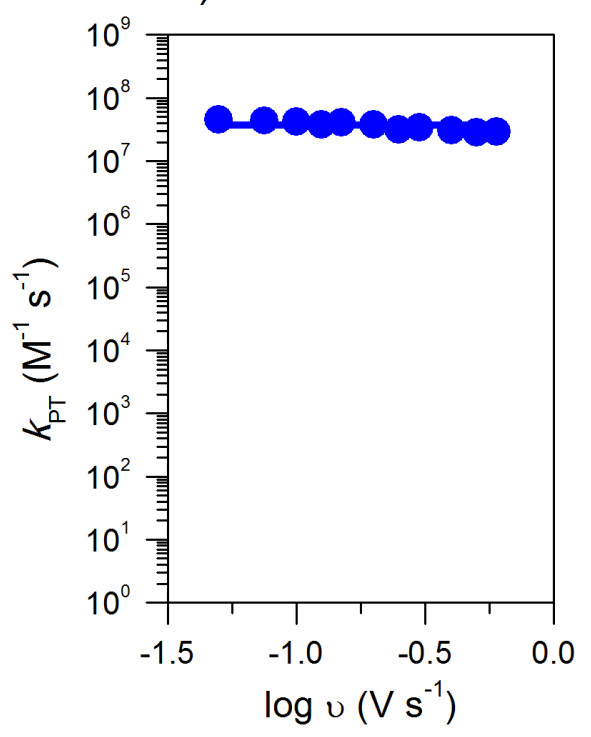

Figure S38. Determination of $\boldsymbol{k}_{\boldsymbol{P T}}^{\boldsymbol{a p p}}$ of $\mathrm{CoCp}(\mathrm{depe})$ with benzoic acid

Top: cyclic voltammograms of $0.2 \mathrm{mM}\left[\mathrm{CoCp}(\right.$ depe $\left.)\left(\mathrm{NCCH}_{3}\right)\right]\left[\mathrm{PF}_{6}\right]_{2}$ in $5 \mathrm{~mL}$ of $\mathrm{CH}_{3} \mathrm{CN}$ with $0.25 \mathrm{M}\left[\mathrm{Bu}_{4} \mathrm{~N}\right]\left[\mathrm{PF}_{6}\right]$ as supporting electrolyte in the presence of $0.050 \mathrm{M}$ of acid at multiple scan rates $(50,75,100,125,150,200,250,300,400,500$ and $600 \mathrm{mV} / \mathrm{s}$ from black to blue). The CVs are referenced to the ferrocenium/ferrocene couple at $0 \mathrm{~V}$.

Bottom left: evolution of the cathodic peak potential of the $\mathrm{Co}(\mathrm{II} / \mathrm{I})$ wave $\left(\mathrm{E}_{\mathrm{p}, \mathrm{c}}\right)$ with scan rate $(\mathrm{v})$. The slope is $-37 \mathrm{mV} / \mathrm{dec}$, with $\mathrm{R}^{2}=0.997$.

Bottom right: evolution of the obtained $k_{\mathrm{PT}}$ at each scan rate with scan rate. The average yields:

$\boldsymbol{k}_{P T}^{\boldsymbol{a p p}}=3.6 \times 10^{7} \mathrm{M}^{-1} \mathrm{~s}^{-1}$ 
Determination of $k_{P T}^{a p p}$ of $\mathrm{CoCp}(\mathrm{depe})$ with 2,3,5,6-tetrafluoro-phenol (pKa of 20.12 in $\mathrm{CH}_{3} \mathrm{CN}$ )
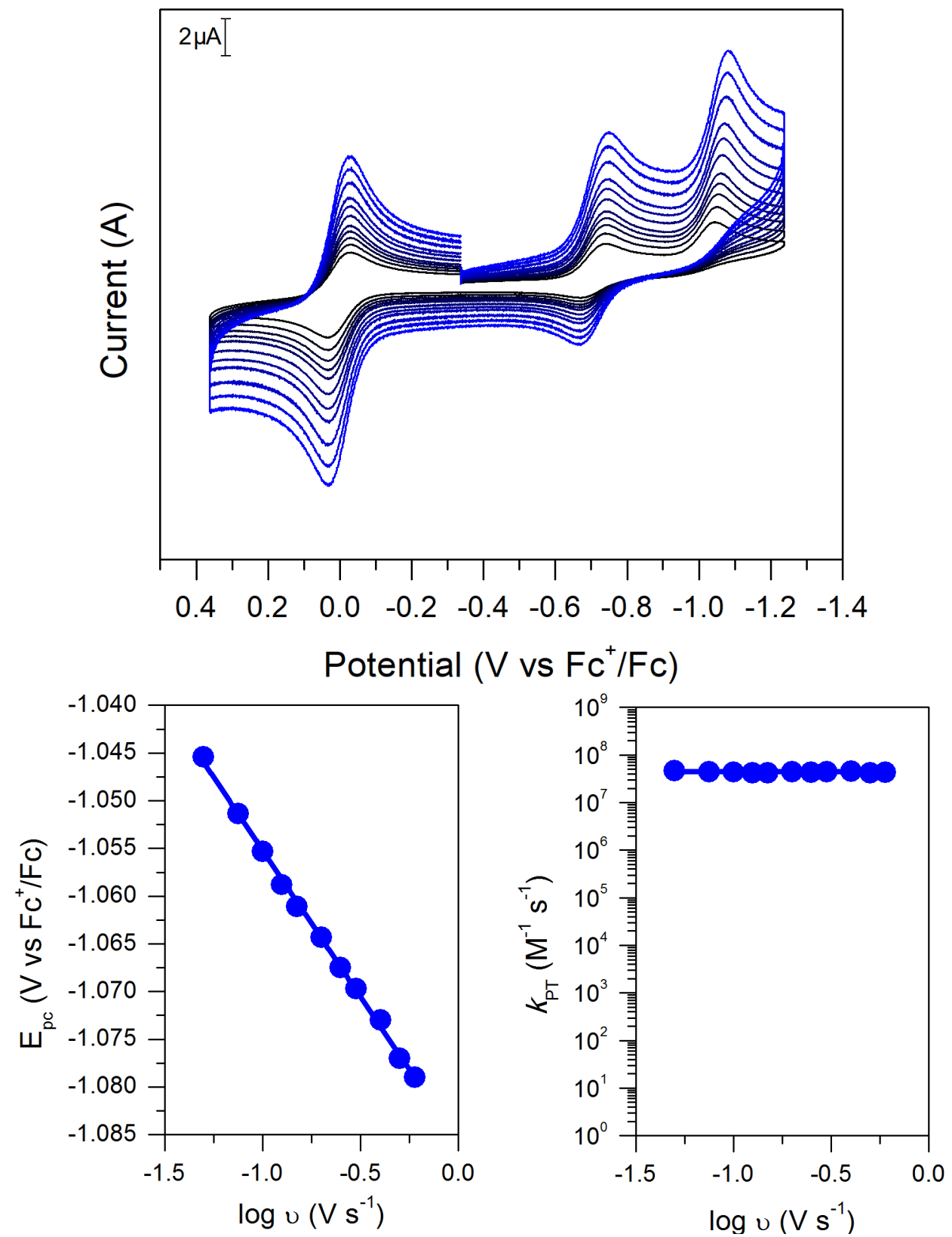

Figure S39. Determination of $k_{P T}^{a p p}$ of CoCp(depe) with 2,3,5,6-tetrafluorophenol Top: cyclic voltammograms of $0.2 \mathrm{mM}\left[\mathrm{CoCp}(\right.$ depe $\left.)\left(\mathrm{NCCH}_{3}\right)\right]\left[\mathrm{PF}_{6}\right]_{2}$ in $5 \mathrm{~mL}$ of $\mathrm{CH}_{3} \mathrm{CN}$ with $0.25 \mathrm{M}\left[\mathrm{Bu}_{4} \mathrm{~N}\right]\left[\mathrm{PF}_{6}\right]$ as supporting electrolyte in the presence of $0.049 \mathrm{M}$ of acid at multiple scan rates $(50,75,100,125,150,200,250,300,400,500$ and $600 \mathrm{mV} / \mathrm{s}$ from black to blue). The CVs are referenced to the ferrocenium/ferrocene couple at $0 \mathrm{~V}$.

Bottom left: evolution of the cathodic peak potential of the $\mathrm{Co}(\mathrm{II} / \mathrm{I})$ wave $\left(\mathrm{E}_{\mathrm{p}, \mathrm{c}}\right)$ with scan rate $(\mathrm{U})$. The slope is $-31 \mathrm{mV} / \mathrm{dec}$, with $\mathrm{R}^{2}=0.999$.

Bottom right: evolution of the obtained $k_{\mathrm{PT}}$ at each scan rate with scan rate. The average yields: $\boldsymbol{k}_{\boldsymbol{P T}}^{\boldsymbol{a p p}}=4.4 \times 10^{7} \mathrm{M}^{-1} \mathrm{~s}^{-1}$ 
Determination of $k_{P T}^{a p p}$ of $\mathrm{CoCp}\left(\right.$ depe) with benzylammonium tetrafluoroborate $\left(\mathrm{p} K_{\mathrm{a}}\right.$ of 16.91 in $\mathrm{CH}_{3} \mathrm{CN}$ )
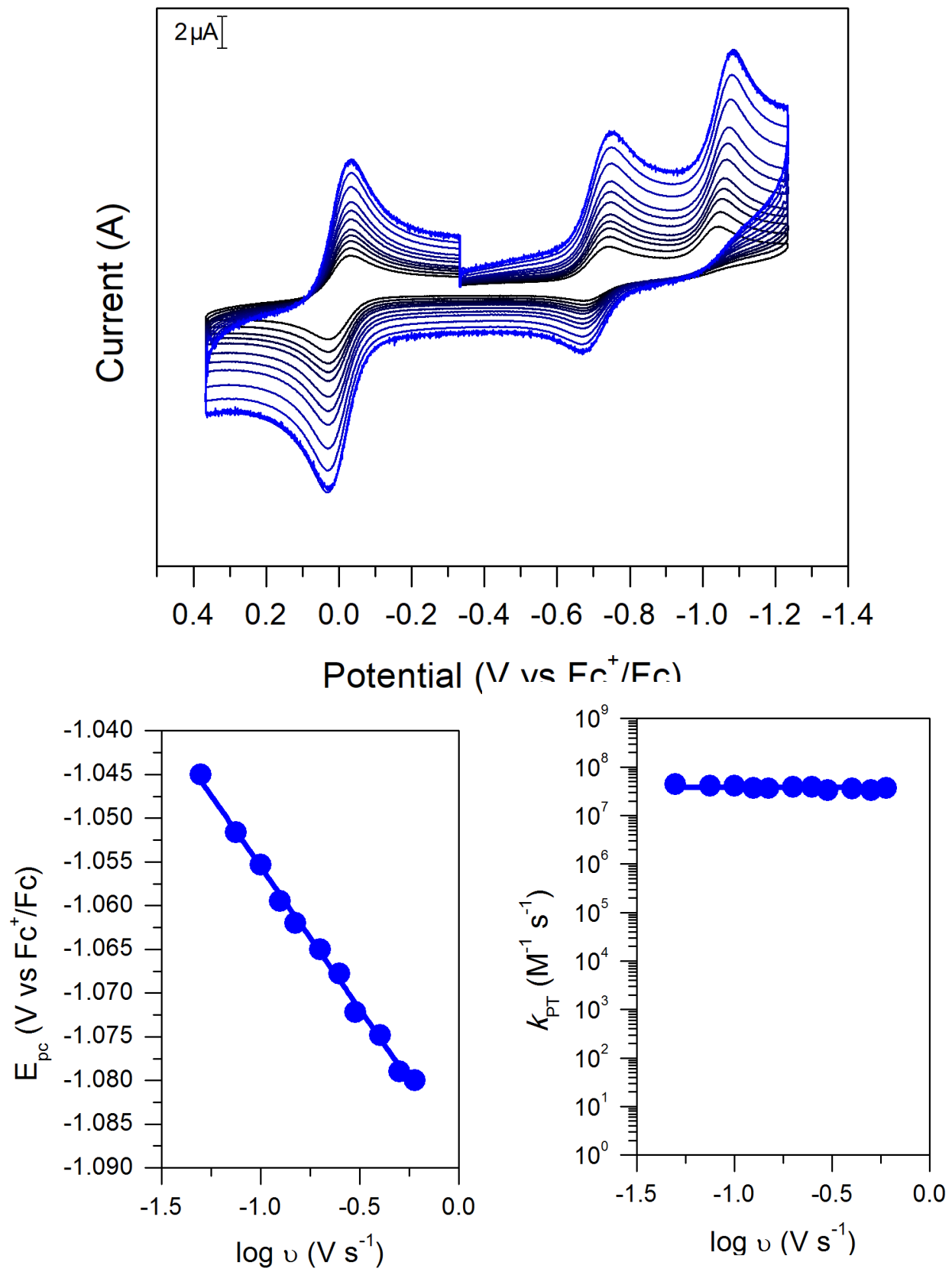

Figure S40. Determination of $\boldsymbol{k}_{\boldsymbol{P T}}^{\boldsymbol{a p p}}$ of $\mathrm{CoCp}$ (depe) with benzylammonium tetrafluoroborate Top: cyclic voltammograms of $0.2 \mathrm{mM}\left[\mathrm{CoCp}(\right.$ depe $\left.)\left(\mathrm{NCCH}_{3}\right)\right]\left[\mathrm{PF}_{6}\right]_{2}$ in $5 \mathrm{~mL}$ of $\mathrm{CH}_{3} \mathrm{CN}$ with $0.25 \mathrm{M}\left[\mathrm{Bu}_{4} \mathrm{~N}\right]\left[\mathrm{PF}_{6}\right]$ as supporting electrolyte in the presence of $0.046 \mathrm{M}$ of acid at multiple scan rates $(50,75,100,125,150,200,250,300,400,500$ and $600 \mathrm{mV} / \mathrm{s}$ from black to blue). The CVs are referenced to the ferrocenium/ferrocene couple at $0 \mathrm{~V}$.

Bottom left: evolution of the cathodic peak potential of the $\mathrm{Co}(\mathrm{II} / \mathrm{I})$ wave $\left(\mathrm{E}_{\mathrm{p}, \mathrm{c}}\right)$ with scan rate $(\mathrm{v})$. The slope is $-33 \mathrm{mV} / \mathrm{dec}$, with $\mathrm{R}^{2}=0.996$.

Bottom right: evolution of the obtained $k_{\mathrm{PT}}$ at each scan rate with scan rate. The average yields: $\boldsymbol{k}_{\boldsymbol{P T}}^{\boldsymbol{a p p}}=3.8 \times 10^{7} \mathrm{M}^{-1} \mathrm{~s}^{-1}$ 
Determination of $k_{P T}^{a p p}$ of $\mathrm{CoCp}(\mathrm{depe})$ with salicylic acid $\left(\mathrm{p} K_{\mathrm{a}}\right.$ of 16.7 in $\left.\mathrm{CH}_{3} \mathrm{CN}\right)$
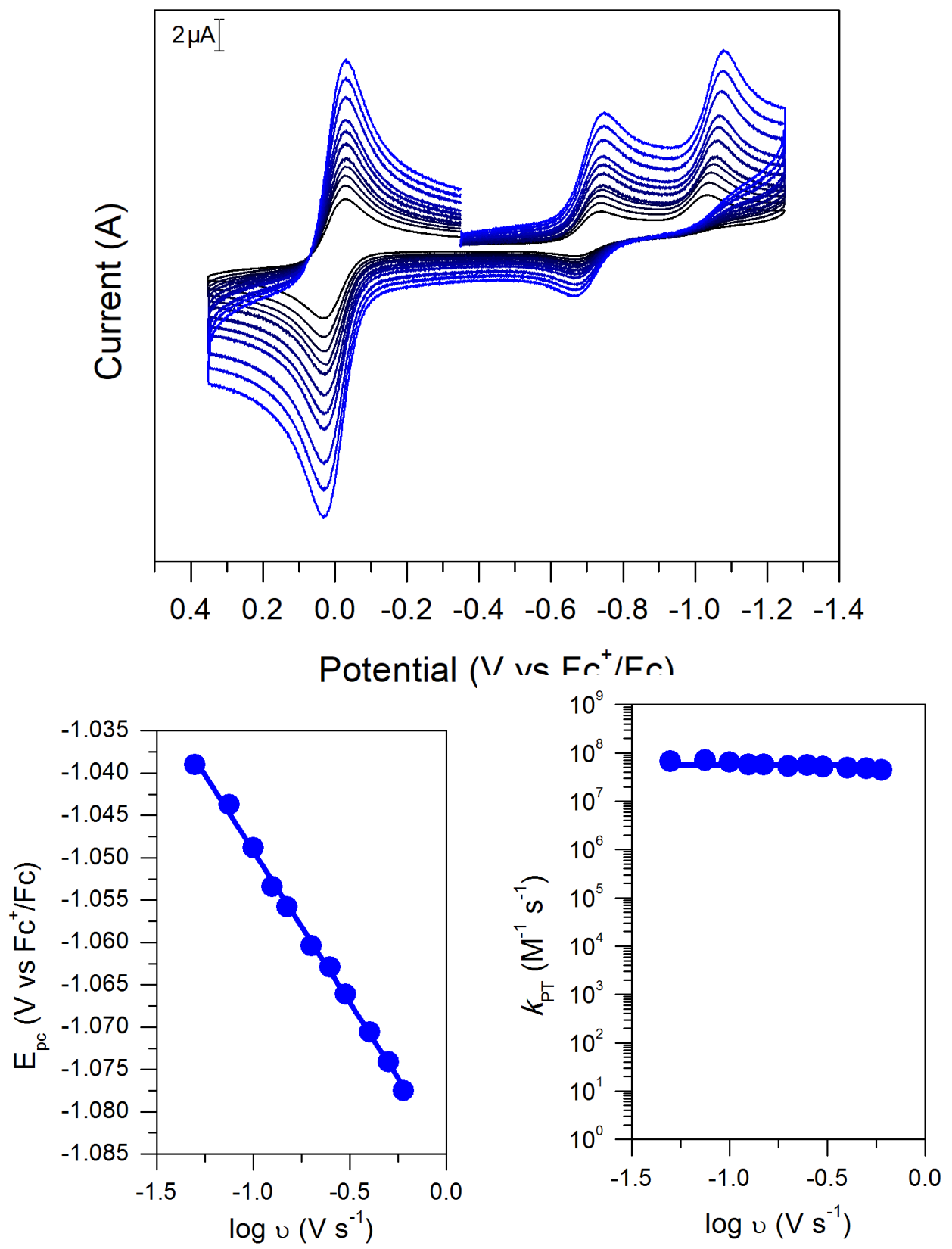

Figure S41. Determination of $\boldsymbol{k}_{\boldsymbol{P T}}^{\boldsymbol{a p p}}$ of $\mathrm{CoCp}(\mathrm{depe})$ with salicylic acid

Top: cyclic voltammograms of $0.2 \mathrm{mM}\left[\mathrm{CoCp}(\right.$ depe $\left.)\left(\mathrm{NCCH}_{3}\right)\right]\left[\mathrm{PF}_{6}\right]_{2}$ in $5 \mathrm{~mL}$ of $\mathrm{CH}_{3} \mathrm{CN}$ with $0.25 \mathrm{M}\left[\mathrm{Bu}_{4} \mathrm{~N}\right]\left[\mathrm{PF}_{6}\right]$ as supporting electrolyte in the presence of $0.055 \mathrm{M}$ of acid at multiple scan rates $(50,75,100,125,150,200,250,300,400,500$ and $600 \mathrm{mV} / \mathrm{s}$ from black to blue). The CVs are referenced to the ferrocenium/ferrocene couple at $0 \mathrm{~V}$.

Bottom left: evolution of the cathodic peak potential of the $\mathrm{Co}(\mathrm{II} / \mathrm{I})$ wave $\left(\mathrm{E}_{\mathrm{p}, \mathrm{c}}\right)$ with scan rate (v). The slope is $-36 \mathrm{mV} / \mathrm{dec}$, with $\mathrm{R}^{2}=0.998$.

Bottom right: evolution of the obtained $k_{\mathrm{PT}}$ at each scan rate with scan rate. The average yields:

$\boldsymbol{k}_{\boldsymbol{P T}}^{\boldsymbol{a p p}}=5.6 \times 10^{7} \mathrm{M}^{-1} \mathrm{~s}^{-1}$ 
Determination of $\boldsymbol{k}_{P T}^{a p p}$ of $\mathrm{CoCp}\left(\right.$ depe) with 4- $\mathrm{CH}_{3} \mathrm{O}$-pyridinium tetrafluoroborate (pK $K_{\mathrm{a}}$ of 14.23 in $\Gamma \mathrm{H}_{2} \mathrm{CN} \mathbf{N}$
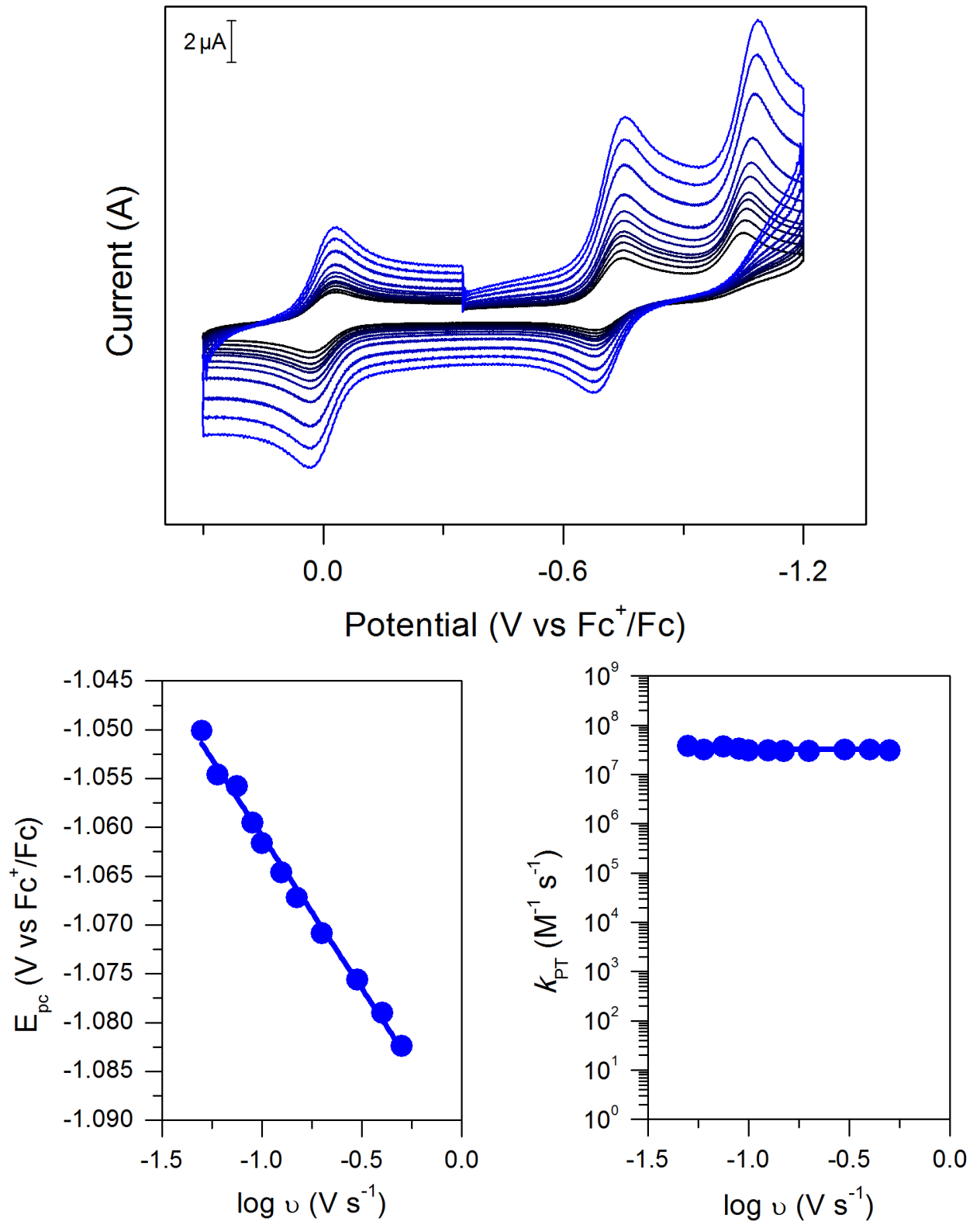

Figure S42. Determination of $\boldsymbol{k}_{\boldsymbol{P T}}^{\boldsymbol{a p p}}$ of $\mathrm{CoCp}\left(\right.$ depe) with $4-\mathrm{CH}_{3} \mathrm{O}$-pyridinium tetrafluoroborate Top: cyclic voltammograms of $0.2 \mathrm{mM}\left[\mathrm{CoCp}(\right.$ depe $\left.)\left(\mathrm{NCCH}_{3}\right)\right]\left[\mathrm{PF}_{6}\right]_{2}$ in $5 \mathrm{~mL}$ of $\mathrm{CH}_{3} \mathrm{CN}$ with $0.25 \mathrm{M}\left[\mathrm{Bu}_{4} \mathrm{~N}\right]\left[\mathrm{PF}_{6}\right]$ as supporting electrolyte in the presence of $0.054 \mathrm{M}$ of acid at multiple scan rates $(50,75,100,125,150,200,250,300,400,500$ and $600 \mathrm{mV} / \mathrm{s}$ from black to blue). The CVs are referenced to the ferrocenium/ferrocene couple at $0 \mathrm{~V}$.

Bottom left: evolution of the cathodic peak potential of the $\mathrm{Co}(\mathrm{II} / \mathrm{I})$ wave $\left(\mathrm{E}_{\mathrm{p}, \mathrm{c}}\right)$ with scan rate $(\mathrm{v})$. The slope is $-31 \mathrm{mV} / \mathrm{dec}$, with $\mathrm{R}^{2}=0.994$.

Bottom right: evolution of the obtained $k_{\mathrm{PT}}$ at each scan rate with scan rate. The average yields: $\boldsymbol{k}_{\boldsymbol{P T}}^{\boldsymbol{a p p}}=3.2 \times 10^{7} \mathrm{M}^{-1} \mathrm{~s}^{-1}$ 
Determination of $\boldsymbol{k}_{P T}^{a p p}$ of $\mathrm{CoCp}(\mathrm{depe})$ with pyridinium tetra-fluoroborate $\left(\mathrm{p} K_{\mathrm{a}}\right.$ of 12.53 in $\mathrm{CH}_{3} \mathrm{CN}$ )
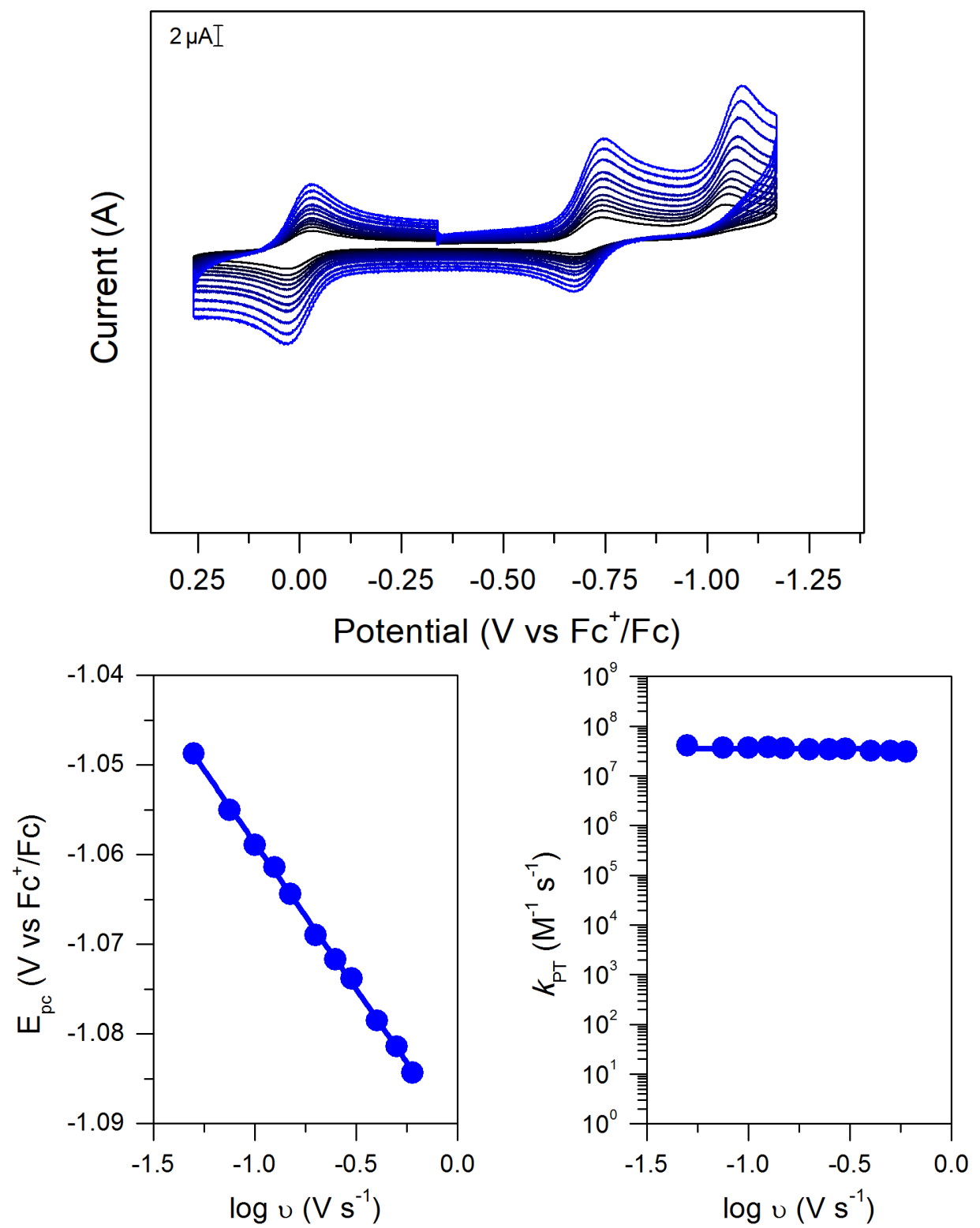

Figure S43. Determination of $\boldsymbol{k}_{\boldsymbol{P T}}^{\boldsymbol{a p p}}$ of CoCp(depe) with pyridinium tetrafluoroborate Top: cyclic voltammograms of $0.2 \mathrm{mM}\left[\mathrm{CoCp}(\right.$ depe $\left.)\left(\mathrm{NCCH}_{3}\right)\right]\left[\mathrm{PF}_{6}\right]_{2}$ in $5 \mathrm{~mL}$ of $\mathrm{CH}_{3} \mathrm{CN}$ with $0.25 \mathrm{M}\left[\mathrm{Bu}_{4} \mathrm{~N}\right]\left[\mathrm{PF}_{6}\right]$ as supporting electrolyte in the presence of $0.049 \mathrm{M}$ of acid at multiple scan rates $(50,75,100,125,150,200,250,300,400,500$ and $600 \mathrm{mV} / \mathrm{s}$ from black to blue). The CVs are referenced to the ferrocenium/ferrocene couple at $0 \mathrm{~V}$.

Bottom left: evolution of the cathodic peak potential of the $\mathrm{Co}(\mathrm{II} / \mathrm{I})$ wave $\left(\mathrm{E}_{\mathrm{p}, \mathrm{c}}\right)$ with scan rate $(\mathrm{U})$. The slope is $-33 \mathrm{mV} / \mathrm{dec}$, with $\mathrm{R}^{2}=0.999$.

Bottom right: evolution of the obtained $k_{\mathrm{PT}}$ at each scan rate with scan rate. The average yields: $\boldsymbol{k}_{\boldsymbol{P T}}^{\boldsymbol{a p p}}=3.5 \times 10^{7} \mathrm{M}^{-1} \mathrm{~s}^{-1}$ 
Determination of $k_{P T}^{a p p}$ of $\mathrm{CoCp}(\mathrm{depe})$ with 4-CH3-anilinium tetrafluoroborate $\left(\mathrm{p} K_{\mathrm{a}}\right.$ of 11.4 in $\mathrm{CH}_{3} \mathrm{CN}$ )
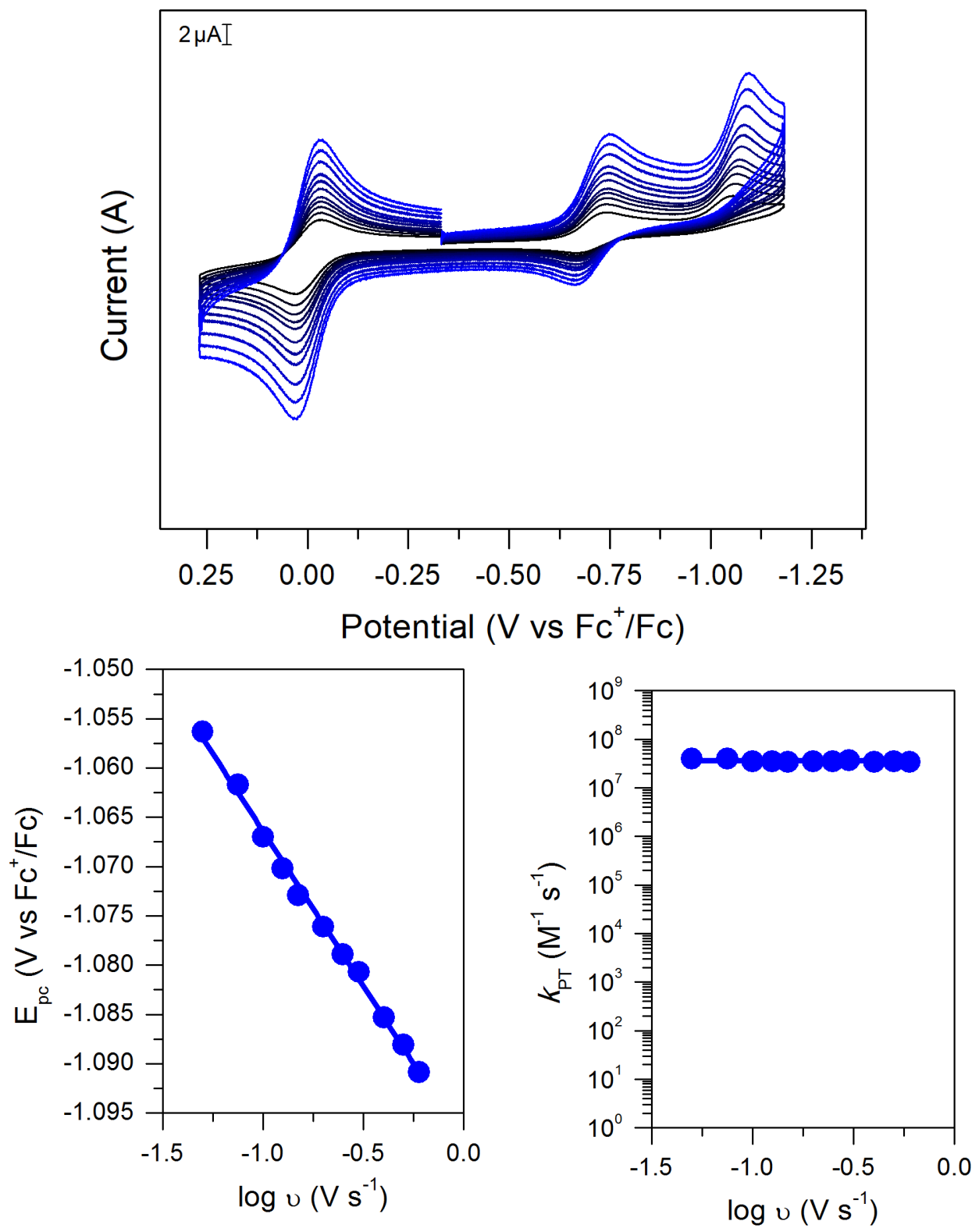

Figure S44. Determination of $\boldsymbol{k}_{\boldsymbol{P T}}^{\boldsymbol{a p p}}$ of CoCp(depe) with 4- $\mathrm{CH}_{3}$-anilinium tetrafluoroborate Top: cyclic voltammograms of $0.2 \mathrm{mM}\left[\mathrm{CoCp}(\right.$ depe $\left.)\left(\mathrm{NCCH}_{3}\right)\right]\left[\mathrm{PF}_{6}\right]_{2}$ in $5 \mathrm{~mL}$ of $\mathrm{CH}_{3} \mathrm{CN}$ with $0.25 \mathrm{M}\left[\mathrm{Bu}_{4} \mathrm{~N}\right]\left[\mathrm{PF}_{6}\right]$ as supporting electrolyte in the presence of $0.030 \mathrm{M}$ of acid at multiple scan rates $(50,75,100,125,150,200,250,300,400,500$ and $600 \mathrm{mV} / \mathrm{s}$ from black to blue). The CVs are referenced to the ferrocenium/ferrocene couple at $0 \mathrm{~V}$.

Bottom left: evolution of the cathodic peak potential of the $\operatorname{Co}(\mathrm{II} / \mathrm{I})$ wave $\left(\mathrm{E}_{\mathrm{p}, \mathrm{c}}\right)$ with scan rate $(\mathrm{v})$. The slope is $-32 \mathrm{mV} / \mathrm{dec}$, with $\mathrm{R}^{2}=0.997$.

Bottom right: evolution of the obtained $k_{\mathrm{PT}}$ at each scan rate with scan rate. The average yields:

$\boldsymbol{k}_{\boldsymbol{P T}}^{\boldsymbol{a p p}}=3.6 \times 10^{7} \mathrm{M}^{-1} \mathrm{~s}^{-1}$ 
Determination of $k_{P T}^{a p p}$ of $\mathrm{CoCp}(\mathrm{depe})$ with ${ }^{4-}{ }^{t} \mathrm{Bu}$-anilinium tetrafluoroborate $\left(\mathrm{p} K_{\mathrm{a}}\right.$ of 11.1 in $\mathrm{CH}_{3} \mathrm{CN}$ )
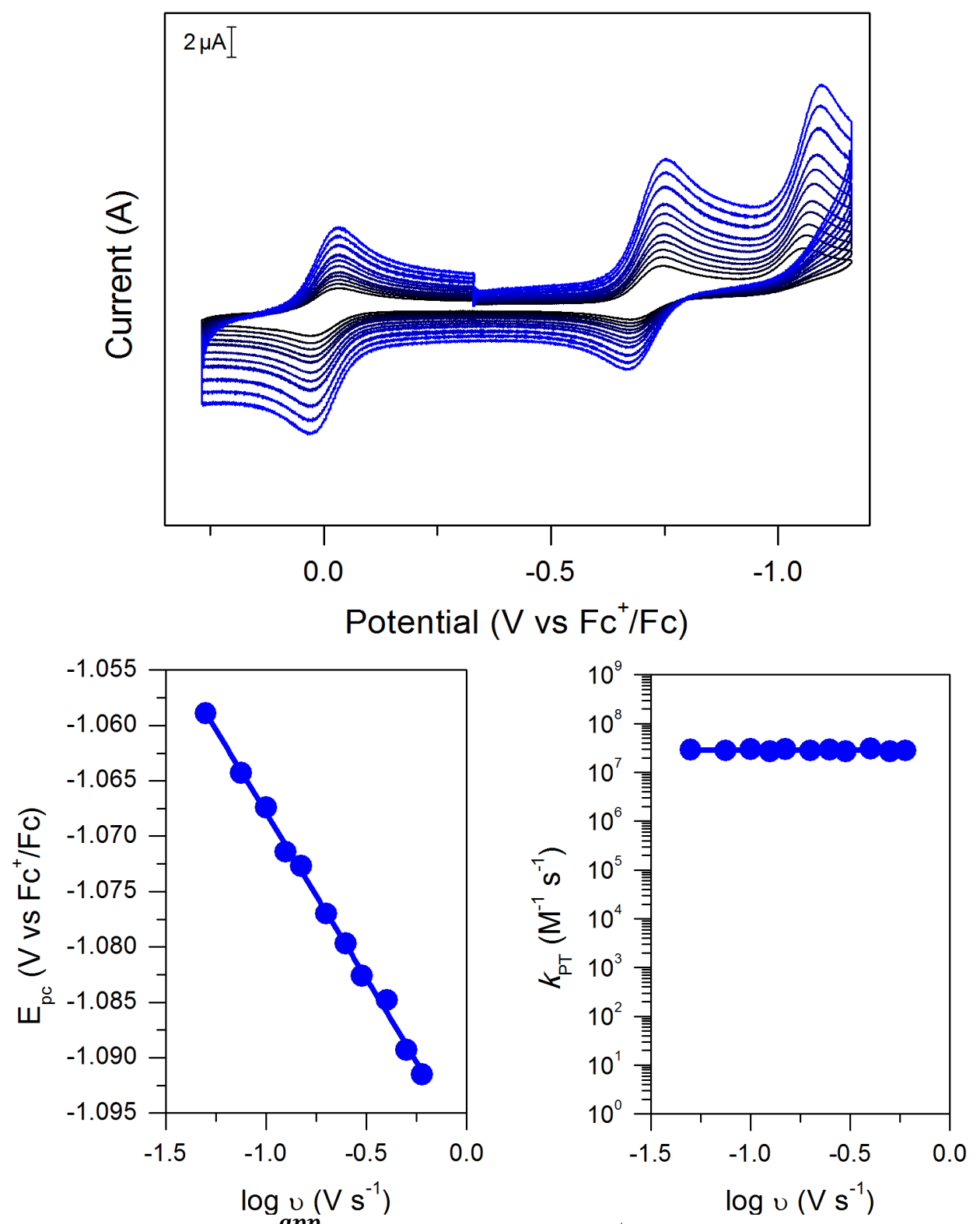

Figure S45. Determination of $\boldsymbol{k}_{\boldsymbol{P T}}^{\boldsymbol{a p p}}$ of $\mathrm{CoCp}(\mathrm{depe})$ with $4-{ }^{t} \mathrm{Bu}$-anilinium tetrafluoroborate Top: cyclic voltammograms of $0.2 \mathrm{mM}\left[\mathrm{CoCp}(\right.$ depe $\left.)\left(\mathrm{NCCH}_{3}\right)\right]\left[\mathrm{PF}_{6}\right]_{2}$ in $5 \mathrm{~mL}$ of $\mathrm{CH}_{3} \mathrm{CN}$ with $0.25 \mathrm{M}\left[\mathrm{Bu}_{4} \mathrm{~N}\right]\left[\mathrm{PF}_{6}\right]$ as supporting electrolyte in the presence of $0.036 \mathrm{M}$ of acid at multiple scan rates $(50,75,100,125,150,200,250,300,400,500$ and $600 \mathrm{mV} / \mathrm{s}$ from black to blue). The CVs are referenced to the ferrocenium/ferrocene couple at $0 \mathrm{~V}$.

Bottom left: evolution of the cathodic peak potential of the $\mathrm{Co}(\mathrm{II} / \mathrm{I})$ wave $\left(\mathrm{E}_{\mathrm{p}, \mathrm{c}}\right)$ with scan rate $(\mathrm{U})$. The slope is $-30 \mathrm{mV} / \mathrm{dec}$, with $\mathrm{R}^{2}=0.998$.

Bottom right: evolution of the obtained $k_{\mathrm{PT}}$ at each scan rate with scan rate. The average yields: $\boldsymbol{k}_{\boldsymbol{P T}}^{\boldsymbol{a p p}}=2.9 \times 10^{7} \mathrm{M}^{-1} \mathrm{~s}^{-1}$ 
Determination of $\boldsymbol{k}_{P T}^{a p p}$ of $\mathrm{CoCp}(\mathrm{depe})$ with 4-Cl-anilinium tetrafluoroborate $\left(\mathrm{p} K_{\mathrm{a}}\right.$ of 9.7 in $\mathrm{CH}_{3} \mathrm{CN}$ )
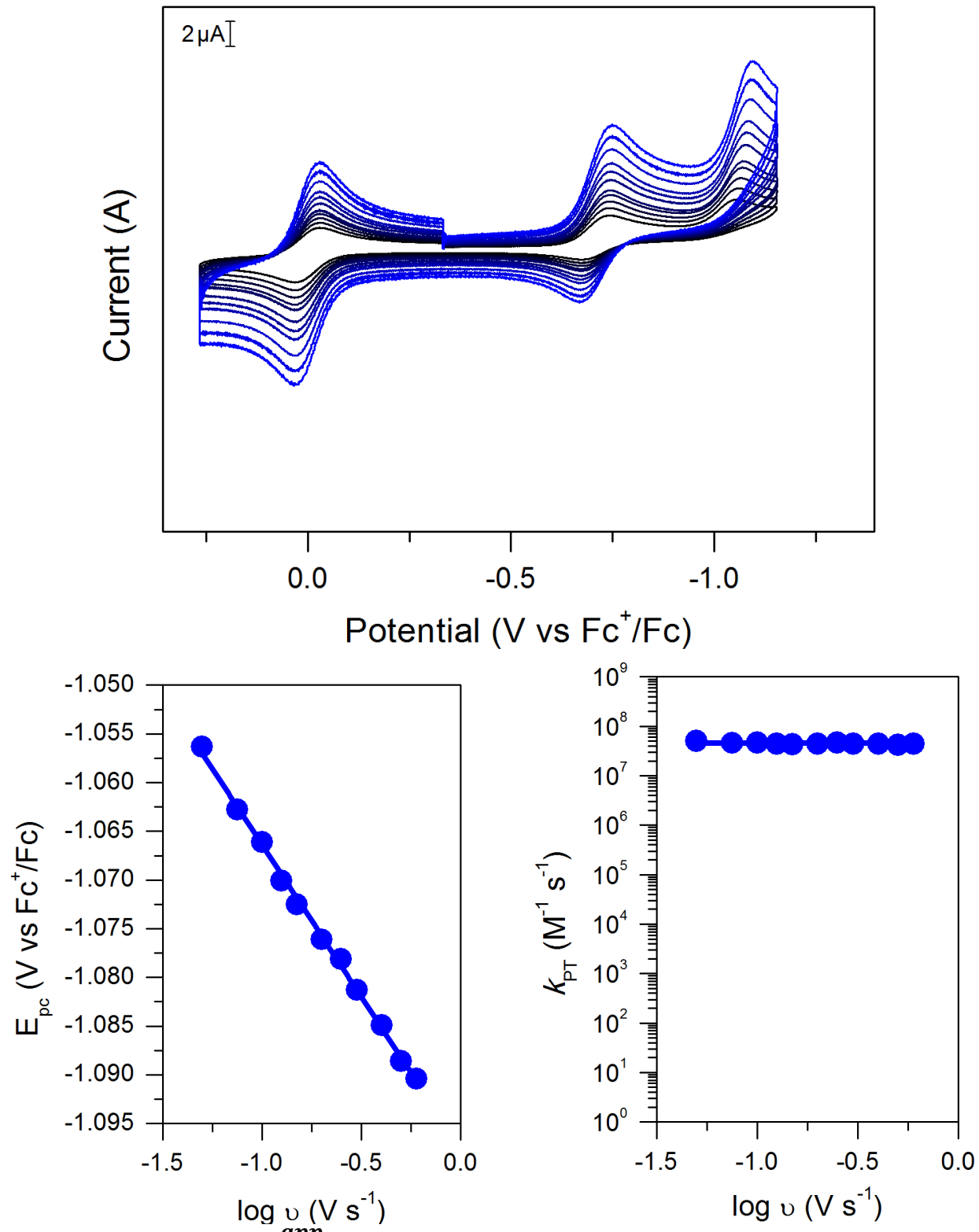

Figure S46. Determination of $\boldsymbol{k}_{\boldsymbol{P T}}^{\boldsymbol{a p p}}$ of CoCp(depe) with 4-Cl-anilinium tetrafluoroborate Top: cyclic voltammograms of $0.2 \mathrm{mM}\left[\mathrm{CoCp}(\right.$ depe $\left.)\left(\mathrm{NCCH}_{3}\right)\right]\left[\mathrm{PF}_{6}\right]_{2}$ in $5 \mathrm{~mL}$ of $\mathrm{CH}_{3} \mathrm{CN}$ with $0.25 \mathrm{M}\left[\mathrm{Bu}_{4} \mathrm{~N}\right]\left[\mathrm{PF}_{6}\right]$ as supporting electrolyte in the presence of $0.022 \mathrm{M}$ of acid at multiple scan rates $(50,75,100,125,150,200,250,300,400,500$ and $600 \mathrm{mV} / \mathrm{s}$ from black to blue). The CVs are referenced to the ferrocenium/ferrocene couple at $0 \mathrm{~V}$.

Bottom left: evolution of the cathodic peak potential of the $\mathrm{Co}(\mathrm{II} / \mathrm{I})$ wave $\left(\mathrm{E}_{\mathrm{p}, \mathrm{c}}\right)$ with scan rate $(\mathrm{U})$. The slope is $-31 \mathrm{mV} / \mathrm{dec}$, with $\mathrm{R}^{2}=0.998$.

Bottom right: evolution of the obtained $k_{\mathrm{PT}}$ at each scan rate with scan rate. The average yields:

$\boldsymbol{k}_{\boldsymbol{P T}}^{\boldsymbol{a p p}}=4.5 \times 10^{7} \mathrm{M}^{-1} \mathrm{~s}^{-1}$ 
Determination of $k_{P T}^{a p p}$ of $\mathrm{CoCp}\left(\right.$ depe) with 4-CF $\mathrm{CF}_{3} \mathrm{O}$-anilinium tetrafluoroborate $\left(\mathrm{p} K_{\mathrm{a}}\right.$ of 9.28 in $\mathrm{CH}_{3} \mathrm{CN}$ )
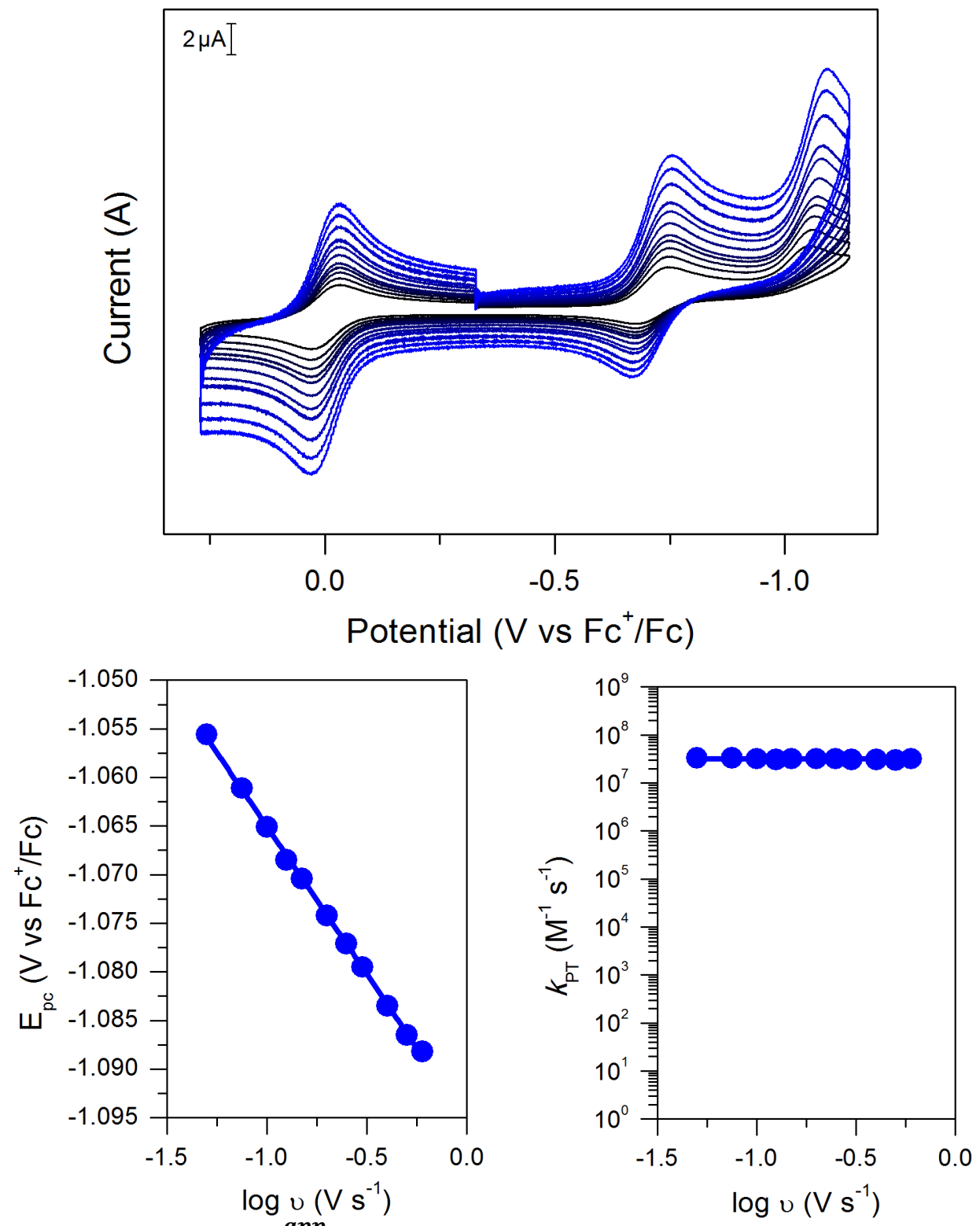

Figure S47. Determination of $\boldsymbol{k}_{\boldsymbol{P} \boldsymbol{T}}^{\boldsymbol{a p p}}$ of $\mathrm{CoCp}(\mathrm{depe})$ with $4-\mathrm{CF}_{3} \mathrm{O}$-anilinium tetrafluoroborate Top: cyclic voltammograms of $0.2 \mathrm{mM}\left[\mathrm{CoCp}(\right.$ depe $\left.)\left(\mathrm{NCCH}_{3}\right)\right]\left[\mathrm{PF}_{6}\right]_{2}$ in $5 \mathrm{~mL}$ of $\mathrm{CH}_{3} \mathrm{CN}$ with $0.25 \mathrm{M}\left[\mathrm{Bu}_{4} \mathrm{~N}\right]\left[\mathrm{PF}_{6}\right]$ as supporting electrolyte in the presence of $0.036 \mathrm{M}$ of acid at multiple scan rates $(50,75,100,125,150,200,250,300,400,500$ and $600 \mathrm{mV} / \mathrm{s}$ from black to blue). The CVs are referenced to the ferrocenium/ferrocene couple at $0 \mathrm{~V}$.

Bottom left: evolution of the cathodic peak potential of the $\mathrm{Co}(\mathrm{II} / \mathrm{I})$ wave $\left(\mathrm{E}_{\mathrm{p}, \mathrm{c}}\right)$ with scan rate $(\mathrm{v})$. The slope is $-30 \mathrm{mV} / \mathrm{dec}$, with $\mathrm{R}^{2}=0.999$.

Bottom right: evolution of the obtained $k_{\mathrm{PT}}$ at each scan rate with scan rate. The average yields: $\boldsymbol{k}_{\boldsymbol{P T}}^{\boldsymbol{a p p}}=3.2 \times 10^{7} \mathrm{M}^{-1} \mathrm{~s}^{-1}$ 
Determination of $\boldsymbol{k}_{P T}^{a p p}$ of $\mathrm{CoCp}(\mathrm{depe})$ with 4-CN-anilinium tetrafluoroborate $\left(\mathrm{p} K_{\mathrm{a}}\right.$ of 7 in $\mathrm{CH}_{3} \mathrm{CN}$ )
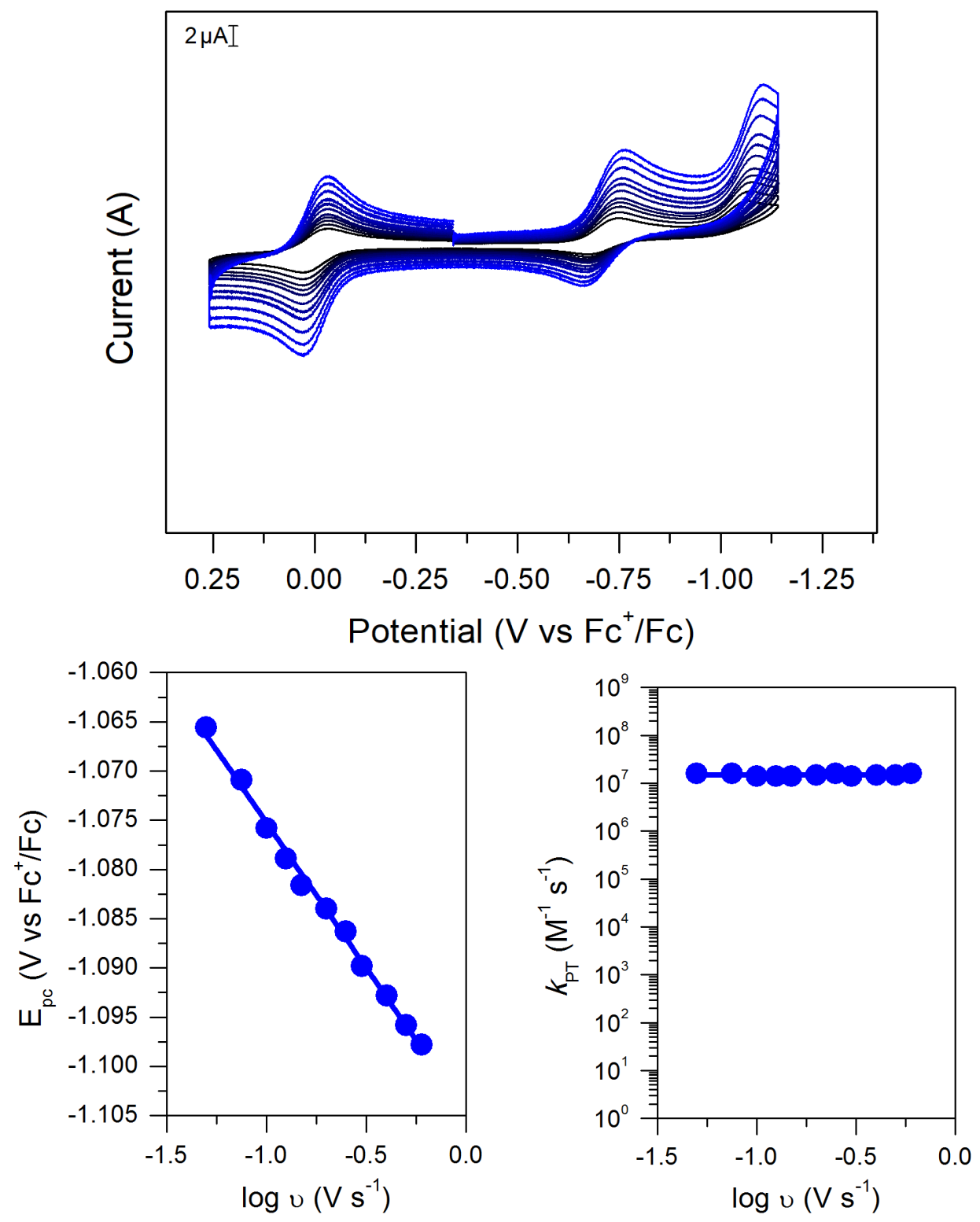

Figure S48. Determination of $\boldsymbol{k}_{\boldsymbol{P T}}^{\boldsymbol{a p p}}$ of CoCp(depe) with 4-CN-anilinium tetrafluoroborate Top: cyclic voltammograms of $0.2 \mathrm{mM}\left[\mathrm{CoCp}(\right.$ depe $\left.)\left(\mathrm{NCCH}_{3}\right)\right]\left[\mathrm{PF}_{6}\right]_{2}$ in $5 \mathrm{~mL}$ of $\mathrm{CH}_{3} \mathrm{CN}$ with $0.25 \mathrm{M}\left[\mathrm{Bu}_{4} \mathrm{~N}\right]\left[\mathrm{PF}_{6}\right]$ as supporting electrolyte in the presence of $0.038 \mathrm{M}$ of acid at multiple scan rates $(50,75,100,125,150,200,250,300,400,500$ and $600 \mathrm{mV} / \mathrm{s}$ from black to blue). The CVs are referenced to the ferrocenium/ferrocene couple at $0 \mathrm{~V}$.

Bottom left: evolution of the cathodic peak potential of the $\mathrm{Co}(\mathrm{II} / \mathrm{I})$ wave $\left(\mathrm{E}_{\mathrm{p}, \mathrm{c}}\right)$ with scan rate $(\mathrm{U})$. The slope is $-30 \mathrm{mV} / \mathrm{dec}$, with $\mathrm{R}^{2}=0.996$.

Bottom right: evolution of the obtained $k_{\mathrm{PT}}$ at each scan rate with scan rate. The average yields: $\boldsymbol{k}_{\boldsymbol{P T}}^{\boldsymbol{a p p}}=1.5 \times 10^{7} \mathrm{M}^{-1} \mathrm{~s}^{-1}$ 

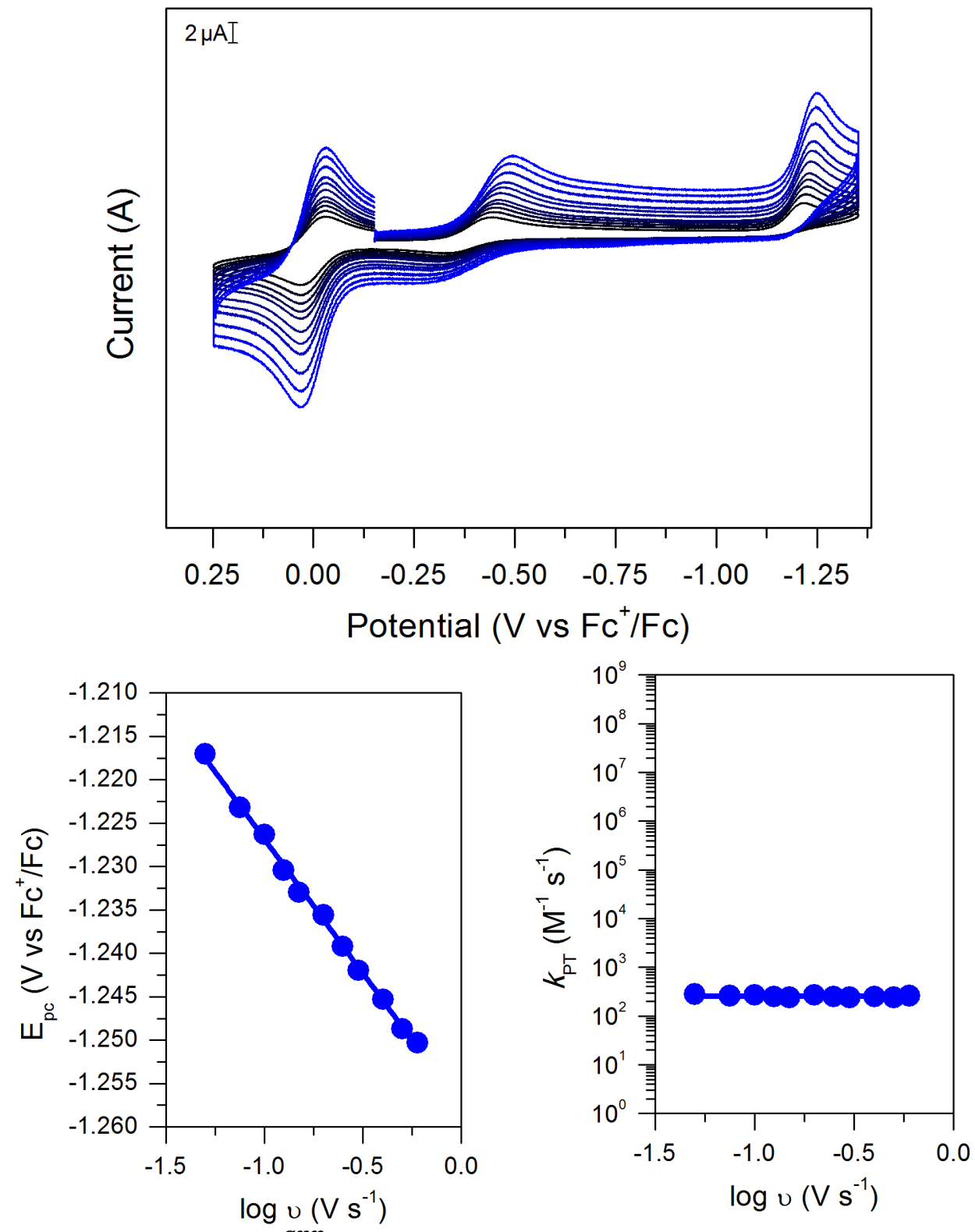

Figure S49. Determination of $\boldsymbol{k}_{P T}^{\boldsymbol{a p p}}$ of CoCp(dcpe) with 4-Cl-phenol

Top: cyclic voltammograms of $0.2 \mathrm{mM}\left[\mathrm{CoCp}(\mathrm{dcpe})\left(\mathrm{NCCH}_{3}\right)\right]\left[\mathrm{PF}_{6}\right]_{2}$ in $5 \mathrm{~mL}$ of $\mathrm{CH}_{3} \mathrm{CN}$ with $0.25 \mathrm{M}\left[\mathrm{Bu}_{4} \mathrm{~N}\right]\left[\mathrm{PF}_{6}\right]$ as supporting electrolyte in the presence of $0.790 \mathrm{M}$ of acid at multiple scan rates $(50,75,100,125,150,200,250,300,400,500$ and $600 \mathrm{mV} / \mathrm{s}$ from black to blue). The CVs are referenced to the ferrocenium/ferrocene couple at $0 \mathrm{~V}$.

Bottom left: evolution of the cathodic peak potential of the $\mathrm{Co}(\mathrm{II} / \mathrm{I})$ wave $\left(\mathrm{E}_{\mathrm{p}, \mathrm{c}}\right)$ with scan rate $(\mathrm{v})$. The slope is $-31 \mathrm{mV} / \mathrm{dec}$, with $\mathrm{R}^{2}=0.998$.

Bottom right: evolution of the obtained $k_{\mathrm{PT}}$ at each scan rate with scan rate. The average yields: $\boldsymbol{k}_{\boldsymbol{P T}}^{\boldsymbol{a p p}}=2.6 \times 10^{2} \mathrm{M}^{-1} \mathrm{~s}^{-1}$ 
Determination of $k_{P T}^{a p p}$ of $\mathrm{CoCp}(\mathrm{dcpe})$ with acetic acid (pKa of 23.51 in $\left.\mathrm{CH}_{3} \mathrm{CN}\right)$
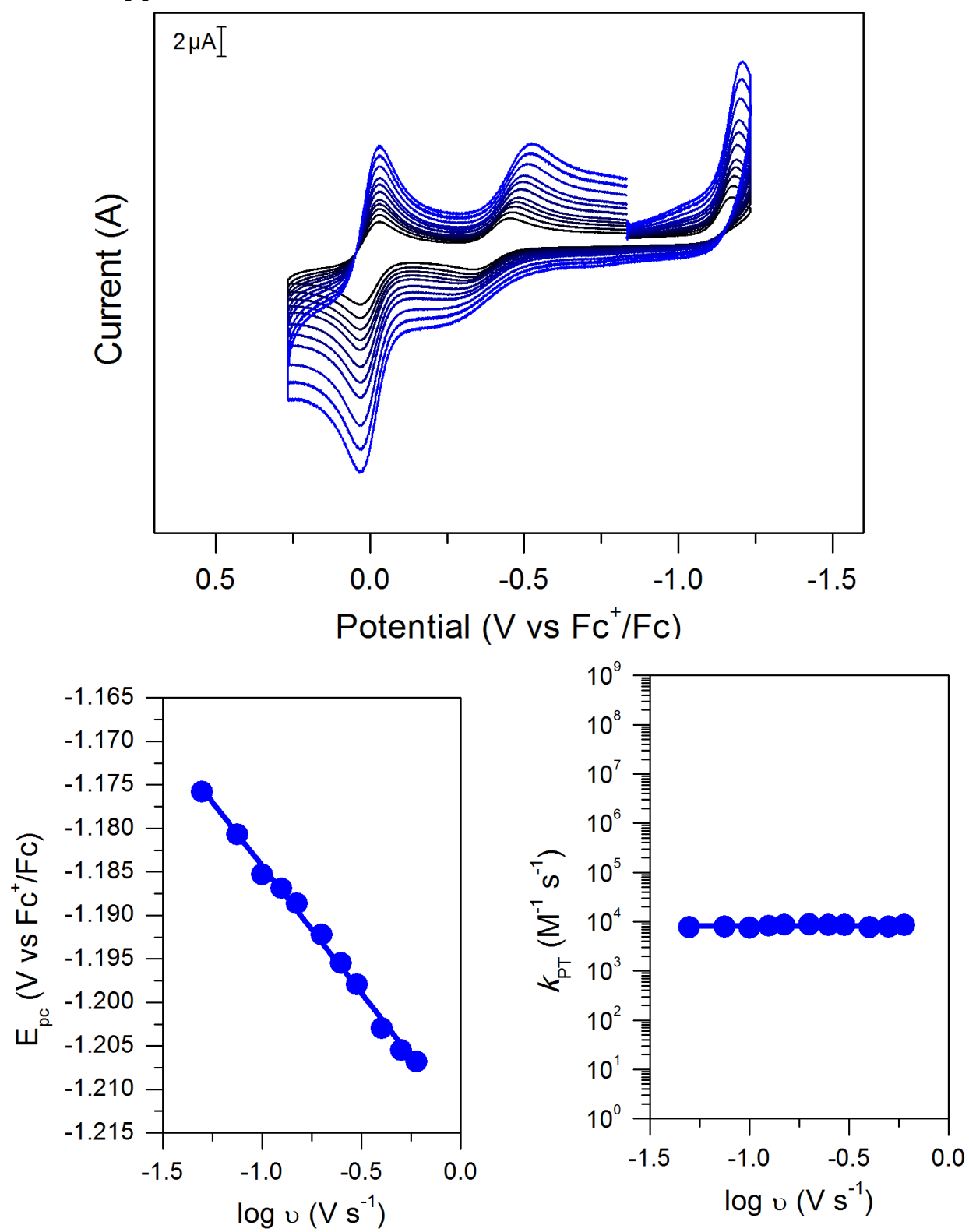

Figure S50. Determination of $\boldsymbol{k}_{\boldsymbol{P T}}^{\boldsymbol{a p p}}$ of CoCp(dcpe) with acetic acid

Top: cyclic voltammograms of $0.2 \mathrm{mM}\left[\mathrm{CoCp}(\mathrm{dcpe})\left(\mathrm{NCCH}_{3}\right)\right]\left[\mathrm{PF}_{6}\right]_{2}$ in $5 \mathrm{~mL}$ of $\mathrm{CH}_{3} \mathrm{CN}$ with $0.25 \mathrm{M}\left[\mathrm{Bu}_{4} \mathrm{~N}\right]\left[\mathrm{PF}_{6}\right]$ as supporting electrolyte in the presence of $0.310 \mathrm{M}$ of acid at multiple scan rates $(50,75,100,125,150,200,250,300,400,500$ and $600 \mathrm{mV} / \mathrm{s}$ from black to blue). The CVs are referenced to the ferrocenium/ferrocene couple at $0 \mathrm{~V}$.

Bottom left: evolution of the cathodic peak potential of the $\mathrm{Co}(\mathrm{II} / \mathrm{I})$ wave $\left(\mathrm{E}_{\mathrm{p}, \mathrm{c}}\right)$ with scan rate $(\mathrm{U})$. The slope is $-29 \mathrm{mV} / \mathrm{dec}$, with $\mathrm{R}^{2}=0.995$.

Bottom right: evolution of the obtained $k_{\mathrm{PT}}$ at each scan rate with scan rate. The average yields: $\boldsymbol{k}_{\boldsymbol{P T}}^{\boldsymbol{a p p}}=8.2 \times 10^{3} \mathrm{M}^{-1} \mathrm{~s}^{-1}$ 
Determination of $k_{P T}^{a p p}$ of $\mathrm{CoCp}(\mathrm{dcpe})$ with 2,3,5,6-tetrafluoro-phenol (pKa of 20.12 in $\mathrm{CH}_{3} \mathrm{CN}$ )
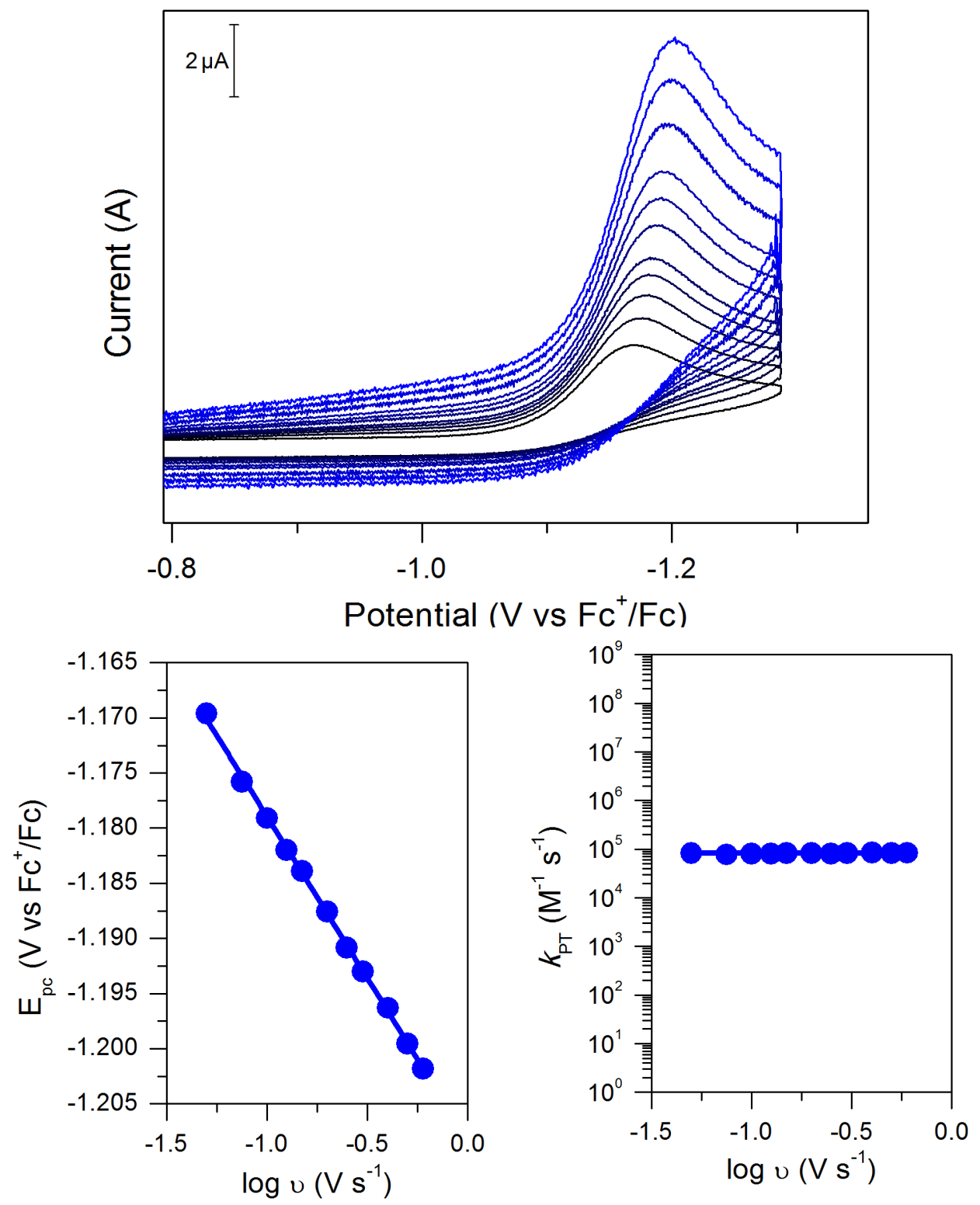

Figure S51. Determination of $\boldsymbol{k}_{\boldsymbol{P T}}^{\boldsymbol{a p p}}$ of CoCp(dcpe) with 2,3,5,6-tetrafluorophenol Top: cyclic voltammograms of $0.2 \mathrm{mM}\left[\mathrm{CoCp}(\mathrm{dcpe})\left(\mathrm{NCCH}_{3}\right)\right]\left[\mathrm{PF}_{6}\right]_{2}$ in $5 \mathrm{~mL}$ of $\mathrm{CH}_{3} \mathrm{CN}$ with $0.25 \mathrm{M}\left[\mathrm{Bu}_{4} \mathrm{~N}\right]\left[\mathrm{PF}_{6}\right]$ as supporting electrolyte in the presence of $0.063 \mathrm{M}$ of acid at multiple scan rates $(50,75,100,125,150,200,250,300,400,500$ and $600 \mathrm{mV} / \mathrm{s}$ from black to blue). The CVs are referenced to the ferrocenium/ferrocene couple at $0 \mathrm{~V}$.

Bottom left: evolution of the cathodic peak potential of the $\mathrm{Co}(\mathrm{II} / \mathrm{I})$ wave $\left(\mathrm{E}_{\mathrm{p}, \mathrm{c}}\right)$ with scan rate $(\mathrm{U})$. The slope is $-29 \mathrm{mV} / \mathrm{dec}$, with $\mathrm{R}^{2}=0.999$.

Bottom right: evolution of the obtained $k_{\mathrm{PT}}$ at each scan rate with scan rate. The average yields: $\boldsymbol{k}_{\boldsymbol{P T}}^{\boldsymbol{a p p}}=8.2 \times 10^{4} \mathrm{M}^{-1} \mathrm{~s}^{-1}$ 
Determination of $k_{P T}^{a p p}$ of $\mathrm{CoCp}(\mathrm{dcpe})$ with 2,3,4,5,6-penta-fluorophenol (pKa $K_{\mathrm{a}}$ of 20.11 in $\mathrm{CH}_{3} \mathrm{CN}$ )
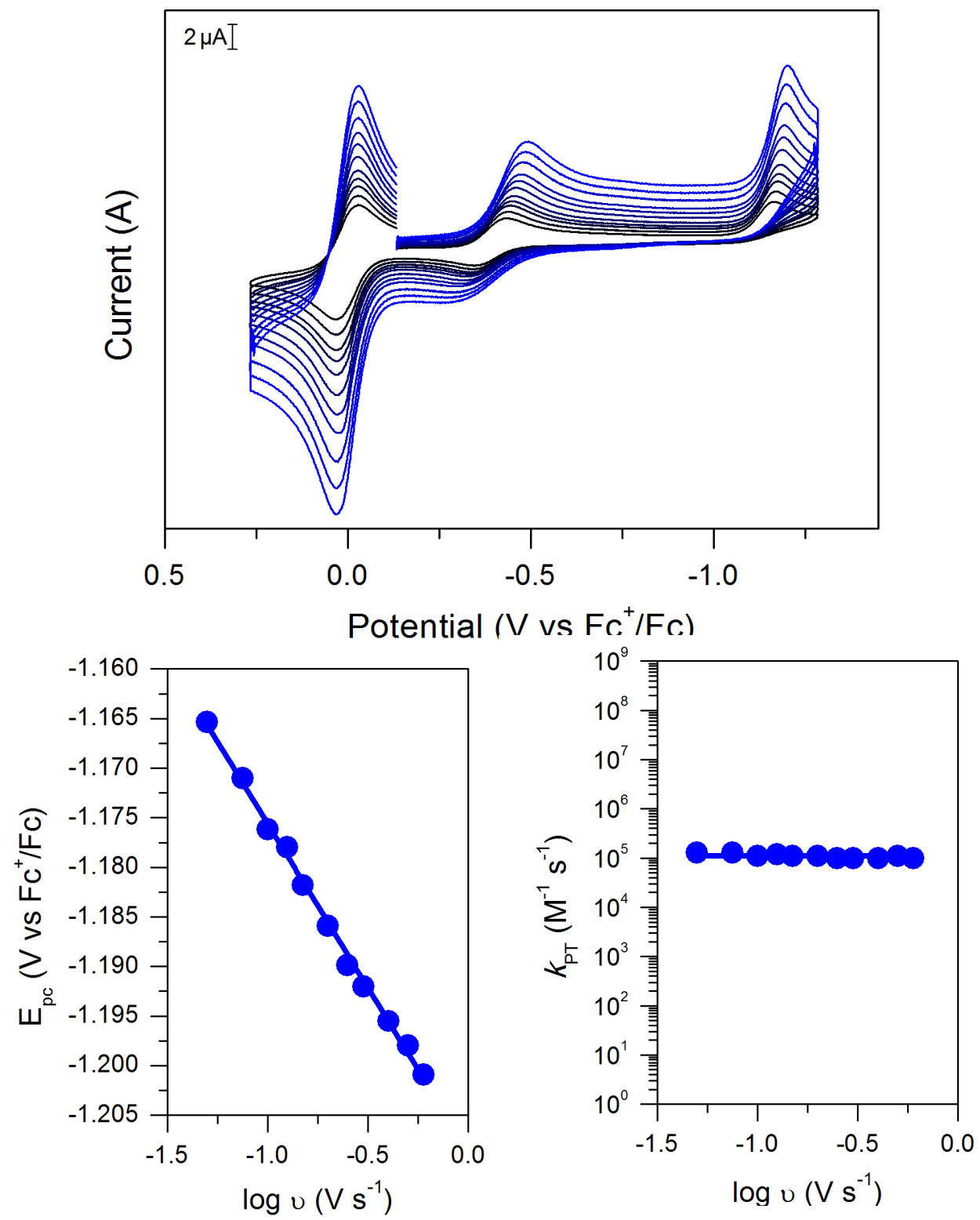

Figure S52. Determination of $\boldsymbol{k}_{\boldsymbol{P T}}^{\boldsymbol{a p p}}$ of CoCp(dcpe) with 2,3,4,5,6-pentafluorophenol Top: cyclic voltammograms of $0.2 \mathrm{mM}\left[\mathrm{CoCp}(\mathrm{dcpe})\left(\mathrm{NCCH}_{3}\right)\right]\left[\mathrm{PF}_{6}\right]_{2}$ in $5 \mathrm{~mL}$ of $\mathrm{CH}_{3} \mathrm{CN}$ with $0.25 \mathrm{M}\left[\mathrm{Bu}_{4} \mathrm{~N}\right]\left[\mathrm{PF}_{6}\right]$ as supporting electrolyte in the presence of $0.057 \mathrm{M}$ of acid at multiple scan rates $(50,75,100,125,150,200,250,300,400,500$ and $600 \mathrm{mV} / \mathrm{s}$ from black to blue). The CVs are referenced to the ferrocenium/ferrocene couple at $0 \mathrm{~V}$.

Bottom left: evolution of the cathodic peak potential of the $\mathrm{Co}(\mathrm{II} / \mathrm{I})$ wave $\left(\mathrm{E}_{\mathrm{p}, \mathrm{c}}\right)$ with scan rate $(\mathrm{v})$. The slope is $-33 \mathrm{mV} / \mathrm{dec}$, with $\mathrm{R}^{2}=0.997$.

Bottom right: evolution of the obtained $k_{\mathrm{PT}}$ at each scan rate with scan rate. The average yields: $\boldsymbol{k}_{\boldsymbol{P T}}^{\boldsymbol{a p p}}=1.1 \times 10^{5} \mathrm{M}^{-1} \mathrm{~s}^{-1}$ 
Determination of $k_{P T}^{a p p}$ of $\mathrm{CoCp}(\mathrm{dcpe})$ with 2,3,5,6-tetrafluoro-4-CF - -phenol (pK $K_{\mathrm{a}}$ of 16.62 in $\mathrm{CH}_{3} \mathrm{CN}$ )
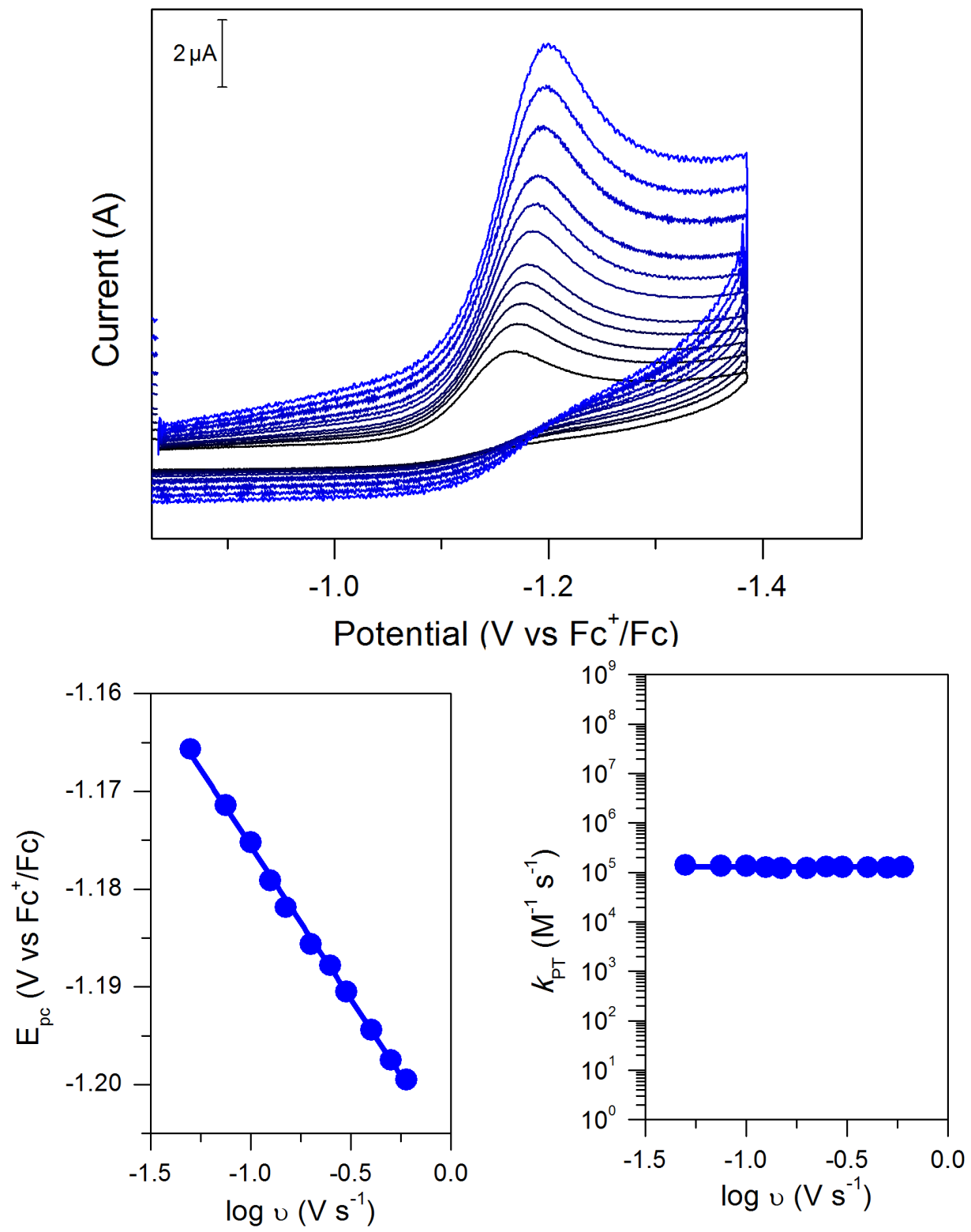

Figure S53. Determination of $\boldsymbol{k}_{\boldsymbol{P T}}^{\boldsymbol{a p p}}$ of CoCp(dcpe) with 2,3,5,6-tetrafluoro-4-CF 3 -phenol Top: cyclic voltammograms of $0.2 \mathrm{mM}\left[\mathrm{CoCp}(\mathrm{dcpe})\left(\mathrm{NCCH}_{3}\right)\right]\left[\mathrm{PF}_{6}\right]_{2}$ in $5 \mathrm{~mL}$ of $\mathrm{CH}_{3} \mathrm{CN}$ with $0.25 \mathrm{M}\left[\mathrm{Bu}_{4} \mathrm{~N}\right]\left[\mathrm{PF}_{6}\right]$ as supporting electrolyte in the presence of $0.036 \mathrm{M}$ of acid at multiple scan rates $(50,75,100,125,150,200,250,300,400,500$ and $600 \mathrm{mV} / \mathrm{s}$ from black to blue). The CVs are referenced to the ferrocenium/ferrocene couple at $0 \mathrm{~V}$.

Bottom left: evolution of the cathodic peak potential of the $\mathrm{Co}(\mathrm{II} / \mathrm{I})$ wave $\left(\mathrm{E}_{\mathrm{p}, \mathrm{c}}\right)$ with scan rate $(\mathrm{v})$. The slope is $-31 \mathrm{mV} / \mathrm{dec}$, with $\mathrm{R}^{2}=0.998$.

Bottom right: evolution of the obtained $k_{\mathrm{PT}}$ at each scan rate with scan rate. The average yields: $\boldsymbol{k}_{\boldsymbol{P T}}^{\boldsymbol{a p p}}=1.3 \times 10^{5} \mathrm{M}^{-1} \mathrm{~s}^{-1}$ 
Determination of $\boldsymbol{k}_{P T}^{a p p}$ of $\mathrm{CoCp}(\mathrm{dcpe})$ with 4- $\mathrm{CH}_{3} \mathrm{O}$-pyridinium tetrafluoroborate (pK $K_{\mathrm{a}}$ of 14.23 in $\mathrm{CH}_{3} \mathrm{CN}$ )
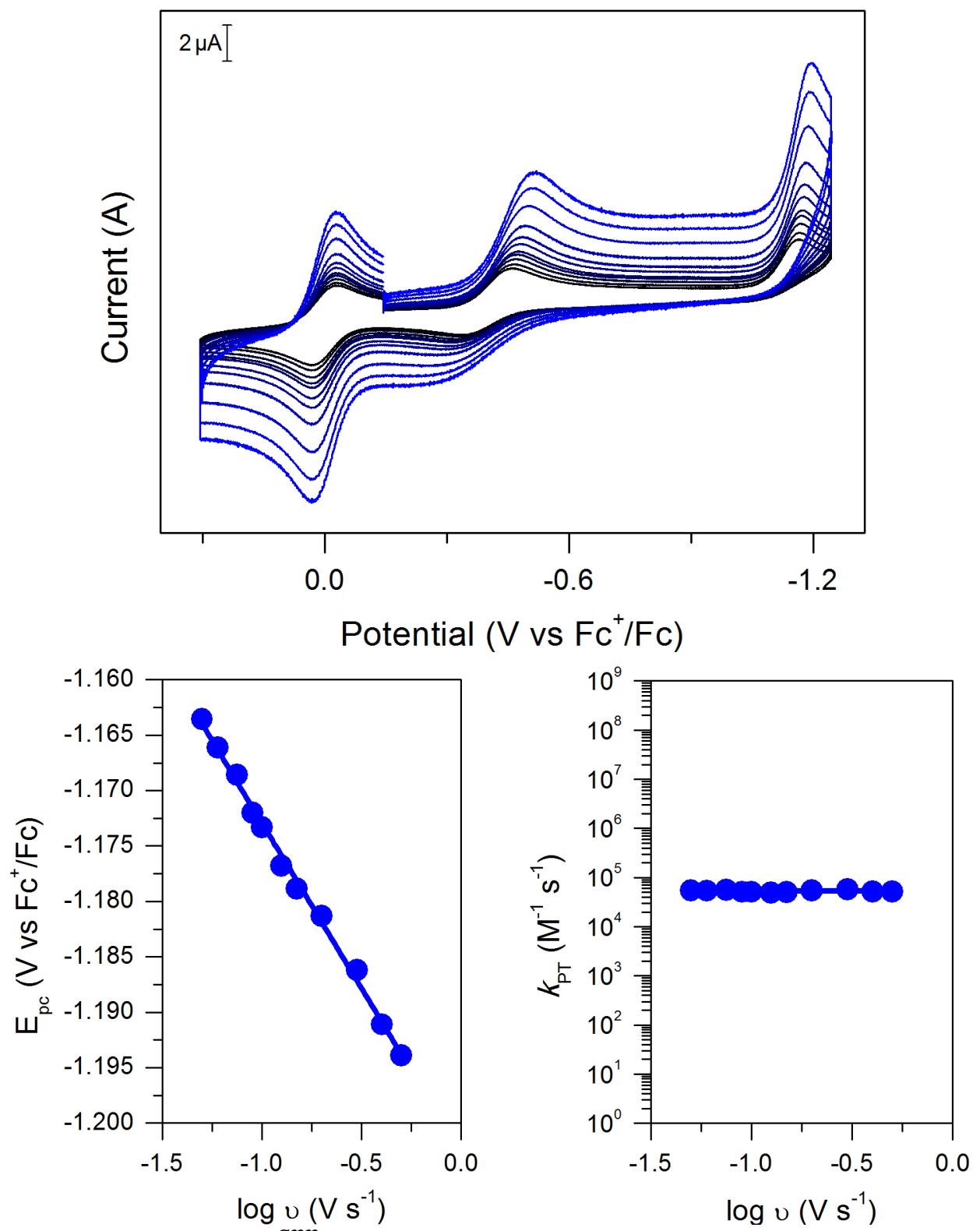

Figure S54. Determination of $\boldsymbol{k}_{\boldsymbol{P T}}^{\boldsymbol{a p p}}$ of $\mathrm{CoCp}(\mathrm{dcpe})$ with 4- $\mathrm{CH}_{3} \mathrm{O}$-pyridinium tetrafluoroborate Top: cyclic voltammograms of $0.2 \mathrm{mM}\left[\mathrm{CoCp}(\mathrm{dcpe})\left(\mathrm{NCCH}_{3}\right)\right]\left[\mathrm{PF}_{6}\right]_{2}$ in $5 \mathrm{~mL}$ of $\mathrm{CH}_{3} \mathrm{CN}$ with $0.25 \mathrm{M}\left[\mathrm{Bu}_{4} \mathrm{~N}\right]\left[\mathrm{PF}_{6}\right]$ as supporting electrolyte in the presence of $0.036 \mathrm{M}$ of acid at multiple scan rates $(50,60,75,90,100,125,150,200,300,400$ and $500 \mathrm{mV} / \mathrm{s}$ from black to blue). The CVs are referenced to the ferrocenium/ferrocene couple at $0 \mathrm{~V}$.

Bottom left: evolution of the cathodic peak potential of the $\mathrm{Co}(\mathrm{II} / \mathrm{I})$ wave $\left(\mathrm{E}_{\mathrm{p}, \mathrm{c}}\right)$ with scan rate $(\mathrm{U})$. The slope is $-31 \mathrm{mV} / \mathrm{dec}$, with $\mathrm{R}^{2}=0.998$.

Bottom right: evolution of the obtained $k_{\mathrm{PT}}$ at each scan rate with scan rate. The average yields: $\boldsymbol{k}_{\boldsymbol{P T}}^{\boldsymbol{a p p}}=5.3 \times 10^{4} \mathrm{M}^{-1} \mathrm{~s}^{-1}$ 
Determination of $k_{P T}^{a p p}$ of $\operatorname{CoCp}\left(\right.$ dcpe) with pyridinium tetrafluoroborate $\left(\mathrm{p} K_{\mathrm{a}}\right.$ of 12.53 in $\mathrm{CH}_{3} \mathrm{CN}$ )
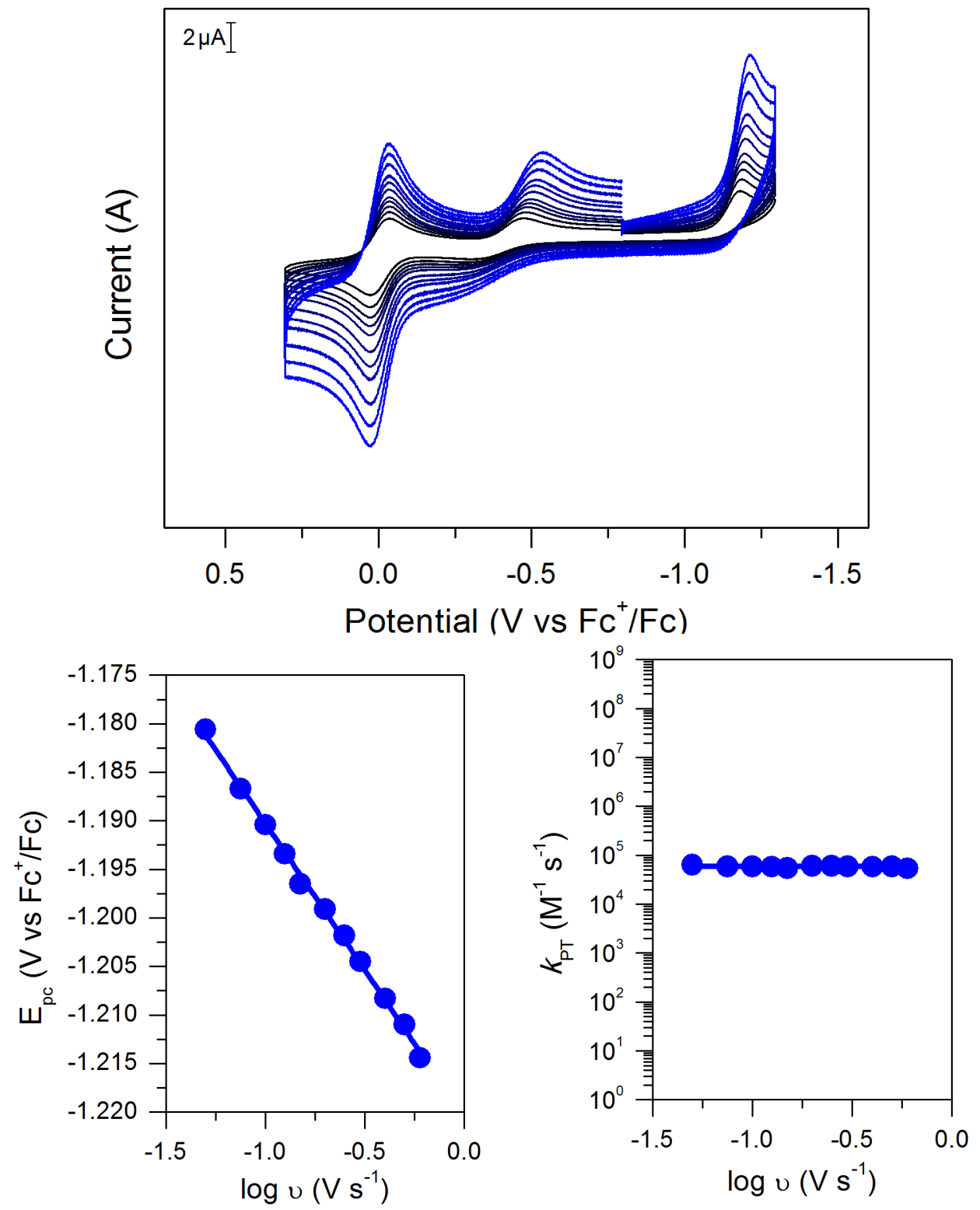

Figure S55. Determination of $\boldsymbol{k}_{\boldsymbol{P T}}^{\boldsymbol{a p p}}$ of $\mathrm{CoCp}(\mathrm{dcpe})$ with pyridinium tetrafluoroborate Top: cyclic voltammograms of $0.2 \mathrm{mM}\left[\mathrm{CoCp}(\mathrm{dcpe})\left(\mathrm{NCCH}_{3}\right)\right]\left[\mathrm{PF}_{6}\right]_{2}$ in $5 \mathrm{~mL}$ of $\mathrm{CH}_{3} \mathrm{CN}$ with $0.25 \mathrm{M}\left[\mathrm{Bu}_{4} \mathrm{~N}\right]\left[\mathrm{PF}_{6}\right]$ as supporting electrolyte in the presence of $0.047 \mathrm{M}$ of acid at multiple scan rates $(50,75,100,125,150,200,250,300,400,500$ and $600 \mathrm{mV} / \mathrm{s}$ from black to blue). The CVs are referenced to the ferrocenium/ferrocene couple at $0 \mathrm{~V}$.

Bottom left: evolution of the cathodic peak potential of the $\mathrm{Co}(\mathrm{II} / \mathrm{I})$ wave $\left(\mathrm{E}_{\mathrm{p}, \mathrm{c}}\right)$ with scan rate $(\mathrm{v})$. The slope is $-30 \mathrm{mV} / \mathrm{dec}$, with $\mathrm{R}^{2}=0.998$.

Bottom right: evolution of the obtained $k_{\mathrm{PT}}$ at each scan rate with scan rate. The average yields: $\boldsymbol{k}_{\boldsymbol{P T}}^{\boldsymbol{a p p}}=5.9 \times 10^{4} \mathrm{M}^{-1} \mathrm{~s}^{-1}$ 


\section{Determination of $k_{P T}^{a p p}$ of $\mathrm{CoCp}(\mathrm{dcpe})$ with $4-{ }^{t} \mathrm{Bu}-\mathrm{pyridinium}$ tetrafluoroborate $\left(\mathrm{p} K_{\mathrm{a}}\right.$ of 11.1}

in $\mathrm{CH}_{3} \mathrm{CN}$ )
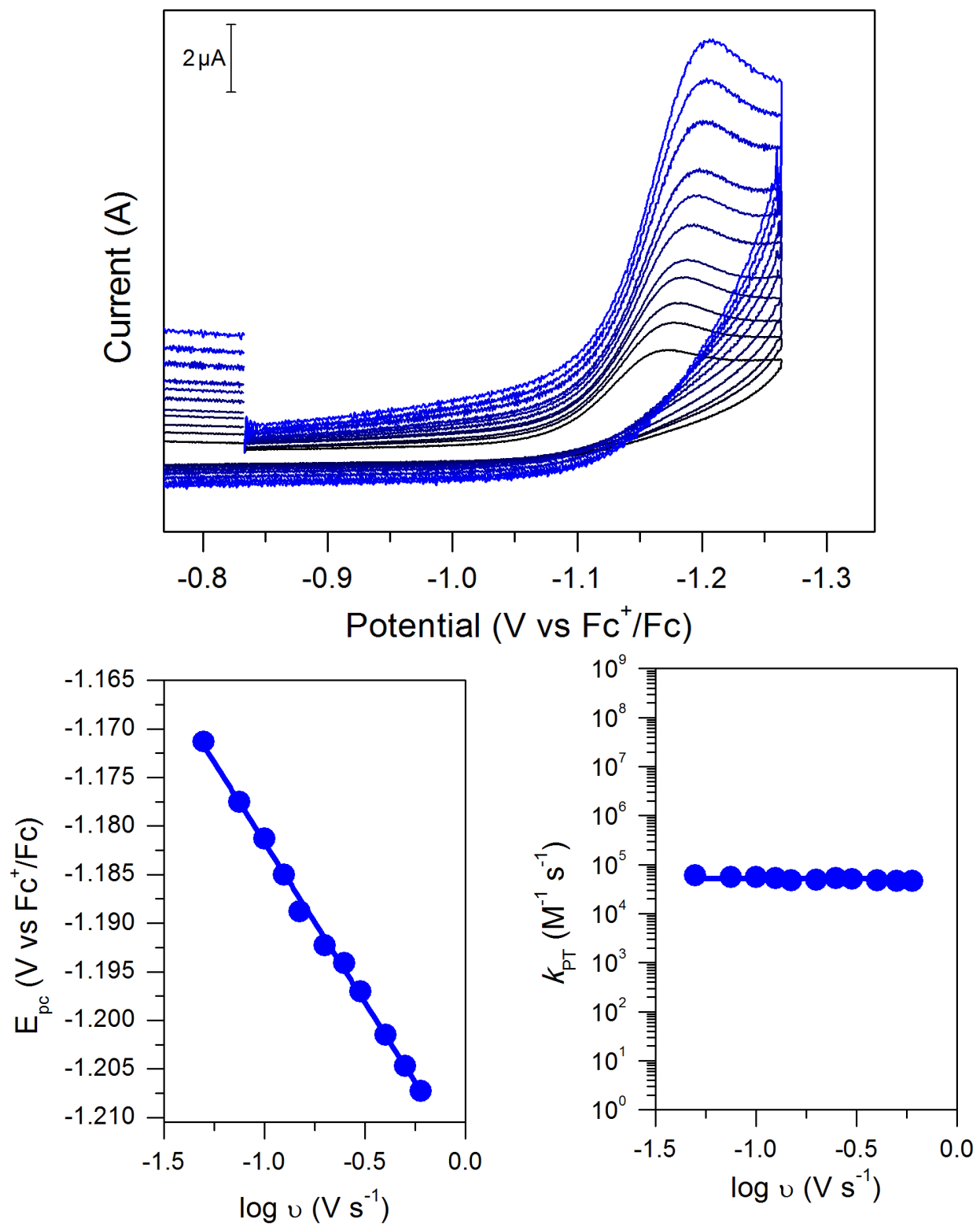

Figure S56. Determination of $\boldsymbol{k}_{\boldsymbol{P T}}^{\boldsymbol{a p p}}$ of CoCp(dcpe) with 4- ${ }^{t} \mathrm{Bu}-\mathrm{pyridinium}$ tetrafluoroborate Top: cyclic voltammograms of $0.2 \mathrm{mM}\left[\mathrm{CoCp}(\mathrm{dcpe})\left(\mathrm{NCCH}_{3}\right)\right]\left[\mathrm{PF}_{6}\right]_{2}$ in $5 \mathrm{~mL}$ of $\mathrm{CH}_{3} \mathrm{CN}$ with $0.25 \mathrm{M}\left[\mathrm{Bu}_{4} \mathrm{~N}\right]\left[\mathrm{PF}_{6}\right]$ as supporting electrolyte in the presence of $0.050 \mathrm{M}$ of acid at multiple scan rates $(50,75,100,125,150,200,250,300,400,500$ and $600 \mathrm{mV} / \mathrm{s}$ from black to blue). The CVs are referenced to the ferrocenium/ferrocene couple at $0 \mathrm{~V}$.

Bottom left: evolution of the cathodic peak potential of the $\mathrm{Co}(\mathrm{II} / \mathrm{I})$ wave $\left(\mathrm{E}_{\mathrm{p}, \mathrm{c}}\right)$ with scan rate $(\mathrm{U})$. The slope is $-33 \mathrm{mV} / \mathrm{dec}$, with $\mathrm{R}^{2}=0.998$.

Bottom right: evolution of the obtained $k_{\mathrm{PT}}$ at each scan rate with scan rate. The average yields: $\boldsymbol{k}_{\boldsymbol{P T}}^{\boldsymbol{a p p}}=5.2 \times 10^{4} \mathrm{M}^{-1} \mathrm{~s}^{-1}$ 
Determination of $k_{P T}^{a p p}$ of $\mathrm{CoCp}(\mathrm{dcpe})$ with anilinium tetra-fluoroborate $\left(\mathrm{p} K_{\mathrm{a}}\right.$ of 10.62 in $\mathrm{CH}_{3} \mathrm{CN}$ )
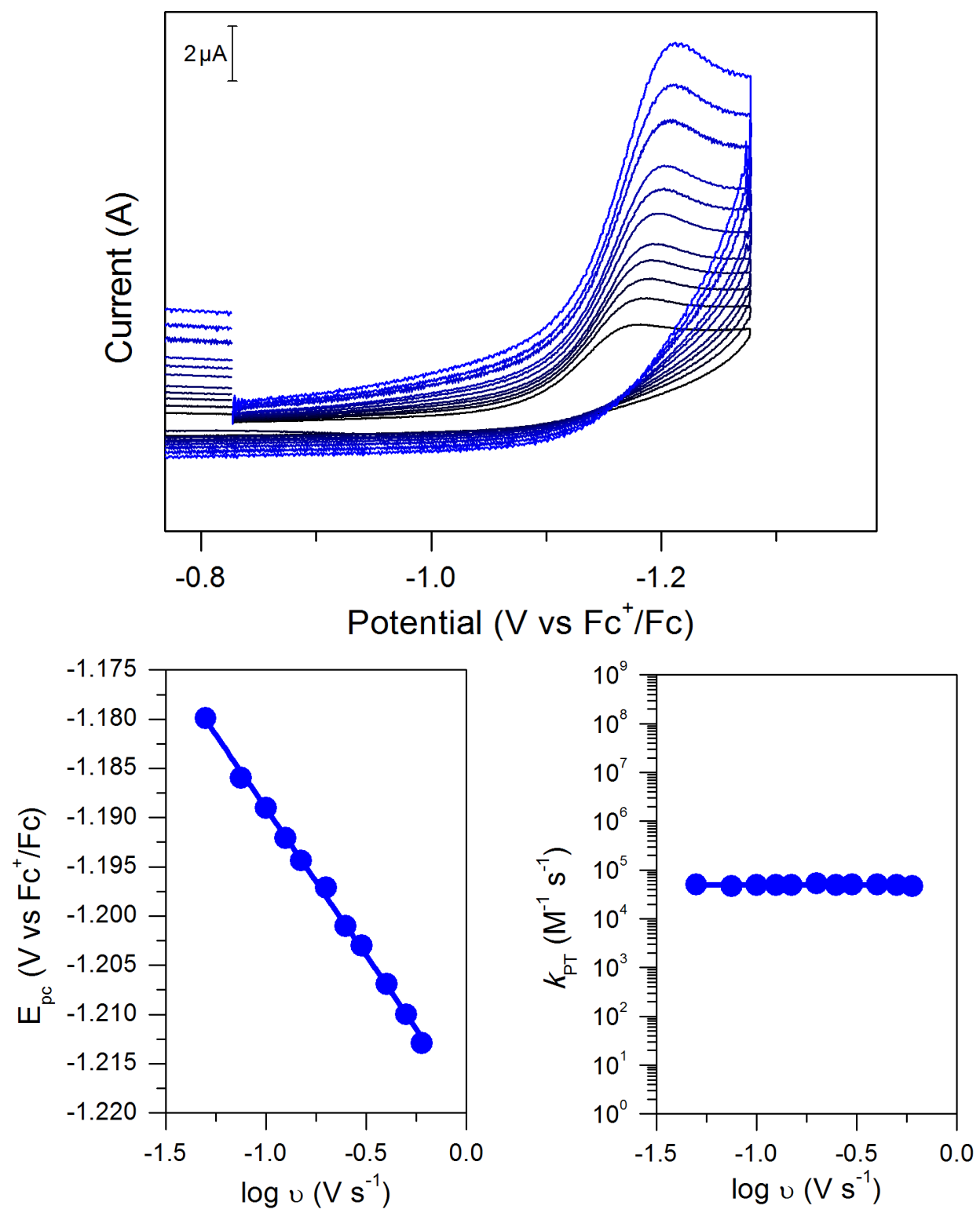

Figure S57. Determination of $\boldsymbol{k}_{\boldsymbol{P T}}^{\boldsymbol{a p p}}$ of CoCp(dcpe) with anilinium tetrafluoroborate Top: cyclic voltammograms of $0.2 \mathrm{mM}\left[\mathrm{CoCp}(\mathrm{dcpe})\left(\mathrm{NCCH}_{3}\right)\right]\left[\mathrm{PF}_{6}\right]_{2}$ in $5 \mathrm{~mL}$ of $\mathrm{CH}_{3} \mathrm{CN}$ with $0.25 \mathrm{M}\left[\mathrm{Bu}_{4} \mathrm{~N}\right]\left[\mathrm{PF}_{6}\right]$ as supporting electrolyte in the presence of $0.054 \mathrm{M}$ of acid at multiple scan rates $(50,75,100,125,150,200,250,300,400,500$ and $600 \mathrm{mV} / \mathrm{s}$ from black to blue). The CVs are referenced to the ferrocenium/ferrocene couple at $0 \mathrm{~V}$.

Bottom left: evolution of the cathodic peak potential of the $\mathrm{Co}(\mathrm{II} / \mathrm{I})$ wave $\left(\mathrm{E}_{\mathrm{p}, \mathrm{c}}\right)$ with scan rate (v). The slope is $-30 \mathrm{mV} / \mathrm{dec}$, with $\mathrm{R}^{2}=0.998$.

Bottom right: evolution of the obtained $k_{\mathrm{PT}}$ at each scan rate with scan rate. The average yields: $\boldsymbol{k}_{\boldsymbol{P T}}^{\boldsymbol{a p p}}=4.9 \times 10^{4} \mathrm{M}^{-1} \mathrm{~s}^{-1}$ 
Determination of $k_{P T}^{a p p}$ of $\mathrm{CoCp}(\mathrm{dcpe})$ with 4-Br-anilinium tetrafluoroborate $\left(\mathrm{p} K_{\mathrm{a}}\right.$ of 9.43 in $\mathrm{CH}_{3} \mathrm{CN}$ )
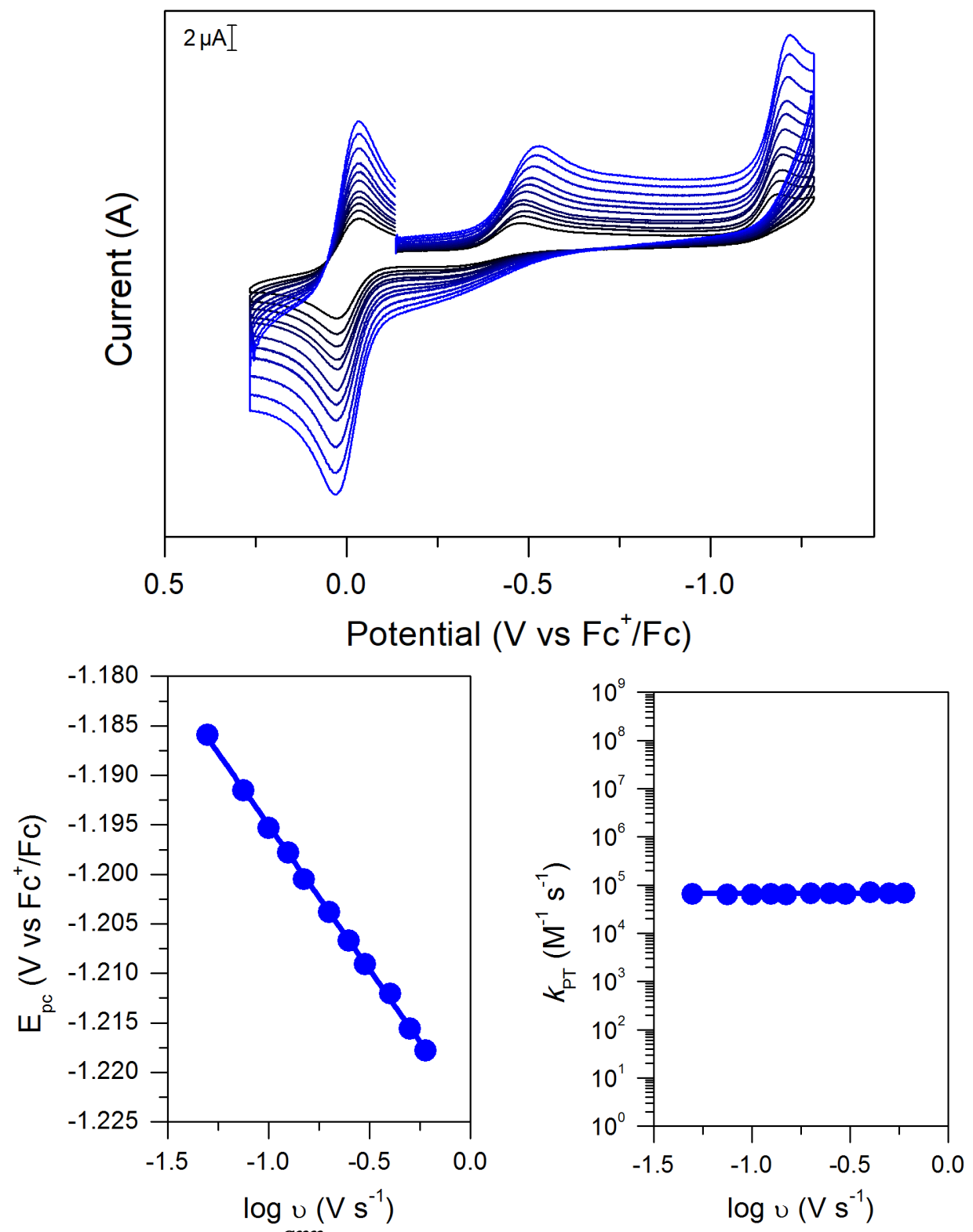

Figure S58. Determination of $\boldsymbol{k}_{\boldsymbol{P T}}^{\boldsymbol{a p p}}$ of $\mathrm{CoCp}(\mathrm{dcpe})$ with 4-Br-anilinium tetrafluoroborate Top: cyclic voltammograms of $0.2 \mathrm{mM}\left[\mathrm{CoCp}(\mathrm{dcpe})\left(\mathrm{NCCH}_{3}\right)\right]\left[\mathrm{PF}_{6}\right]_{2}$ in $5 \mathrm{~mL}$ of $\mathrm{CH}_{3} \mathrm{CN}$ with $0.25 \mathrm{M}\left[\mathrm{Bu}_{4} \mathrm{~N}\right]\left[\mathrm{PF}_{6}\right]$ as supporting electrolyte in the presence of $0.026 \mathrm{M}$ of acid at multiple scan rates $(50,75,100,125,150,200,250,300,400,500$ and $600 \mathrm{mV} / \mathrm{s}$ from black to blue). The CVs are referenced to the ferrocenium/ferrocene couple at $0 \mathrm{~V}$.

Bottom left: evolution of the cathodic peak potential of the $\mathrm{Co}(\mathrm{II} / \mathrm{I})$ wave $\left(\mathrm{E}_{\mathrm{p}, \mathrm{c}}\right)$ with scan rate $(\mathrm{v})$. The slope is $-29 \mathrm{mV} / \mathrm{dec}$, with $\mathrm{R}^{2}=0.999$.

Bottom right: evolution of the obtained $k_{\mathrm{PT}}$ at each scan rate with scan rate. The average yields: $\boldsymbol{k}_{P T}^{\boldsymbol{a p p}}=6.6 \times 10^{4} \mathrm{M}^{-1} \mathrm{~s}^{-1}$ 


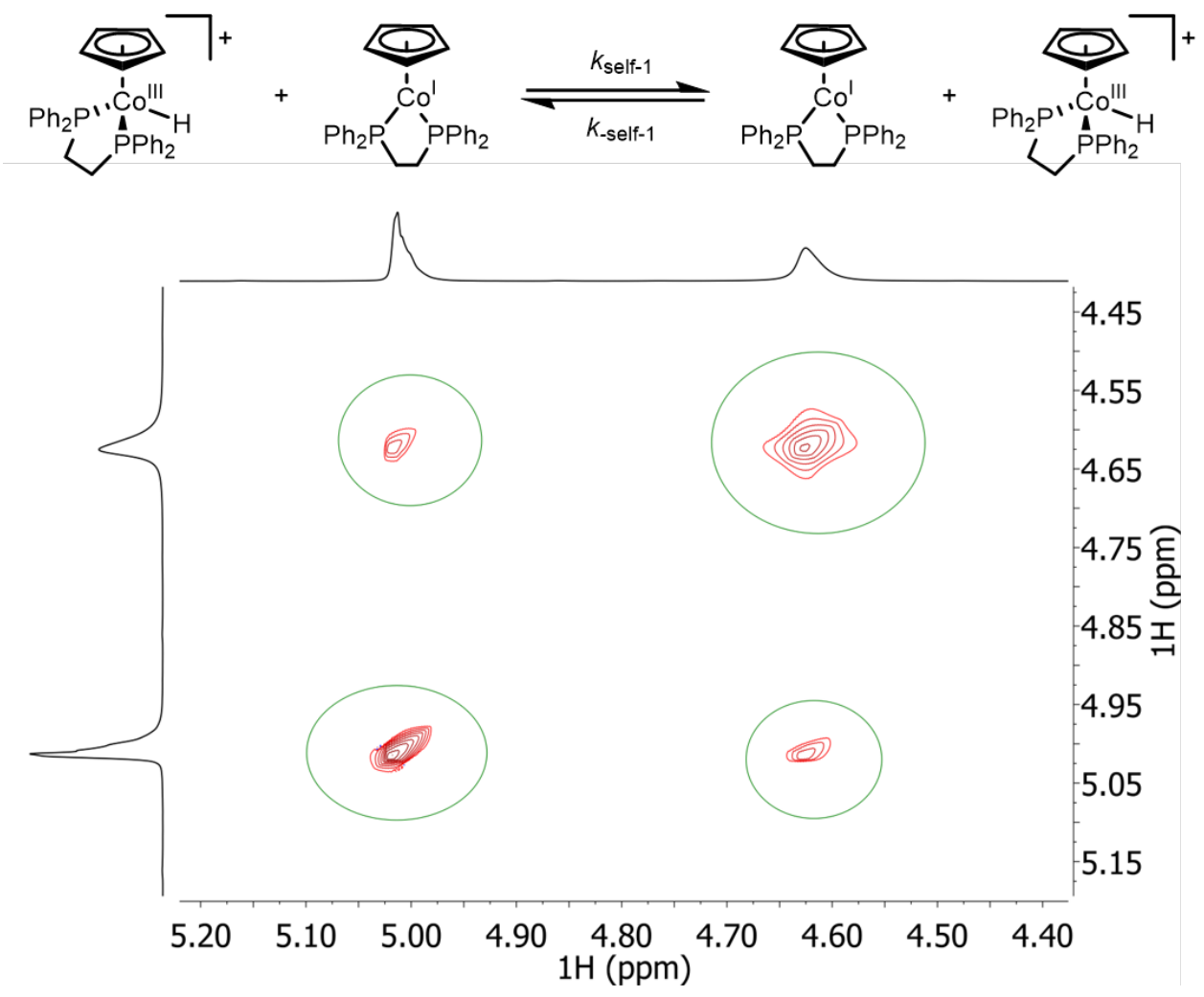

Figure S59. 2D EXSY ${ }^{1} \mathrm{H}-\mathrm{NMR}$ spectrum shows chemical exchange between CoCp(dppe) (107 $\mathrm{mm})$ and $[\mathrm{HCoCp}(\mathrm{dppe})]\left[\mathrm{PF}_{6}\right](119 \mathrm{mM})$ in $50: 50 \mathrm{C}_{6} \mathrm{D}_{6}: \mathrm{CD}_{3} \mathrm{CN}$ at $298 \mathrm{~K}$. The spectrum was collected with relaxation time of $15 \mathrm{~s}$ and mixing time $t_{\mathrm{m}}=0.1 \mathrm{~s}$. The exchange phenomena were confirmed from the in-phase cross peaks of the $\mathrm{Cp}$ resonances. The first-order exchange rate was obtained according to equation $\boldsymbol{k}_{\text {obs }}=\frac{1}{t_{m}} \ln \frac{r+1}{r-1}$, where $r=4 X_{C o^{I}} X_{H C o^{I I I}} \frac{I_{C o^{I}}+I_{H C O} I I I}{I_{C o^{I} \rightarrow H C o^{I I I}+I_{H C o} I I \rightarrow C o^{I}}}-$ $\left(\boldsymbol{X}_{\boldsymbol{C o}^{I}}-\boldsymbol{X}_{\boldsymbol{H} \boldsymbol{C o}} \boldsymbol{I I I}^{2}\right)^{2}$, following literature approach. ${ }^{2,3}$ In this equation, $k_{\mathrm{obs}}=k_{\text {self- }-1}[\mathrm{CoCp}(\mathrm{dppe})]+k$ self-1 $\left[[\mathrm{HCoCp}(\mathrm{dppe})]\left[\mathrm{PF}_{6}\right]\right] ; \boldsymbol{X}_{\boldsymbol{C o}} \boldsymbol{I}^{\boldsymbol{I}}$ and $\boldsymbol{X}_{\boldsymbol{H} \boldsymbol{C o}^{\boldsymbol{I I I}}}$ represent the mole fractions of CoCp(dppe) and $[\mathrm{HCoCp}(\mathrm{dppe})]\left[\mathrm{PF}_{6}\right]$, respectively; $\boldsymbol{I}_{\boldsymbol{C} \boldsymbol{o}^{\boldsymbol{I}}}$ and $\boldsymbol{I}_{\boldsymbol{H} \boldsymbol{C} \boldsymbol{o}^{\boldsymbol{I I I}}}$ represent the integration of the on-diagonal peaks; $\boldsymbol{I}_{\boldsymbol{C o}}{ }^{\boldsymbol{I}} \rightarrow \boldsymbol{H C} \boldsymbol{o}^{I I I}$ and $\boldsymbol{I}_{\boldsymbol{H C} \boldsymbol{O}^{I I I} \rightarrow \boldsymbol{C o}} \boldsymbol{o}^{I}$ represent the integrations of the off-diagonal peaks. The secondorder exchange rate constant was calculated by dividing by the concentrations of $\mathrm{CoCp}(\mathrm{dppe})$ and $[\mathrm{HCoCp}(\mathrm{dppe})]\left[\mathrm{PF}_{6}\right]$. This yields $\underline{k}_{\text {self- } 1}=k_{\text {-self- }-1}=3.1 \mathrm{M}^{-1} \mathrm{~s}^{-1}$. 

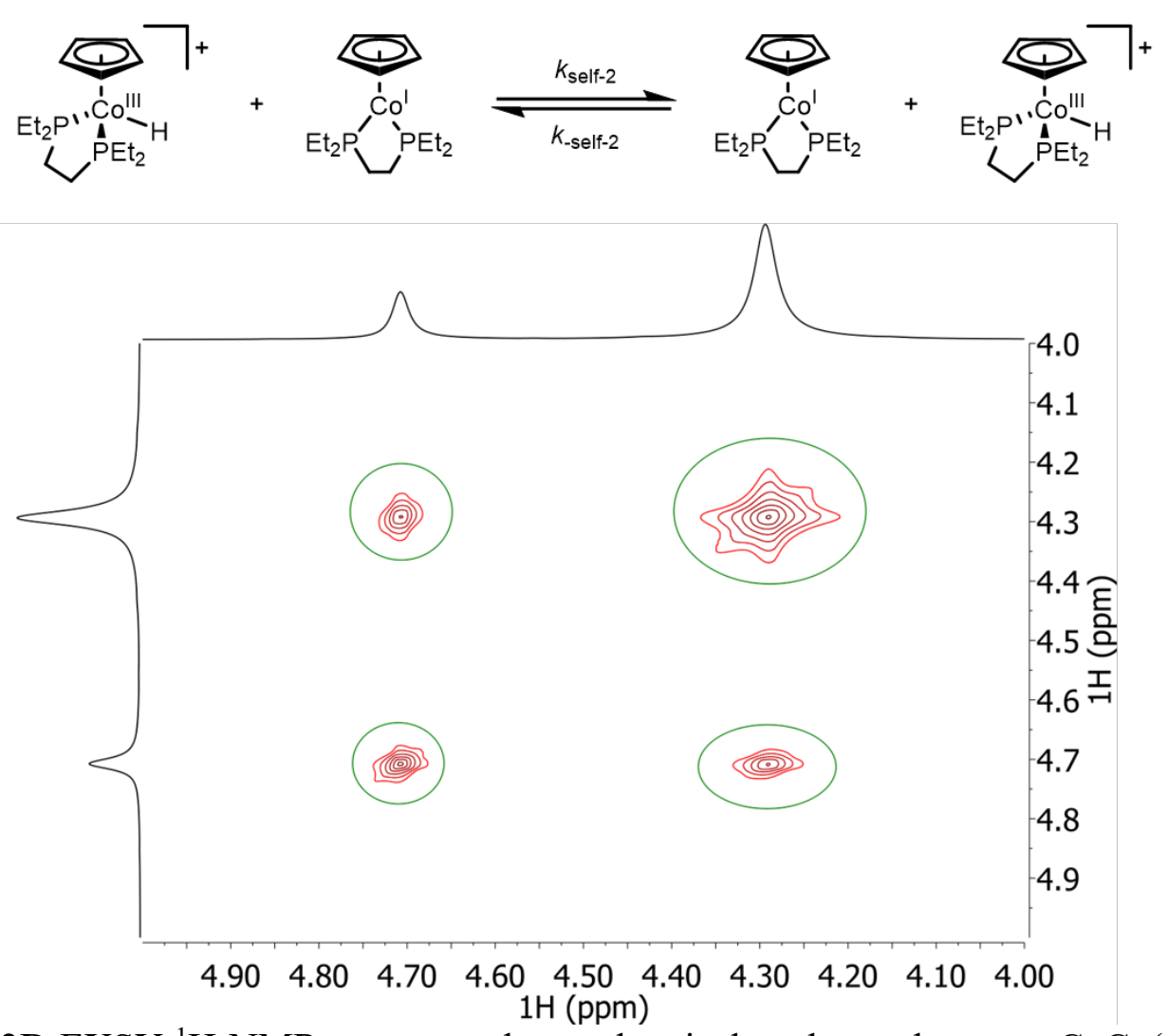

Figure S60. 2D EXSY ${ }^{1} \mathrm{H}-\mathrm{NMR}$ spectrum shows chemical exchange between $\mathrm{CoCp}(\mathrm{depe})$ (101 $\mathrm{mm})$ and $[\mathrm{HCoCp}($ depe $)]\left[\mathrm{PF}_{6}\right](31.7 \mathrm{mM})$ in $50: 50 \mathrm{C}_{6} \mathrm{D}_{6}: \mathrm{CD}_{3} \mathrm{CN}$ at $298 \mathrm{~K}$. The spectrum was collected with relaxation time of $2 \mathrm{~s}$ and mixing time $t_{\mathrm{m}}=0.05 \mathrm{~s}$. The exchange phenomena were confirmed from the in-phase cross peaks of the $\mathrm{Cp}$ resonances. The first-order exchange rate was

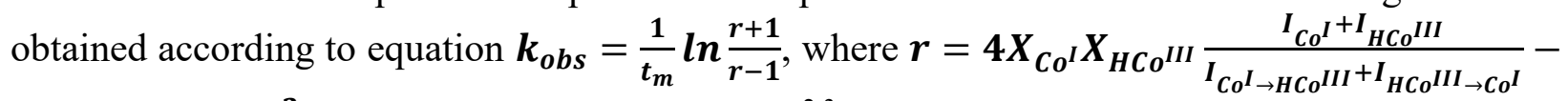
$\left(\boldsymbol{X}_{\boldsymbol{C o}} \boldsymbol{I}-\boldsymbol{X}_{\boldsymbol{H C o}} \boldsymbol{I I I I}^{2}\right.$, following literature approach. ${ }^{2,3}$ In this equation, $k_{\mathrm{obs}}=k_{\mathrm{self}-2}[\mathrm{CoCp}(\mathrm{depe})]+$ $k_{- \text {self-2 }}\left[[\mathrm{HCoCp}(\right.$ depe $\left.)]\left[\mathrm{PF}_{6}\right]\right] ; \boldsymbol{X}_{\boldsymbol{C o}}{ }^{\boldsymbol{I}}$ and $\boldsymbol{X}_{\boldsymbol{H} \boldsymbol{C o}}{ }^{I I I} \boldsymbol{I}$ represent the mole fractions of CoCp(depe) and $[\mathrm{HCoCp}(\mathrm{depe})]\left[\mathrm{PF}_{6}\right]$, respectively; $\boldsymbol{I}_{\boldsymbol{C o}} \boldsymbol{I}$ and $\boldsymbol{I}_{\boldsymbol{H C o}}{ }^{I I I}$ represent the integration of the on-diagonal

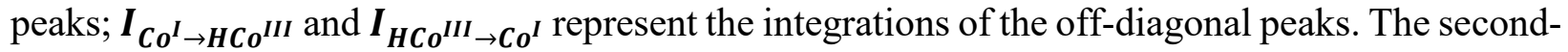
order exchange rate constant was calculated by dividing by the concentrations of $\mathrm{CoCp}(\mathrm{depe})$ and $[\mathrm{HCoCp}($ depe $)]\left[\mathrm{PF}_{6}\right]$. This yields $\underline{k_{\text {self-2 }}=k_{- \text {self-2 }}=61 \mathrm{M}^{-1} \mathrm{~s}^{-1}}$. 

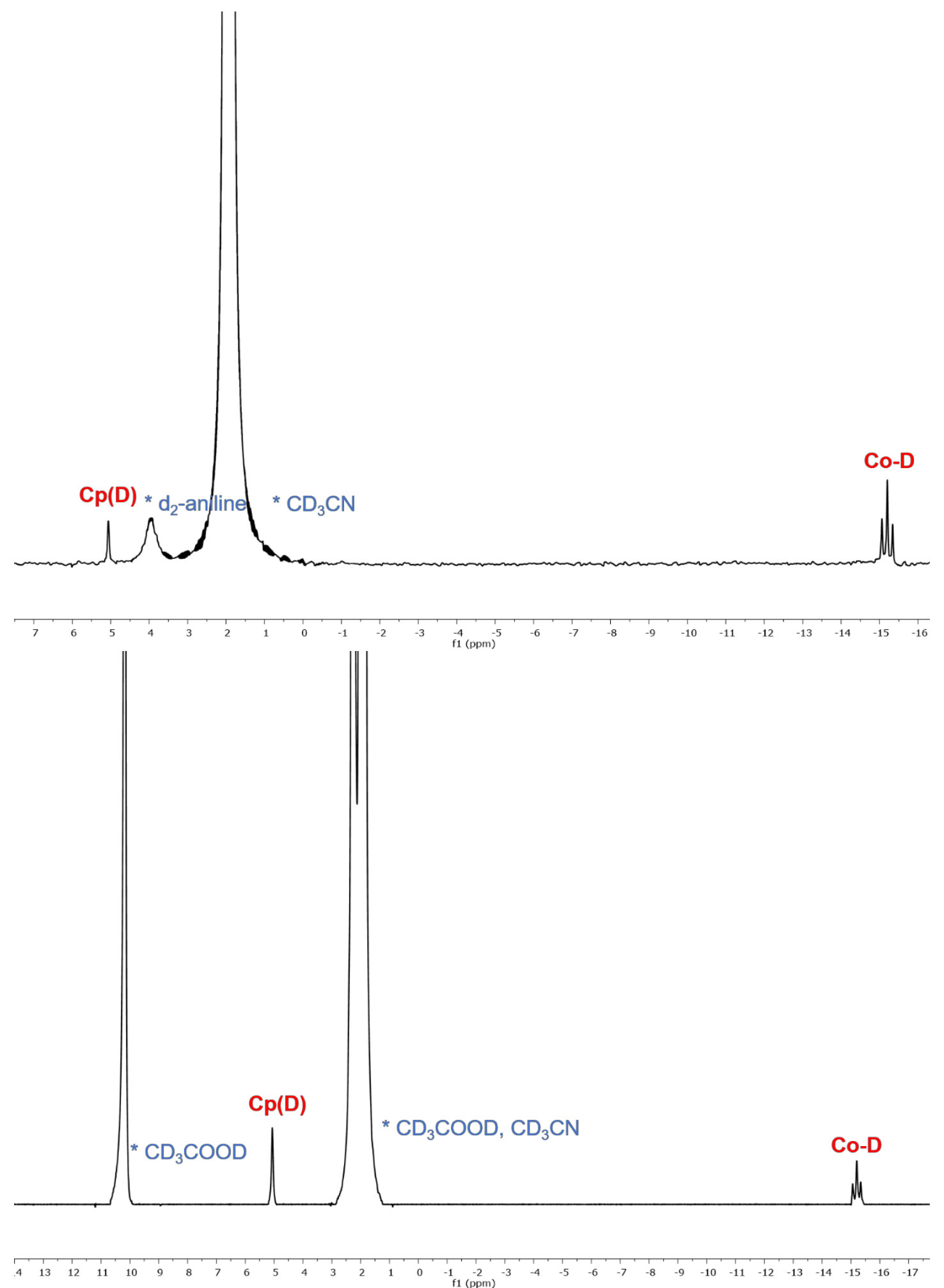

Figure S61. ${ }^{2} \mathrm{H}-\mathrm{NMR}$ after treatment of $\left[\mathrm{CpCo}^{\mathrm{I}}(\mathrm{dppe})\right]$ with 1 eq. $d_{3}$-anilinium hexaflurophosphate (top) and 10 eq. $\mathrm{CD}_{3} \mathrm{COOD}$ (bottom). In both cases deuterium incorporation in the cyclopentadienyl ring is observed. 


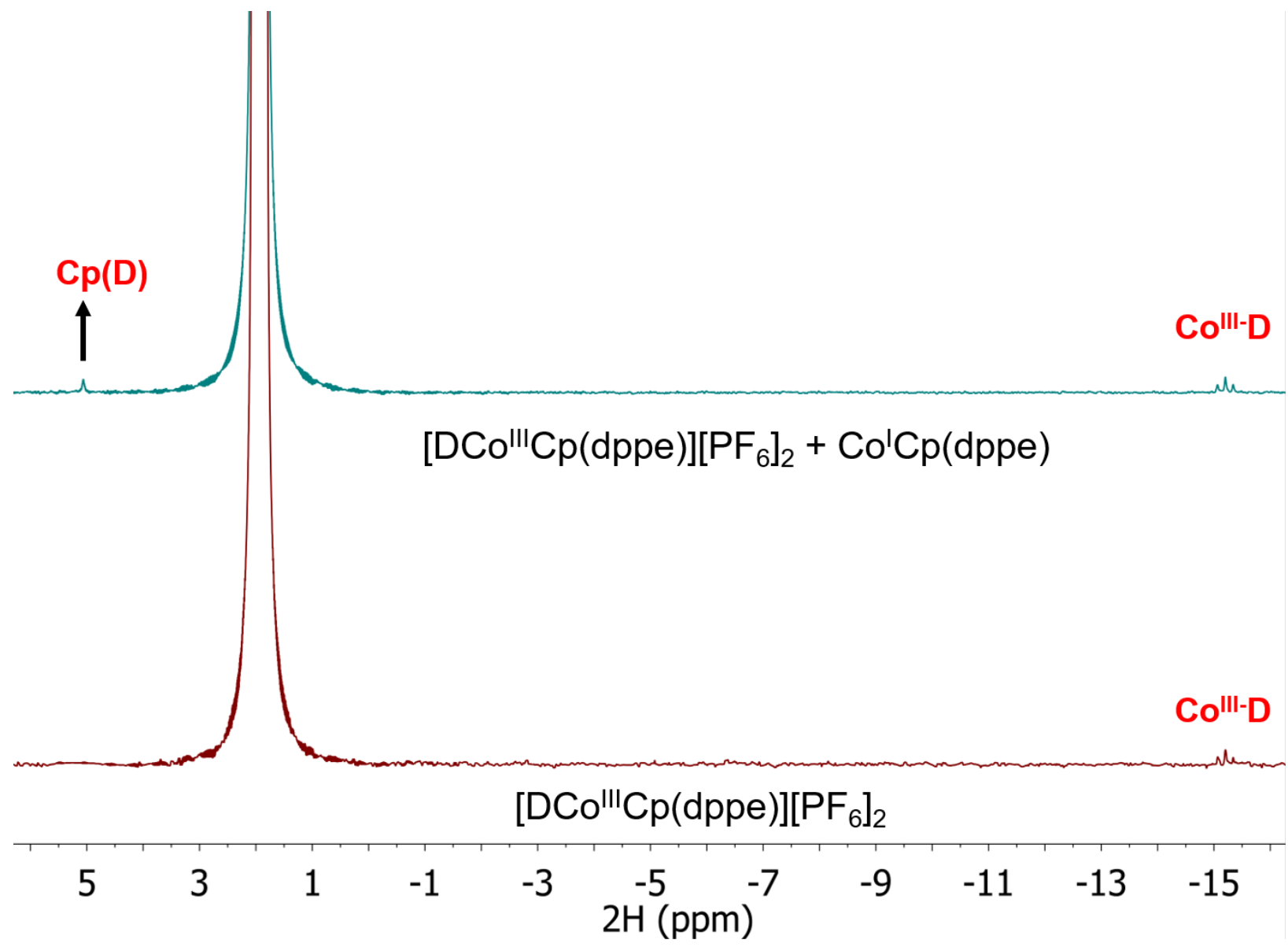

Figure S62. ${ }^{2} \mathrm{H}$ NMR of $[\mathrm{DCoCp}(\mathrm{dppe})]\left[\mathrm{PF}_{6}\right]$ (bottom) and $\left[\mathrm{DCo}^{\mathrm{III}} \mathrm{Cp}(\mathrm{dppe})\right]\left[\mathrm{PF}_{6}\right]$ with 1 eq. $\mathrm{CoCp}$ (dppe) (top). While there is no $\mathrm{CpD}$ resonance in the former, the latter shows this $\mathrm{CpD}$ resonance. 

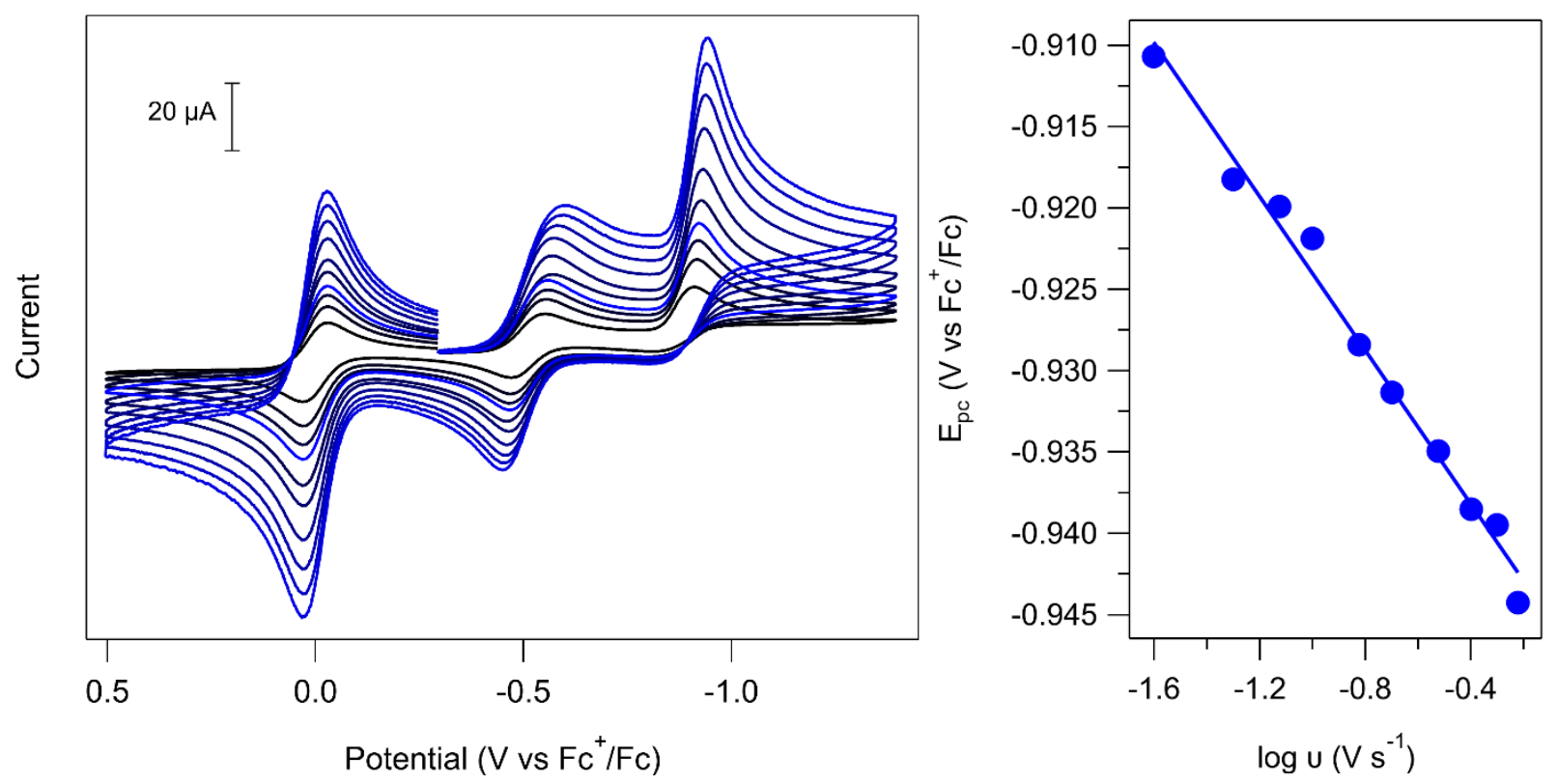

Figure S63. Cyclic voltammograms used to determine $k_{\mathrm{D}}$ for reaction of CoCp(dppe) with $\mathrm{CD}_{3} \mathrm{COOD}$
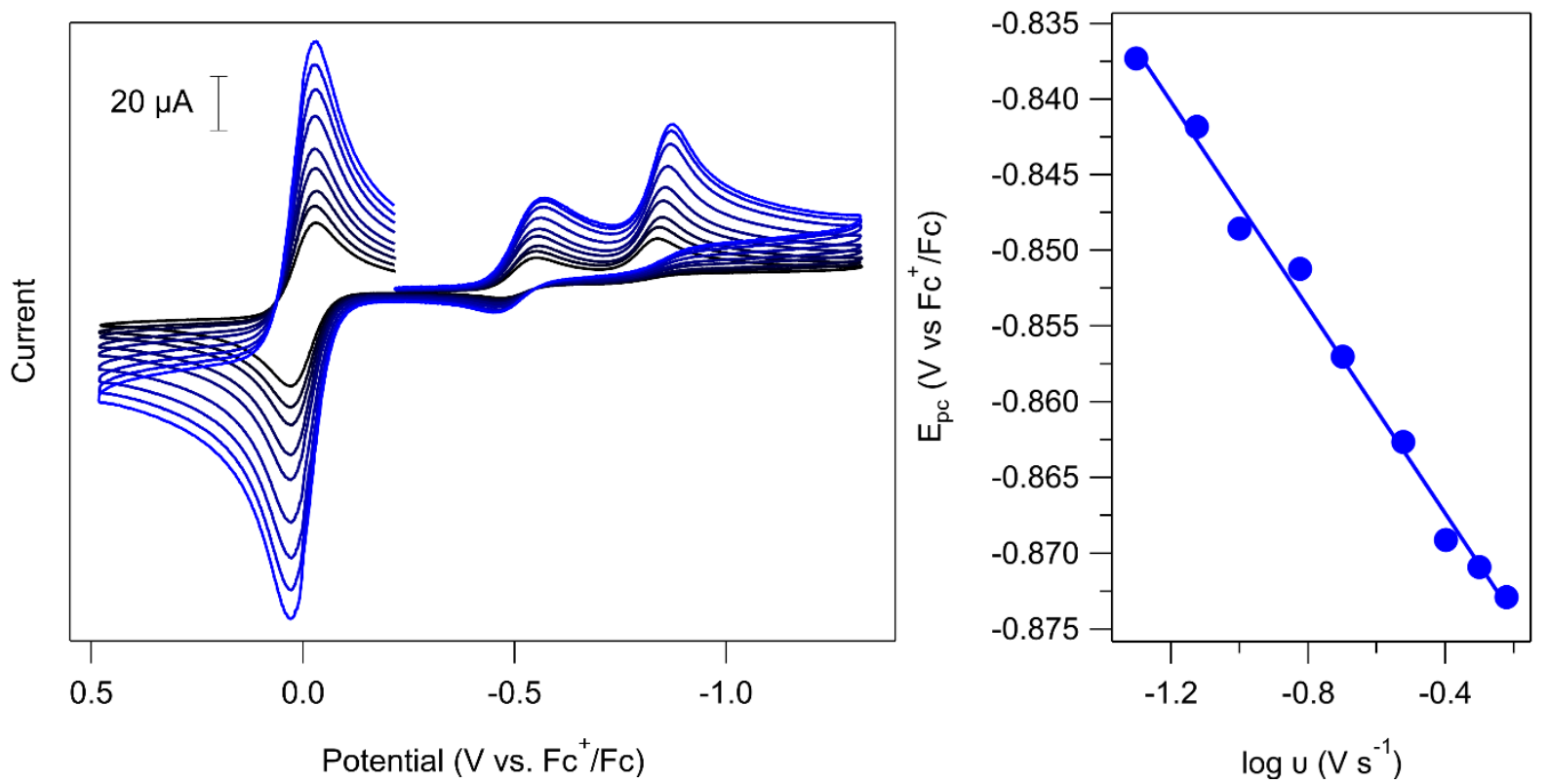

Figure S64. Cyclic voltammograms used to determine $k_{\mathrm{H}}$ for reaction of $\mathrm{CoCp}(\mathrm{dppe})$ with anilinium. 

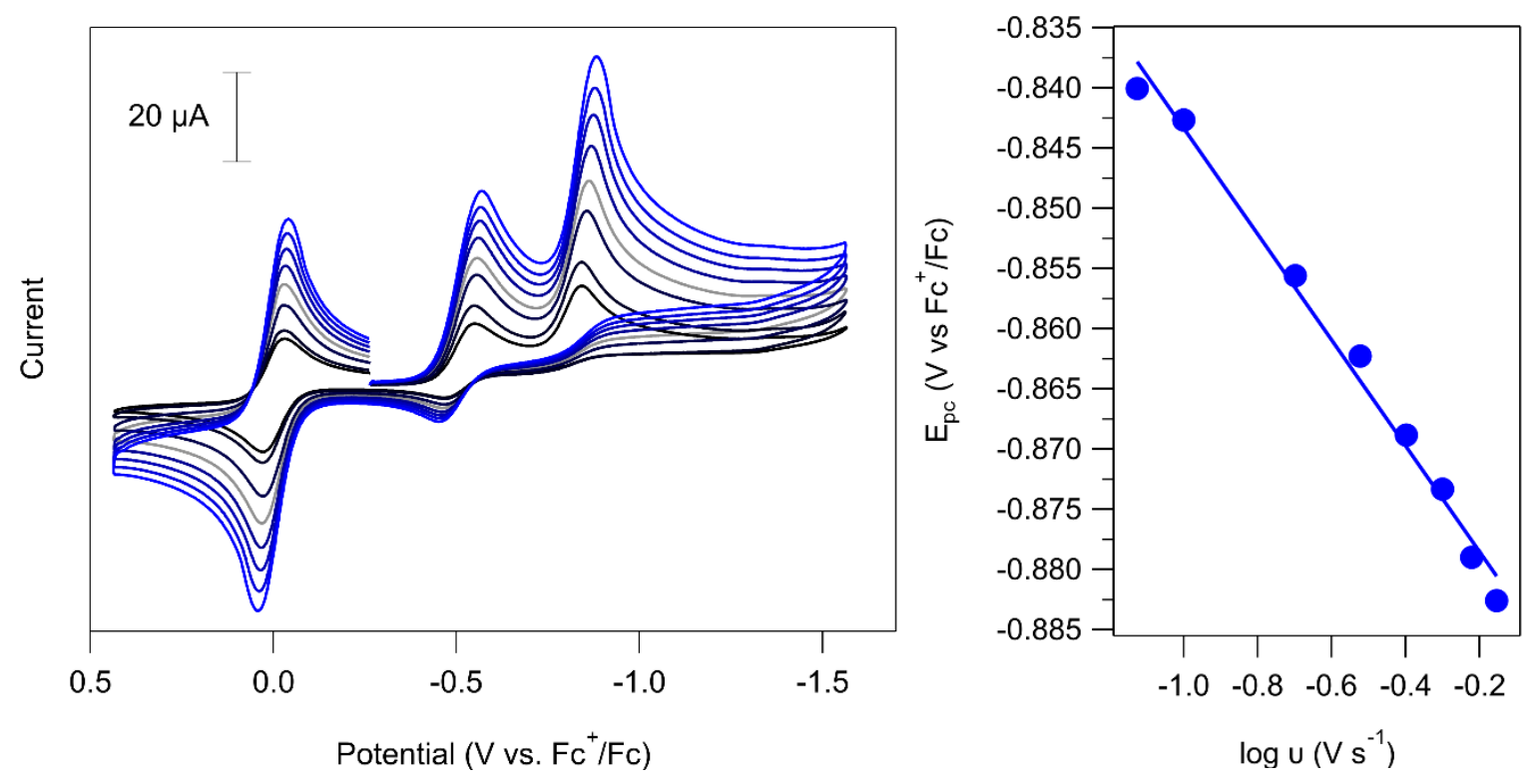

Figure S65. Cyclic voltammograms used to determine $k_{\mathrm{D}}$ for reaction of CoCp(dppe) with $d_{3}$ anilinium 


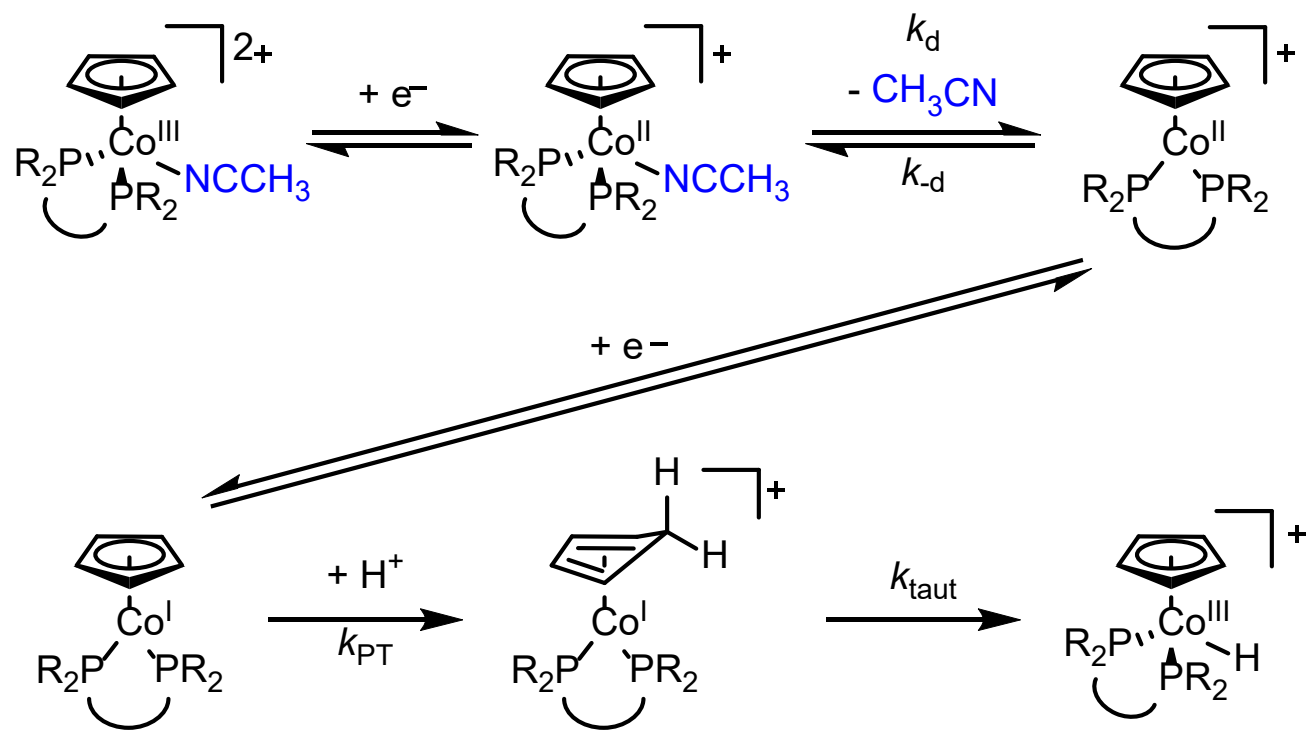

$\left[\mathrm{Co}^{\mathrm{III}} \mathrm{Cp}(\mathrm{dppe})\left(\mathrm{NCCH}_{3}\right)\right]^{2+}+\mathrm{e}^{-}=\left[\mathrm{Co}^{\mathrm{II}} \mathrm{Cp}(\mathrm{dppe})\left(\mathrm{NCCH}_{3}\right)\right]^{+}$

with $\mathrm{E}_{1 / 2}=-0.51 \mathrm{~V}\left(\mathrm{vs} \mathrm{Fc}^{+} / \mathrm{Fc}\right), k_{\mathrm{s}}=0.051 \mathrm{~cm} / \mathrm{s}, \mathrm{D}=3.4 \times 10^{-6} \mathrm{~cm}^{2} / \mathrm{s}$

$\left[\mathrm{Co}^{\mathrm{II}} \mathrm{Cp}(\mathrm{dppe})\left(\mathrm{NCCH}_{3}\right)\right]^{+}=\left[\mathrm{Co}{ }^{\mathrm{II}} \mathrm{Cp}(\text { dppe })\right]^{+}+\mathrm{CH}_{3} \mathrm{CN}$

with $k_{\mathrm{d}}=4 \times 10^{7} \mathrm{~s}^{-1}, K_{\text {eq }}=76 \mathrm{M}$

$\left[\mathrm{Co}{ }^{\mathrm{II}} \mathbf{C p}(\mathrm{dppe})\right]^{+}+\mathrm{e}^{-}=\mathbf{C o}^{\mathrm{I}} \mathbf{C p}(\mathrm{dppe})$

with $\mathrm{E}_{1 / 2}=-0.93 \mathrm{~V}\left(\mathrm{vs} \mathrm{Fc}^{+} / \mathrm{Fc}\right), k_{\mathrm{s}}=0.11 \mathrm{~cm} / \mathrm{s}, \mathrm{D}=5.2 \times 10^{-6} \mathrm{~cm}^{2} / \mathrm{s}$

$\mathrm{Co}^{\mathrm{I}} \mathrm{Cp}(\mathrm{dppe})+\mathrm{HA}=\left[\mathrm{Co}^{\mathrm{I}}(\mathbf{C p H})(\mathrm{dppe})\right]^{+}+\mathrm{A}^{-}$

with $K_{\mathrm{PT}}$ varying from $1 \times 10^{-8}-1 \times 10^{8}, k_{\mathrm{PT}}$ varying from $1 \times 10^{2}-1 \times 10^{10} \mathrm{M}^{-1} \mathrm{~s}^{-1}$

\section{$\left[\mathrm{Co}^{\mathrm{I}}(\mathrm{CpH})(\mathrm{dppe})\right]^{+} \rightarrow\left[\mathrm{HCo}^{\mathrm{III}} \mathrm{Cp}(\mathrm{dppe})\right]^{+}$ \\ with $k_{\text {taut }}=1 \times 10^{14} \mathrm{~s}^{-1}$}

Scheme S1. (top) $\mathrm{EC}_{1} \mathrm{EC}_{2} \mathrm{C}_{3}$ reaction mechanism describing the reaction of $\left[\mathrm{CoCp}(\mathrm{dppe})\left(\mathrm{NCCH}_{3}\right)\right]^{2+}$ to form $[\mathrm{HCoCp}(\mathrm{dppe})]^{+}$. (bottom) Expressions describing the elementary reaction steps, along with parameters employed for digital simulations (unless otherwise stated in figure caption), of voltammograms in $\mathrm{CH}_{3} \mathrm{CN}$, where the concentration of $\mathrm{CH}_{3} \mathrm{CN}$ is taken as $19 \mathrm{M}$. Scan rate and concentrations provided in figure captions of individual digital simulation. 


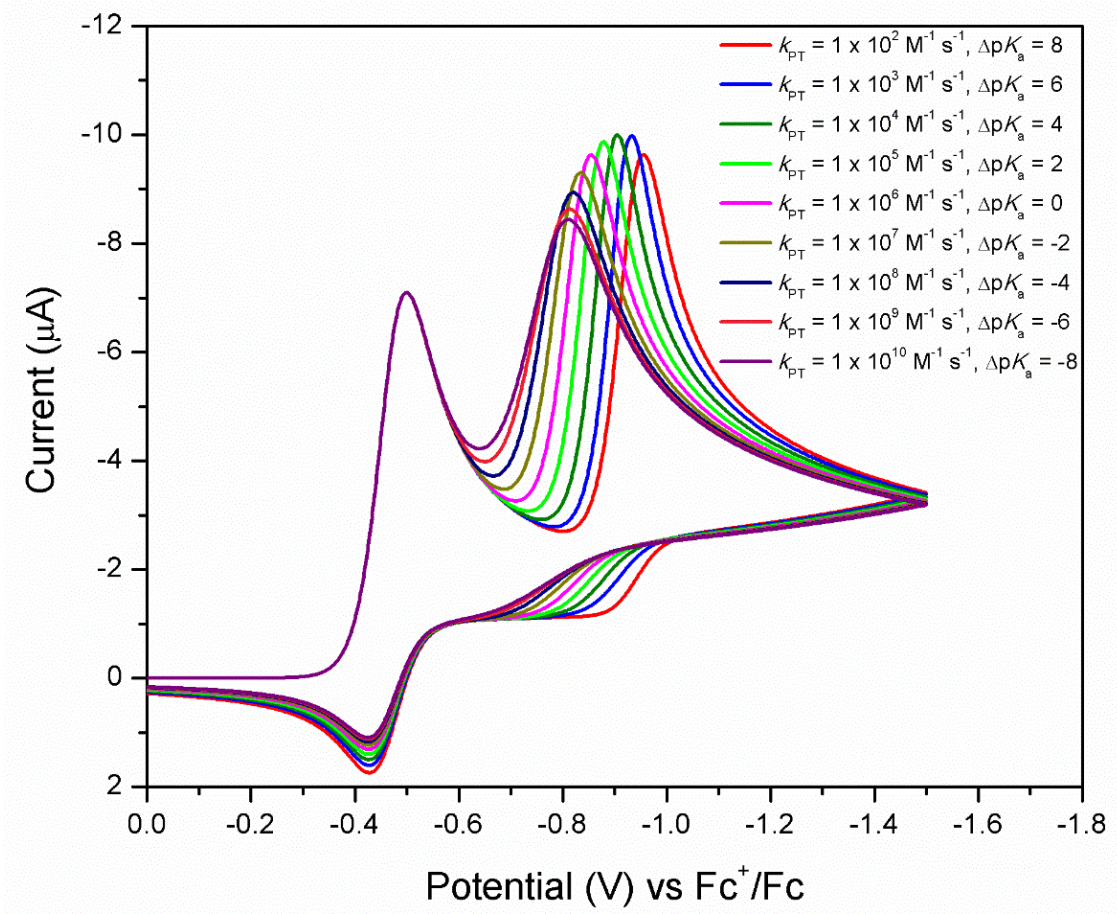

Figure S66. Simulated cyclic voltammograms $\left(v=200 \mathrm{mV} / \mathrm{s}, 0.5 \mathrm{mM} 1\right.$ in $\mathrm{CH}_{3} \mathrm{CN}, 50 \mathrm{mM}$ added acid) as a function of $k_{\mathrm{PT}}$ and $\Delta \mathrm{p} K_{\mathrm{a}}$. See Scheme $\mathrm{S} 1$. 


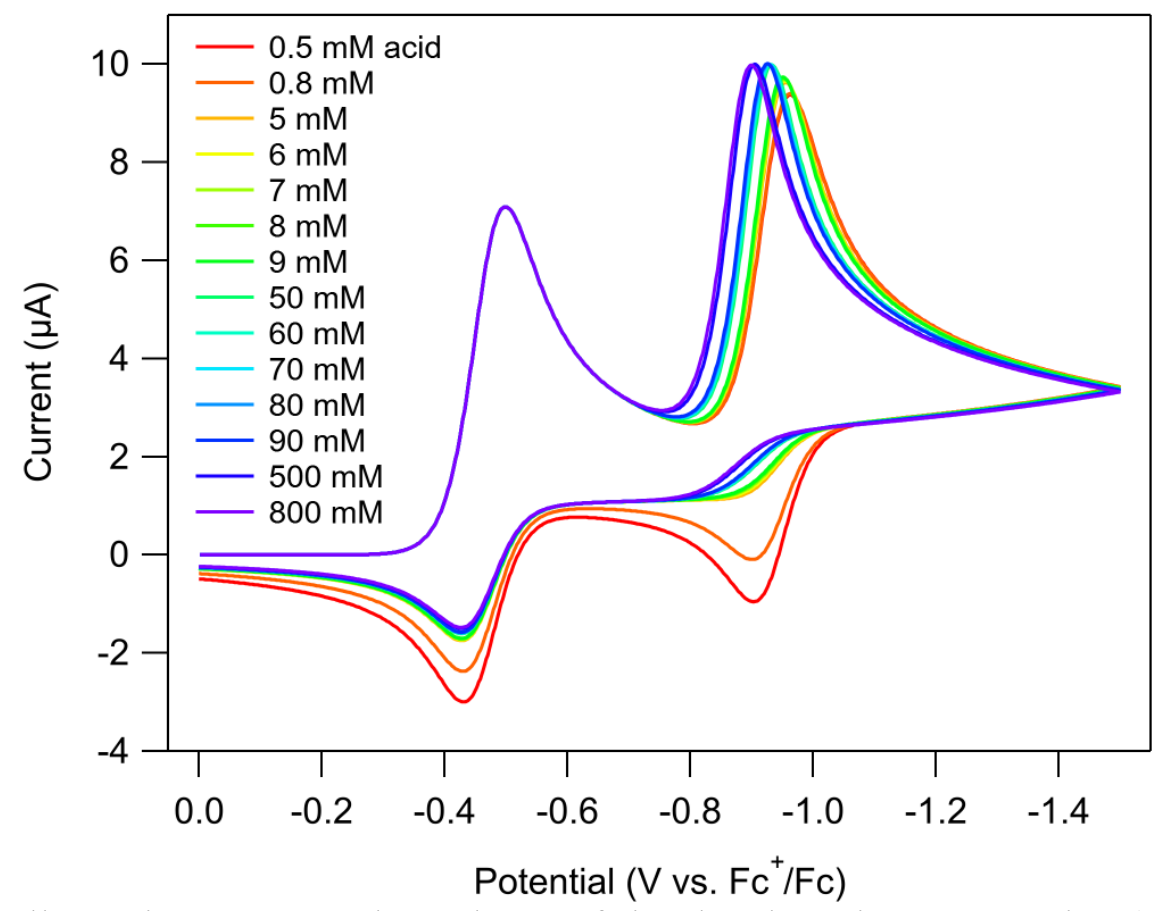

Figure S67. Illustrative scan rate dependence of simulated CV in LFER region ( $0.5 \mathrm{mM} 1$ in $\left.\mathrm{CH}_{3} \mathrm{CN}, v=200 \mathrm{mV} / \mathrm{s}\right)$.

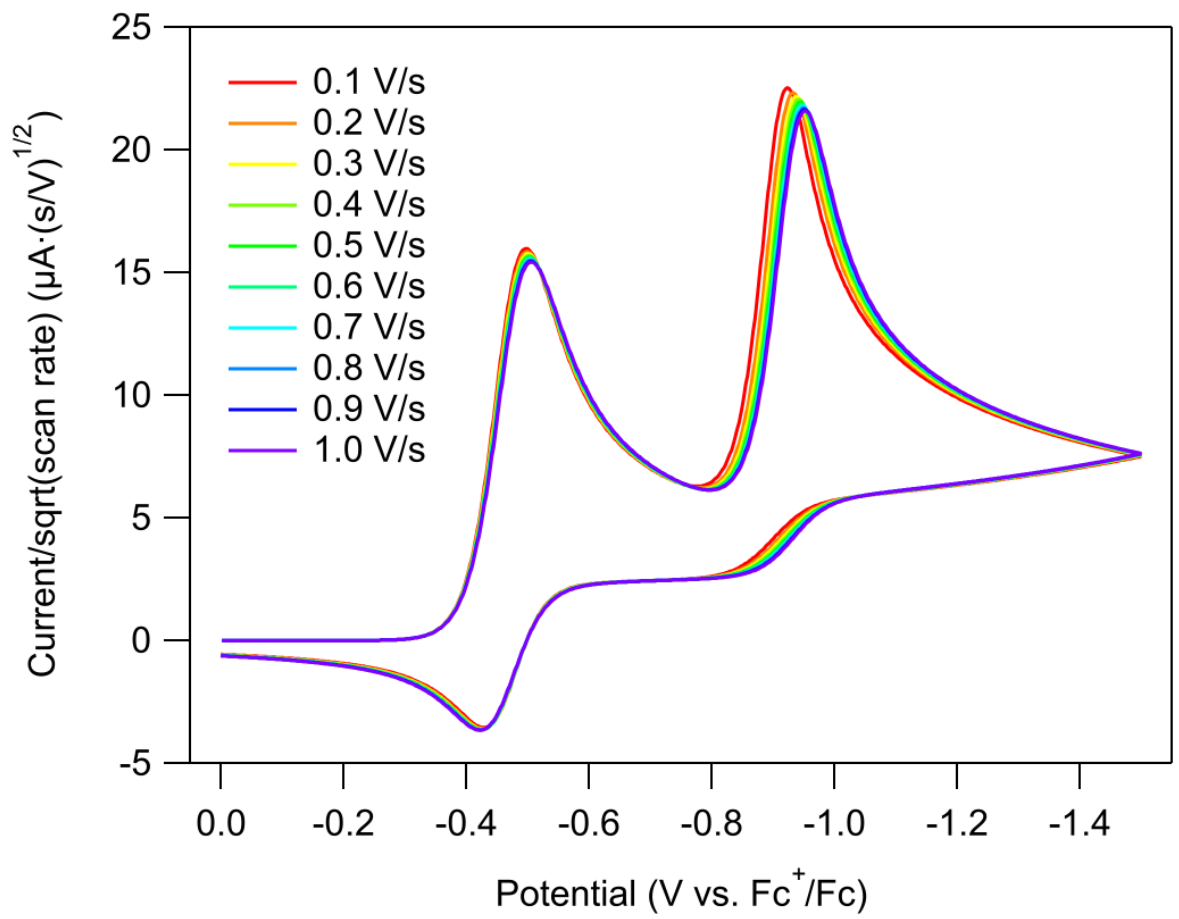

Figure S68. Illustrative acid concentration dependence of simulated CV in LFER region $(0.5$ $\mathrm{mM} 1$ in $\mathrm{CH}_{3} \mathrm{CN}, 50 \mathrm{mM}$ added). 


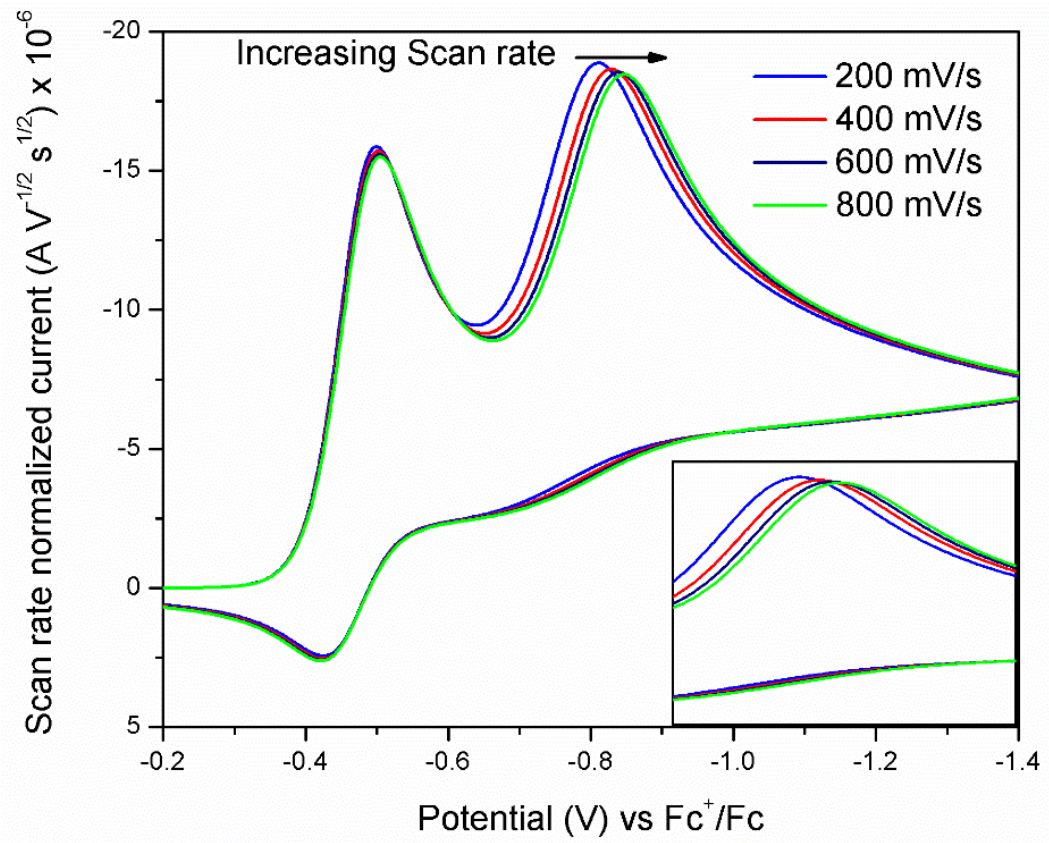

Figure S69. Simulated voltammograms illustrating the evolution of the $\mathrm{Co}(\mathrm{II} / \mathrm{I})$ peak position with scan rate $\left(v=200 \mathrm{mV} / \mathrm{s}, 0.5 \mathrm{mM} 1\right.$ in $\mathrm{CH}_{3} \mathrm{CN}, 50 \mathrm{mM}$ added acid $)$ with $k_{\mathrm{PT}}=1 \times 10^{9} \mathrm{M}^{-1} \mathrm{~s}^{-}$ ${ }^{1}$. Inset shows the $\mathrm{Co}(\mathrm{II} / \mathrm{I})$ feature.
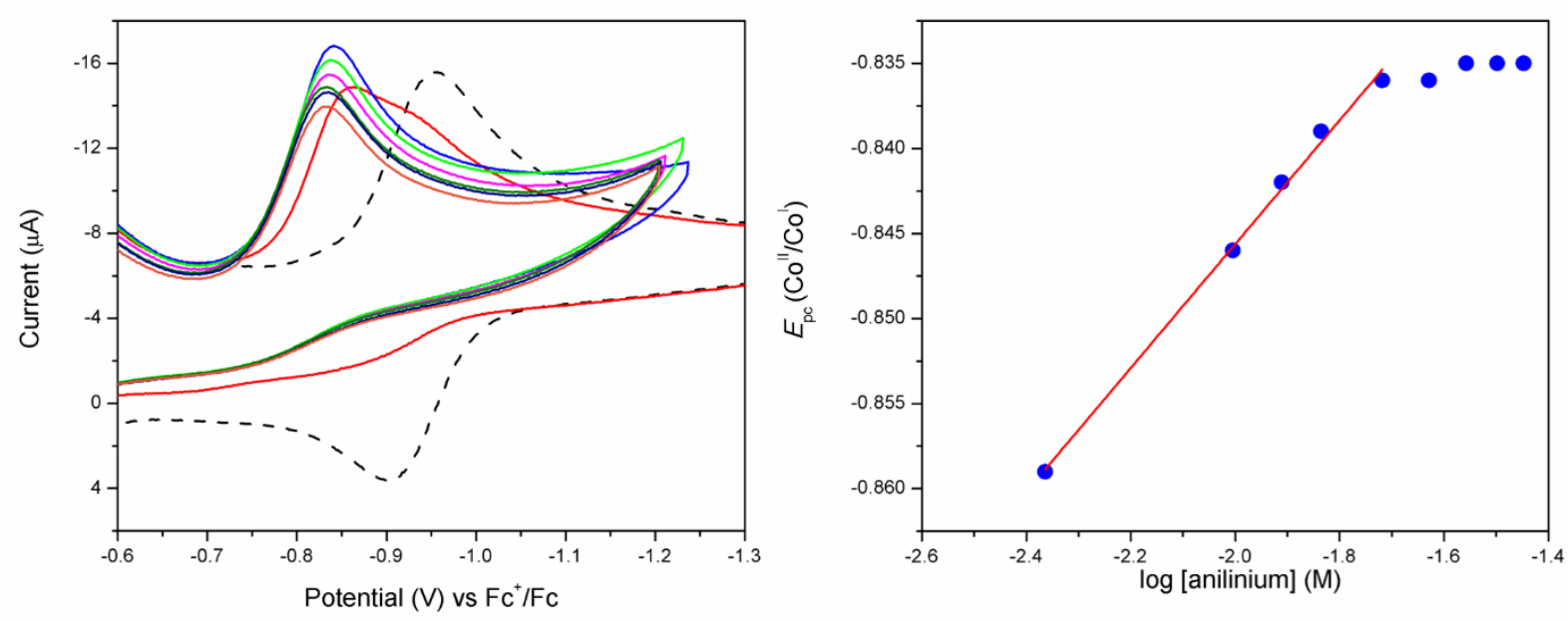

Figure S70. (Left) Experimental cyclic voltammograms illustrating the evolution of the Co(II/I) peak position with 5-40 mM anilinium $\left(v=200 \mathrm{mV} / \mathrm{s}, 0.2 \mathrm{mM} 1\right.$ with $0.25 \mathrm{M}\left[\mathrm{Bu}_{4} \mathrm{~N}\right]\left[\mathrm{PF}_{6}\right]$ in $\mathrm{CH}_{3} \mathrm{CN}$ ) (Right) Variation of $E_{\mathrm{pc}}$ with anilinium. Linear extrapolation of the free energy relationship (red line, $\mathrm{R}^{2}=0.9887$ ) has a slope of $33 \mathrm{mV} /$ decade. The peak position becomes invariant to acid concentrations when the anilinium concentration exceeds $30 \mathrm{mM}$. 
Table S5. Summary of $\boldsymbol{k}_{\boldsymbol{P T}}^{\boldsymbol{a p p}}$ for 1 utilizing different non-bulky acids with varying $\mathrm{p} K_{\mathrm{a}}$ values in DFB.

\begin{tabular}{ccc}
\hline Acid & $\begin{array}{c}\text { pKa of acid in } \\
\mathbf{C H} \mathbf{C N}\end{array}$ & $\boldsymbol{k}_{\mathbf{P T}}^{\boldsymbol{a p p}}\left(\mathbf{M}^{\mathbf{- 1}} \mathbf{s}^{\mathbf{- 1}}\right)$ \\
\hline Acetic acid & 23.51 & $2.8 \times 10^{4}$ \\
\hline 2,3,5,6-tetrafluorophenol & 20.12 & $5.1 \times 10^{5}$ \\
\hline Salicylic acid & 16.7 & $9.8 \times 10^{5}$ \\
\hline 4-CF 3 -2,3,5,6-tetrafluorophenol & 16.62 & $5.4 \times 10^{5}$ \\
\hline$p$-toluenesulfonic acid & 8.6 & $5.3 \times 10^{5}$ \\
\hline dimethylformamidium triflate & 6.1 & $8.8 \times 10^{5}$ \\
\hline
\end{tabular}

Table S6. Summary of $\boldsymbol{k}_{\boldsymbol{P T}}^{\boldsymbol{a p p}}$ for 1 utilizing different non-bulky acids with varying $\mathrm{p} K_{\mathrm{a}}$ values in $\mathrm{CH}_{2} \mathrm{Cl}_{2}$.

\begin{tabular}{ccc}
\hline Acid & $\begin{array}{c}\mathbf{p} \boldsymbol{K}_{\mathbf{a}} \text { of acid in } \\
\mathbf{C H}_{\mathbf{3}} \mathbf{C N}\end{array}$ & $\boldsymbol{k}_{\boldsymbol{P T}}^{\boldsymbol{a p p}}\left(\mathbf{M}^{-\mathbf{1}} \mathbf{s}^{-\mathbf{1}}\right)$ \\
\hline 4-CF 3 -2,3,5,6-tetrafluorophenol & 16.62 & $3.4 \times 10^{6}$ \\
\hline$p$-toluenesulfonic acid & 8.6 & $5.4 \times 10^{6}$ \\
\hline dimethylformamidium triflate & 6.1 & $2.8 \times 10^{6}$ \\
\hline
\end{tabular}

Table S7. Summary of $\boldsymbol{k}_{\boldsymbol{P T}}^{\boldsymbol{a p p}}$ of 2 utilizing different non-bulky acids with varying $\mathrm{p} K_{\mathrm{a}}$ values in DFB.

\begin{tabular}{ccc}
\hline Acid & $\begin{array}{c}\mathbf{p} \boldsymbol{K}_{\mathbf{a}} \text { of acid in } \\
\mathbf{C} \mathbf{H}_{3} \mathbf{C N}\end{array}$ & $\boldsymbol{k}_{\boldsymbol{P T}}^{\boldsymbol{a p p}}\left(\mathbf{M}^{-\mathbf{1}} \mathbf{s}^{-1}\right)$ \\
\hline 4-CF 3 -2,3,5,6-tetrafluorophenol & 16.62 & $1.3 \times 10^{6}$ \\
\hline$p$-toluenesulfonic acid & 8.6 & $2.1 \times 10^{6}$ \\
\hline dimethylformamidium triflate & 6.1 & $1.8 \times 10^{6}$ \\
\hline
\end{tabular}




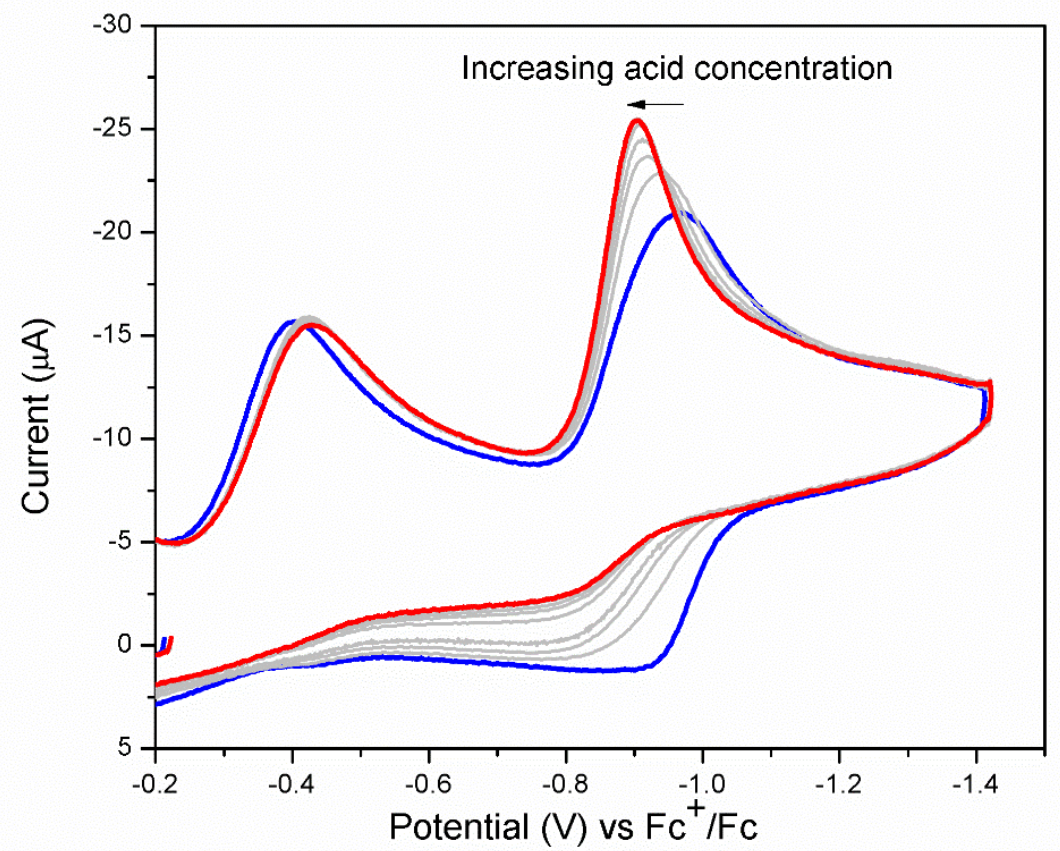

Figure S71. Experimental cyclic voltammogram of $1 \mathrm{mM} 1$ in $0.25 \mathrm{M}\left[\mathrm{Bu}_{4} \mathrm{~N}\right]\left[\mathrm{PF}_{6}\right]$ in DFB recorded at $200 \mathrm{mV} / \mathrm{s}$ in the presence of 5-50 mM 4-CF $-2,3,5,6$-tetrafluorophenol. The $E_{\mathrm{pc}}$ for the $\mathrm{Co}(\mathrm{II} / \mathrm{I})$ peak progressively depicts anodic shifts with increasing added acid at lower acid concentrations. At higher acid concentrations however, the peak position becomes insensitive to an increase in the added acid.
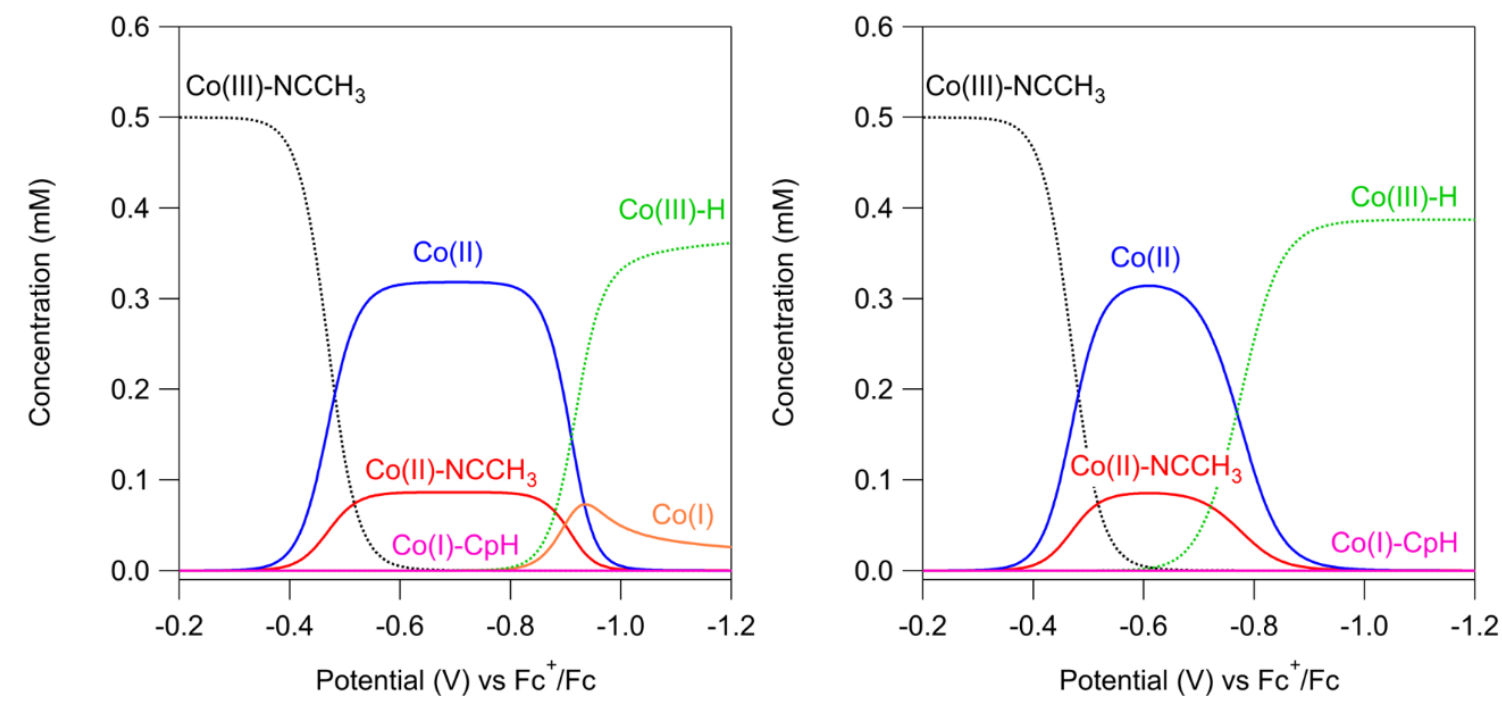

Figure S72. Surface concentration profiles as a function of the cathodic scan generated from the simulations of the voltammograms at $200 \mathrm{mV} / \mathrm{s}$ for $0.5 \mathrm{mM} 1$ in the presence of $50 \mathrm{mM}$ acid, where (left) $k_{\mathrm{PT}}=1 \times 10^{3} \mathrm{M}^{-1} \mathrm{~s}^{-1}$ (LFER region) and (right) $k_{\mathrm{PT}}=1 \times 10^{9} \mathrm{M}^{-1} \mathrm{~s}^{-1}$ (plateau region). Simulations are carried out using the reaction scheme and parameters listed in Scheme S1. In both cases, concentration of $\left[\mathrm{CoCp}(\mathrm{dppe})\left(\mathrm{NCCH}_{3}\right)\right]^{2+}$ is depicted by the dashed black trace, $\left[\mathrm{CoCp}(\mathrm{dppe})\left(\mathrm{NCCH}_{3}\right)\right]^{+}$by the red trace, $[\mathrm{CoCp}(\mathrm{dppe})]^{+}$by the blue trace, $\mathrm{CoCp}(\mathrm{dppe})$ by the orange trace and $[\mathrm{HCoCp}(\mathrm{dppe})]^{+}$by the green dashed trace. The $[\mathrm{Co}(\mathrm{CpH})(\mathrm{dppe})]^{+}$intermediate (pink trace) is in the baseline in both cases. 


\section{Surface Concentration Profiles}

Experimental and simulated voltammograms together suggest that in the plateau region, $k_{P T}^{a p p}$ does not solely reflect the elementary proton transfer step described by $k_{\text {Рт. Surface }}$ concentration profiles generated for the simulated voltammograms provide enhanced insight into the nuanced factors dictating $k_{P T}^{a p p}$. The concentration profiles detail the relative concentrations of $\left[\mathrm{CoCp}(\mathrm{dppe})\left(\mathrm{NCCH}_{3}\right)\right]^{2+}$, $\left[\mathrm{CoCp}(\mathrm{dppe})\left(\mathrm{NCCH}_{3}\right)\right]^{+}$(the ligated $\mathrm{Co}(\mathrm{II})$ species), $[\mathrm{CoCp}(\mathrm{dppe})]^{+}$ (the unligated $\mathrm{Co}(\mathrm{II})$ species), $\mathrm{CoCp}(\mathrm{dppe}),[\mathrm{Co}(\mathrm{CpH})(\mathrm{dppe})]^{+}$, and $[\mathrm{HCoCp}(\mathrm{dppe})]^{+}$as a function of the applied potential (Figure S72). Inspection of these concentration profiles reveals that for cases where $k_{\mathrm{PT}}$ is set to a value within the LFER region $\left(k_{\mathrm{PT}}=10^{3} \mathrm{M}^{-1} \mathrm{~s}^{-1}, \Delta \mathrm{p} K_{\mathrm{a}}=+6\right)$, $\mathrm{CoCp}$ (dppe) builds up at the electrode surface (at potentials lower than $-0.8 \mathrm{~V} \mathrm{vs} \mathrm{Fc}^{+/ 0}$ ) before reacting with acid to form $[\mathrm{HCoCp}(\mathrm{dppe})]^{+}$(Figure S72, left). In contrast, for cases when large proton transfer rate constants $\left(k_{\mathrm{PT}}=10^{9} \mathrm{M}^{-1} \mathrm{~s}^{-1}, \Delta \mathrm{p} K_{\mathrm{a}}=-6\right)$, there is no quantifiable $\mathrm{CoCp}(\mathrm{dppe})$ at the electrode surface as it reacts immediately with acid to form $[\mathrm{HCoCp}(\mathrm{dppe})]^{+}$.

For a simple EC reaction described by:

$$
\begin{aligned}
& {[\mathrm{CoCp}(\text { dppe })]^{+}+\mathrm{e}^{-} \rightleftharpoons \mathrm{CoCp}(\text { dppe })} \\
& \mathrm{CoCp}(\text { dppe })+\mathrm{HA} \rightarrow[\mathrm{Co}(\mathrm{Cp}-\mathrm{H})(\text { dppe })]^{+} \quad k_{P T}^{\prime}
\end{aligned}
$$

Equation 4 relates the peak shifts of $E_{\mathrm{p}, \mathrm{c}}$ to $k_{P T}^{\prime}$, [HA], and $v$. Derivation of Equation 4 is based on the relative concentrations of $[\mathrm{CoCp}(\mathrm{dppe})]^{+}$and $\mathrm{CoCp}(\mathrm{dppe})$, which evolve as a function of applied potential and are dictated by the Nernst equation. The Nernstian equilibrium between $[\mathrm{CoCp}(\mathrm{dppe})]^{+}$and $\mathrm{CoCp}(\mathrm{dppe})$ is perturbed by the chemical step succeeding reduction (protonation). Thus, when CoCp(dppe) builds up near the electrode surface, its depletion is dictated by the acid concentration and the intrinsic proton transfer rate constant (and v). As noted above, the concentration profiles determined for reactions in the LFER indeed show buildup of the $\mathrm{Co}(\mathrm{I})$ species at the electrode surface, and simulations indicate $k_{P T}^{a p p}$ values reflect the intrinsic proton transfer rate constants $\left(k_{\mathrm{PT}}\right)$. As the rate constant for the chemical step increases, Equation 4 is expected to hold for a simple EC reaction and the concentration of the 1-electron reduced intermediate is dictated by the kinetics of the $\mathrm{C}$ step. However, the concentration profiles in Figure S72 indicate that with the more complex reaction mechanism described in Scheme 4, the concentration of $\mathrm{CoCp}$ (dppe) is governed by two competing factors (1) the formation of the reactive $\mathrm{CoCp}(\mathrm{dppe})$ and (2) the consumption of $\mathrm{CoCp}(\mathrm{dppe})$ via the protonation reaction. Formation of $\mathrm{CoCp}(\mathrm{dppe})$ is directly dictated by the concentration of $[\mathrm{CoCp}(\mathrm{dppe})]^{+}$at the electrode surface, which in turn is dictated by the dissociation of $\mathrm{CH}_{3} \mathrm{CN}$ from $\left[\mathrm{CoCp}(\mathrm{dppe})\left(\mathrm{NCCH}_{3}\right)\right]^{+}$, a process described by $K_{\text {eq }}$ and $k_{\mathrm{d}}$ (see above). As such, $k_{P T}^{a p p}$ values determined for reactions with large intrinsic $k_{\mathrm{PT}}$ values (falling in the plateau region) should be dictated by the parameters that describe both ligand dissociation from $\left[\mathrm{CoCp}(\mathrm{dppe})\left(\mathrm{NCCH}_{3}\right)\right]^{+}$and protonation of $\mathrm{CoCp}(\mathrm{dppe})$. At very high $k_{\mathrm{PT}}$ values, or very high acid concentrations, the rate law would be expected to be entirely dictated by ligand dissociation, consistent with experimental observations and digital simulations. 


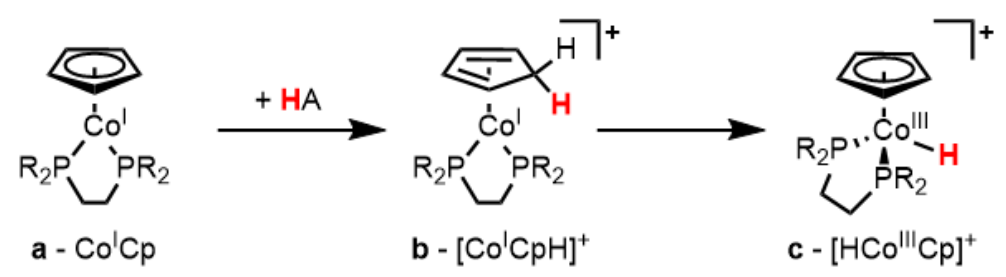

Scheme S2. Proposed $\mathrm{Cp}^{-}$protonation mechanism for hydride formation in $\mathrm{CoCp}(\mathrm{dxpe})$ systems.

Table S8. Computed free energies changes for $\mathrm{Cp}$ protonation mechanism and hydride formation in $\mathrm{CoCp}(\mathrm{dppx})$.

\begin{tabular}{cccc}
\hline Ligand & $\Delta \mathrm{G}_{a c}{ }^{i}$ & $\Delta \mathrm{G}_{a b}{ }^{i}$ & $\Delta \mathrm{G}_{b c}{ }^{i}$ \\
\hline depe & -44.3 & -23.3 & -21.0 \\
dcpe & -41.8 & -21.0 & -20.8 \\
dppe & -35.7 & -17.1 & -18.6 \\
\hline${ }^{i} \Delta G(\mathrm{kcal}$ & $\left.\mathrm{mol}^{-1}\right)$ & computed for reactions in \\
Scheme S2 $(\boldsymbol{a} \rightarrow \boldsymbol{c}, \boldsymbol{a} \rightarrow \boldsymbol{b}, \boldsymbol{b} \rightarrow \boldsymbol{c}) . \Delta G$ for $\mathrm{H}^{+}$was \\
estimated from an average of calculated acid/base \\
pairs of acetic acid/acetate and anilinium/aniline.
\end{tabular}

\section{Crystallographic Details}

\section{General Considerations}

Single-crystal X-ray diffraction data were collected on a Bruker Smart Apex-II diffractometer at $100 \pm 2 \mathrm{~K}$ with $\mathrm{Cu} \mathrm{K} \alpha$ radiation $(\lambda=1.54175 \AA)$.

Structure solution and refinement of [HCoCp (depe)][PF 6 (5)

A yellow crystal (approximate dimensions $0.400 \times 0.300 \times 0.050 \mathrm{~mm}^{3}$ ) was placed onto the tip of MiTeGen and mounted on a Bruker SMART Apex II diffractometer and measured at $293 \mathrm{~K}$. A preliminary set of cell constants was calculated from reflections harvested from three sets of 12 frames. These initial sets of frames were oriented such that orthogonal wedges of reciprocal space were surveyed. This produced initial orientation matrices determined from 88 reflections. The data collection was carried out using $\mathrm{Cu} \mathrm{K} \alpha$ radiation (graphite monochromator) with a frame time of 10 seconds and a detector distance of $4.0 \mathrm{~cm}$. A randomly oriented region of reciprocal space was surveyed to achieve complete data with a redundancy of 4 . Sections of frames were collected with $0.50^{\circ}$ steps in $\omega$ and $\phi$ scans. Data to a resolution of $0.84 \AA$ were considered in the reduction. Final cell constants were calculated from the xyz centroids of 9185 strong reflections from the actual data collection after integration (SAINT). ${ }^{4}$ The intensity data were corrected for absorption (SADABS). ${ }^{5}$ Please refer to Table 7 for additional crystal and refinement information.

The space group $\mathrm{P} 2 \mathrm{1} / \mathrm{n}$ was determined based on intensity statistics and systematic absences. The structure was solved using Superflip ${ }^{6}$ and refined (full-matrix-least squares) using the Oxford University Crystals for Windows system. ${ }^{7}$ The charge-flipping solution provided most non-hydrogen atoms from the E-map. Full-matrix least squares/difference Fourier cycles were 
performed, which located the remaining non-hydrogen atoms. All non-hydrogen atoms were refined with anisotropic displacement parameters. The hydrogen atoms were placed in ideal positions and refined with individual relative isotropic displacement parameters. The final full matrix least squares refinement converged to $\mathrm{R} 1=0.0651$ and $\mathrm{wR} 2=0.1717$ ( $\mathrm{F}^{2}$, all data).

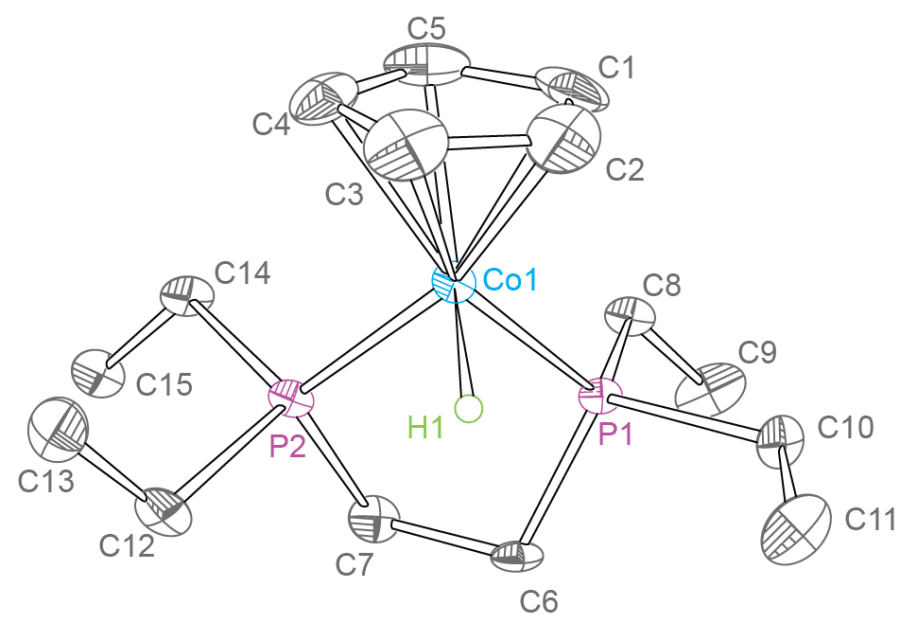

Figure S73. Crystal structure of $\left[\mathrm{HCoCp}(\right.$ depe $)\left[\mathrm{PF}_{6}\right](5)$ with thermal ellipsoids drawn at 50\% probability. Blue, gray, purple, and green atoms represent $\mathrm{Co}, \mathrm{C}, \mathrm{P}$, and $\mathrm{H}$, respectively. H-atoms other than hydride and $\mathrm{PF}_{6}{ }^{-}$omitted for clarity.

Table S9. Crystal data and structure refinement for 5 .

$\begin{array}{lll}\text { Empirical formula } & \mathrm{C} 15 \mathrm{H} 30 \mathrm{Co} 1 \mathrm{~F} 6 \mathrm{P} 3 & \\ \text { Formula weight } & 476.25 & \\ \text { Crystal color, shape, size } & \text { yellow plate fragment, } 0.400 \times 0.300 \times 0.050 \mathrm{~mm}^{3} \\ \text { Temperature } & 293 \mathrm{~K} & \\ \text { Wavelength } & 1.54178 \AA & \\ \text { Crystal system, space group } & \text { Monoclinic, P2 } 1 / \mathrm{n} & \\ \text { Unit cell dimensions } & \mathrm{a}=14.4401(2) \AA & \alpha=90^{\circ} . \\ & \mathrm{b}=10.3429(2) \AA & \beta=112.7157(9)^{\circ} . \\ & \mathrm{c}=14.6580(2) \AA & \\ \text { Volume } & 2019.40(6) \AA^{3} & \\ Z & 4 & \\ \text { Density (calculated) } & 1.566 \mathrm{Mg} / \mathrm{m}^{3} & \\ \text { Absorption coefficient } & 9.388 \mathrm{~mm}^{-1} & \\ \text { F(000) } & 984.000 & \end{array}$

Data collection 
Diffractometer

Theta range for data collection

Index ranges

Reflections collected

Independent reflections

Observed Reflections

Completeness to theta $=30.844^{\circ}$

Solution and Refinement

Absorption correction

Max. and min. transmission

Solution

Refinement method

Weighting scheme

Data / restraints / parameters

Goodness-of-fit on $\mathrm{F}^{2}$

Final $\mathrm{R}$ indices [I $>2 \operatorname{sigma}(\mathrm{I})]$

$\mathrm{R}$ indices (all data)

Largest diff. peak and hole
Bruker Apex Kappa Duo, Bruker

3.650 to $70.099^{\circ}$.

$-12<=\mathrm{h}<=17,-12<=\mathrm{k}<=12,-17<=\mathrm{l}<=17$

19425

$3743[\mathrm{R}(\mathrm{int})=0.066]$

3504

$99.0 \%$

Semi-empirical from equivalents

0.63 and 0.06

Superflip

Full-matrix least-squares on $\mathrm{F}^{2}$

$\mathrm{w}=\left[\sigma^{2} \mathrm{Fo}^{2}+\mathrm{AP}^{2}+\mathrm{BP}\right]^{-1}$, with

$\mathrm{P}=\left(\mathrm{Fo}^{2}+2 \mathrm{Fc}^{2}\right) / 3, \mathrm{~A}=0.067, \mathrm{~B}=12.780$

$3728 / 63 / 263$

1.0617

$\mathrm{R} 1=0.0651, \mathrm{wR} 2=0.1695$

$\mathrm{R} 1=0.0681, w \mathrm{R} 2=0.1717$

1.00 and -0.95 e. $\AA^{-3}$

Table S10. Crystallographic bond distances for 5 .

\begin{tabular}{lll}
\hline Atom1 & Atom2 & Length \\
\hline Co1 & P1 & $2.141(1)$ \\
Co1 & P2 & $2.150(1)$ \\
Co1 & C1 & $2.043(5)$ \\
Co1 & C2 & $2.059(7)$ \\
Co1 & C3 & $2.075(7)$ \\
Co1 & C4 & $2.074(5)$ \\
Co1 & C5 & $2.071(6)$ \\
Co1 & H1 & 1.4132 \\
P1 & C6 & $1.830(4)$ \\
P1 & C 8 & $1.827(5)$ \\
P1 & C10 & $1.822(5)$ \\
P2 & C7 & $1.842(6)$ \\
P2 & C12 & $1.820(5)$ \\
P2 & C14 & $1.830(5)$ \\
C1 & C2 & $1.38(1)$ \\
C1 & C5 & $1.44(1)$ \\
C1 & H11 & 0.951 \\
C2 & C3 & $1.36(1)$ \\
C2 & H21 & 0.95 \\
C3 & C4 & $1.40(1)$
\end{tabular}




$\begin{array}{lll}\text { C3 } & \text { H31 } & 0.95 \\ \text { C4 } & \text { C5 } & 1.41(1) \\ \text { C4 } & \text { H41 } & 0.949 \\ \text { C5 } & \text { H51 } & 0.95 \\ \text { C6 } & \text { C7 } & 1.540(8) \\ \text { C6 } & \text { H61 } & 0.949 \\ \text { C6 } & \text { H62 } & 0.95 \\ \text { C7 } & \text { H71 } & 0.95 \\ \text { C7 } & \text { H72 } & 0.949 \\ \text { C8 } & \text { C9 } & 1.512(8) \\ \text { C8 } & \text { H81 } & 0.95 \\ \text { C8 } & \text { H82 } & 0.949 \\ \text { C9 } & \text { H91 } & 0.95 \\ \text { C9 } & \text { H92 } & 0.95 \\ \text { C9 } & \text { H93 } & 0.951 \\ \text { C10 } & \text { C11 } & 1.530(8) \\ \text { C10 } & \text { H101 } & 0.949 \\ \text { C10 } & \text { H102 } & 0.951 \\ \text { C11 } & \text { H111 } & 0.949 \\ \text { C11 } & \text { H112 } & 0.95 \\ \text { C11 } & \text { H113 } & 0.949 \\ \text { C12 } & \text { C13 } & 1.513(9) \\ \text { C12 } & \text { H121 } & 0.95 \\ \text { C12 } & \text { H122 } & 0.95 \\ \text { C13 } & \text { H131 } & 0.95 \\ \text { C13 } & \text { H132 } & 0.95 \\ \text { C13 } & \text { H133 } & 0.95 \\ \text { C14 } & \text { C15 } & 1.522(8) \\ \text { C14 } & \text { H141 } & 0.949 \\ \text { C14 } & \text { H142 } & 0.95 \\ \text { C15 } & \text { H151 } & 0.95 \\ \text { C15 } & \text { H152 } & 0.95 \\ \text { C15 } & \text { H153 } & 0.95 \\ \text { P3 } & \text { F1 } & 1.59(1) \\ \text { P3 } & \text { F2 } & 1.600(3) \\ \text { P3 } & \text { F3 } & 1.60(1) \\ \text { P3 } & \text { F4 } & 1.601(3) \\ \text { P3 } & \text { F5 } & 1.589(8) \\ \text { P3 } & \text { F6 } & 1.603(6)\end{array}$

Table S11. Crystallographic bond angles for 5 .

\begin{tabular}{llll}
\hline Atom1 & Atom2 & Atom3 & Angle \\
\hline P1 & Co1 & P2 & $87.97(5)$
\end{tabular}




$\begin{array}{llll}\text { P1 } & \text { Co1 } & \text { C1 } & 96.9(2) \\ \text { P1 } & \text { Co1 } & \text { C2 } & 112.0(2) \\ \text { P1 } & \text { Co1 } & \text { C3 } & 148.8(2) \\ \text { P1 } & \text { Co1 } & \text { C4 } & 157.8(2) \\ \text { P1 } & \text { Co1 } & \text { C5 } & 118.0(2) \\ \text { P1 } & \text { Co1 } & \text { H1 } & 83.15 \\ \text { P2 } & \text { Co1 } & \text { C1 } & 147.6(2) \\ \text { P2 } & \text { Co1 } & \text { C2 } & 159.3(2) \\ \text { P2 } & \text { Co1 } & \text { C3 } & 120.9(2) \\ \text { P2 } & \text { Co1 } & \text { C4 } & 97.7(2) \\ \text { P2 } & \text { Co1 } & \text { C5 } & 109.1(2) \\ \text { P2 } & \text { Co1 } & \text { H1 } & 86.75 \\ \text { C1 } & \text { Co1 } & \text { C2 } & 39.4(3) \\ \text { C1 } & \text { Co1 } & \text { C3 } & 65.7(3) \\ \text { C1 } & \text { Co1 } & \text { C4 } & 67.1(2) \\ \text { C1 } & \text { Co1 } & \text { C5 } & 41.0(3) \\ \text { C1 } & \text { Co1 } & \text { H1 } & 125.6 \\ \text { C2 } & \text { Co1 } & \text { C3 } & 38.4(3) \\ \text { C2 } & \text { Co1 } & \text { C4 } & 66.0(3) \\ \text { C2 } & \text { Co1 } & \text { C5 } & 67.2(3) \\ \text { C2 } & \text { Co1 } & \text { H1 } & 90.1 \\ \text { C3 } & \text { Co1 } & \text { C4 } & 39.3(2) \\ \text { C3 } & \text { Co1 } & \text { C5 } & 66.5(3) \\ \text { C3 } & \text { Co1 } & \text { H1 } & 86.7 \\ \text { C4 } & \text { Co1 } & \text { C5 } & 39.9(2) \\ \text { C4 } & \text { Co1 } & \text { H1 } & 118.4 \\ \text { C5 } & \text { Co1 } & \text { H1 } & 153.1 \\ \text { Co1 } & \text { P1 } & \text { C6 } & 106.4(2) \\ \text { Co1 } & \text { P1 } & \text { C8 } & 115.4(2) \\ \text { Co1 } & \text { P1 } & \text { C10 } & 118.4(2) \\ \text { C6 } & \text { P1 } & \text { C8 } & 104.9(2) \\ \text { C6 } & \text { P1 } & \text { C10 } & 106.6(2) \\ \text { C8 } & \text { P1 } & \text { C10 } & 104.0(2) \\ \text { Co1 } & \text { P2 } & \text { C7 } & 109.3(2) \\ \text { Co1 } & \text { P2 } & \text { C12 } & 116.0(2) \\ \text { Co1 } & \text { P2 } & \text { C14 } & 115.8(2) \\ \text { C7 } & \text { P2 } & \text { C12 } & 103.4(2) \\ \text { C7 } & \text { P2 } & \text { C14 } & 105.7(2) \\ \text { P2 } & \text { C1 } 14 & 105.5(2) \\ \text { C1 } 1 & \text { H11 } & 125.6\end{array}$




\begin{tabular}{|c|c|c|c|}
\hline $\mathrm{C} 5$ & $\mathrm{C} 1$ & H11 & 126.3 \\
\hline Col & $\mathrm{C} 2$ & $\mathrm{C} 1$ & $69.7(4)$ \\
\hline Co1 & $\mathrm{C} 2$ & $\mathrm{C} 3$ & $71.4(4)$ \\
\hline Co1 & $\mathrm{C} 2$ & $\mathrm{H} 21$ & 125.3 \\
\hline $\mathrm{C} 1$ & $\mathrm{C} 2$ & $\mathrm{C} 3$ & $109.0(6)$ \\
\hline $\mathrm{C} 1$ & $\mathrm{C} 2$ & $\mathrm{H} 21$ & 125.8 \\
\hline $\mathrm{C} 3$ & $\mathrm{C} 2$ & $\mathrm{H} 21$ & 125.1 \\
\hline Col & C3 & $\mathrm{C} 2$ & $70.1(4)$ \\
\hline Co1 & C3 & $\mathrm{C} 4$ & $70.3(4)$ \\
\hline Co1 & C3 & H31 & 125.4 \\
\hline $\mathrm{C} 2$ & C3 & $\mathrm{C} 4$ & $109.4(6)$ \\
\hline $\mathrm{C} 2$ & C3 & H31 & 125.4 \\
\hline $\mathrm{C} 4$ & C3 & H31 & 125.2 \\
\hline Col & $\mathrm{C} 4$ & $\mathrm{C} 3$ & $70.4(4)$ \\
\hline Co1 & $\mathrm{C} 4$ & $\mathrm{C} 5$ & $70.0(4)$ \\
\hline Col & $\mathrm{C} 4$ & H41 & 126 \\
\hline $\mathrm{C} 3$ & $\mathrm{C} 4$ & $\mathrm{C} 5$ & $108.1(6)$ \\
\hline $\mathrm{C} 3$ & $\mathrm{C} 4$ & H41 & 126.1 \\
\hline $\mathrm{C} 5$ & $\mathrm{C} 4$ & H41 & 125.9 \\
\hline Co1 & C5 & $\mathrm{C} 1$ & $68.4(4)$ \\
\hline Co1 & $\mathrm{C} 5$ & $\mathrm{C} 4$ & $70.2(4)$ \\
\hline Co1 & C5 & H51 & 127.3 \\
\hline $\mathrm{C} 1$ & $\mathrm{C} 5$ & $\mathrm{C} 4$ & $105.6(6)$ \\
\hline $\mathrm{C} 1$ & C5 & H51 & 127.1 \\
\hline $\mathrm{C} 4$ & $\mathrm{C} 5$ & H51 & 127.3 \\
\hline P1 & C6 & $\mathrm{C} 7$ & $107.1(3)$ \\
\hline P1 & C6 & H61 & 110.1 \\
\hline P1 & C6 & H62 & 110.1 \\
\hline $\mathrm{C} 7$ & C6 & H61 & 110 \\
\hline C7 & C6 & H62 & 110 \\
\hline H61 & C6 & H62 & 109.5 \\
\hline P2 & $\mathrm{C} 7$ & C6 & $109.2(4)$ \\
\hline $\mathrm{P} 2$ & $\mathrm{C} 7$ & H71 & 109.5 \\
\hline P2 & $\mathrm{C} 7$ & $\mathrm{H} 72$ & 109.5 \\
\hline C6 & $\mathrm{C} 7$ & H71 & 109.6 \\
\hline C6 & $\mathrm{C} 7$ & $\mathrm{H} 72$ & 109.5 \\
\hline H71 & $\mathrm{C} 7$ & H72 & 109.5 \\
\hline P1 & $\mathrm{C} 8$ & C9 & $115.7(4)$ \\
\hline P1 & $\mathrm{C} 8$ & H81 & 107.9 \\
\hline P1 & $\mathrm{C} 8$ & H82 & 108 \\
\hline C9 & $\mathrm{C} 8$ & H81 & 108 \\
\hline C9 & $\mathrm{C} 8$ & H82 & 107.8 \\
\hline H81 & C8 & H82 & 109.4 \\
\hline C8 & C9 & H91 & 109.6 \\
\hline
\end{tabular}




\begin{tabular}{|c|c|c|c|}
\hline $\mathrm{C} 8$ & C9 & H92 & 109.3 \\
\hline $\mathrm{C} 8$ & C9 & H93 & 109.6 \\
\hline H91 & C9 & H92 & 109.4 \\
\hline H91 & C9 & H93 & 109.5 \\
\hline H92 & C9 & H93 & 109.4 \\
\hline P1 & $\mathrm{C} 10$ & C11 & $114.7(4)$ \\
\hline P1 & $\mathrm{C} 10$ & H101 & 108.1 \\
\hline P1 & $\mathrm{C} 10$ & H102 & 108.1 \\
\hline C11 & $\mathrm{C} 10$ & H101 & 108.2 \\
\hline C11 & $\mathrm{C} 10$ & H102 & 108.2 \\
\hline H101 & $\mathrm{C} 10$ & H102 & 109.4 \\
\hline $\mathrm{C} 10$ & C11 & H111 & 109.2 \\
\hline C10 & C11 & H112 & 109.5 \\
\hline C10 & C11 & H113 & 109.5 \\
\hline H111 & C11 & H112 & 109.5 \\
\hline H111 & C11 & H113 & 109.6 \\
\hline H112 & C11 & H113 & 109.5 \\
\hline $\mathrm{P} 2$ & $\mathrm{C} 12$ & C13 & $114.6(4)$ \\
\hline $\mathrm{P} 2$ & $\mathrm{C} 12$ & H121 & 108.2 \\
\hline P2 & $\mathrm{C} 12$ & H122 & 108.3 \\
\hline C13 & $\mathrm{C} 12$ & H121 & 108 \\
\hline C13 & $\mathrm{C} 12$ & H122 & 108.2 \\
\hline H121 & $\mathrm{C} 12$ & H122 & 109.5 \\
\hline C12 & $\mathrm{C} 13$ & H131 & 109.6 \\
\hline C12 & $\mathrm{C} 13$ & H132 & 109.6 \\
\hline C12 & $\mathrm{C} 13$ & H133 & 109.4 \\
\hline H131 & $\mathrm{C} 13$ & H132 & 109.4 \\
\hline H131 & $\mathrm{C} 13$ & H133 & 109.4 \\
\hline H132 & $\mathrm{C} 13$ & H133 & 109.5 \\
\hline $\mathrm{P} 2$ & $\mathrm{C} 14$ & C15 & $115.5(4)$ \\
\hline $\mathrm{P} 2$ & $\mathrm{C} 14$ & H141 & 107.9 \\
\hline P2 & $\mathrm{C} 14$ & H142 & 108 \\
\hline C15 & $\mathrm{C} 14$ & H141 & 108 \\
\hline C15 & $\mathrm{C} 14$ & H142 & 107.9 \\
\hline H141 & $\mathrm{C} 14$ & H142 & 109.5 \\
\hline C14 & $\mathrm{C} 15$ & H151 & 109.5 \\
\hline C14 & $\mathrm{C} 15$ & H152 & 109.3 \\
\hline C14 & $\mathrm{C} 15$ & H153 & 109.5 \\
\hline H151 & $\mathrm{C} 15$ & H152 & 109.5 \\
\hline H151 & $\mathrm{C} 15$ & H153 & 109.5 \\
\hline H152 & $\mathrm{C} 15$ & H153 & 109.5 \\
\hline $\mathrm{F} 1$ & P3 & $\mathrm{F} 2$ & $88.4(4)$ \\
\hline F1 & P3 & F3 & $175.1(6)$ \\
\hline F1 & P3 & F4 & $91.9(4)$ \\
\hline
\end{tabular}




$\begin{array}{llll}\text { F1 } & \text { P3 } & \text { F5 } & 93.0(6) \\ \text { F1 } & \text { P3 } & \text { F6 } & 87.2(6) \\ \text { F2 } & \text { P3 } & \text { F3 } & 88.8(5) \\ \text { F2 } & \text { P3 } & \text { F4 } & 179.7(2) \\ \text { F2 } & \text { P3 } & \text { F5 } & 88.9(5) \\ \text { F2 } & \text { P3 } & \text { F6 } & 86.2(5) \\ \text { F3 } & \text { P3 } & \text { F4 } & 90.9(5) \\ \text { F3 } & \text { P3 } & \text { F5 } & 91.0(7) \\ \text { F3 } & \text { P3 } & \text { F6 } & 88.6(6) \\ \text { F4 } & \text { P3 } & \text { F5 } & 90.9(5) \\ \text { F4 } & \text { P3 } & \text { F6 } & 94.0(5) \\ \text { F5 } & \text { P3 } & \text { F6 } & 175.1(6)\end{array}$

Structure solution and refinement of $[\mathrm{HCoCp}(d c p e)]\left[\mathrm{PF}_{6}\right]$ (6)

A yellow crystal (approximate dimensions $0.200 \times 0.200 \times 0.200 \mathrm{~mm}^{3}$ ) was placed onto the tip of MiTeGen and mounted on a Bruker SMART Apex II diffractometer and measured at $150 \mathrm{~K}$. A preliminary set of cell constants was calculated from reflections harvested from three sets of 12 frames. These initial sets of frames were oriented such that orthogonal wedges of reciprocal space were surveyed. This produced initial orientation matrices determined from 94 reflections. The data collection was carried out using $\mathrm{Cu} \mathrm{K} \alpha$ radiation (graphite monochromator) with a frame time of 10 seconds and a detector distance of $4.0 \mathrm{~cm}$. A randomly oriented region of reciprocal space was surveyed to achieve complete data with a redundancy of 4 . Sections of frames were collected with $0.50^{\circ}$ steps in $\omega$ and $\phi$ scans. Data to a resolution of $0.84 \AA$ were considered in the reduction. Final cell constants were calculated from the xyz centroids of 7124 strong reflections from the actual data collection after integration (SAINT). ${ }^{4}$ The intensity data were corrected for absorption (SADABS). ${ }^{5}$ Please refer to Table 8 for additional crystal and refinement information.

The space group $\mathrm{P} 21 / \mathrm{n}$ was determined based on intensity statistics and systematic absences. The structure was solved using Superflip ${ }^{6}$ and refined (full-matrix-least squares) using the Oxford University Crystals for Windows system. ${ }^{7}$ The charge-flipping solution provided most non-hydrogen atoms from the E-map. Full-matrix least squares/difference Fourier cycles were performed, which located the remaining non-hydrogen atoms.

This structure exhibits significant disorder on the $\mathrm{PF}_{6}{ }^{-}$, which was modeled successfully. The 2-part disorder was modeled that the major and minor components summed to 1 . All nonhydrogen atoms were refined with anisotropic displacement parameters. The hydride was obtained from Fourier difference map and its position was refined. The rest of the hydrogen atoms were placed in ideal positions and refined as riding atoms. The final full matrix least squares refinement converged to $\mathrm{R} 1=0.0539$ and $\mathrm{wR} 2=0.1220\left(\mathrm{~F}^{2}\right.$, all data $)$. 


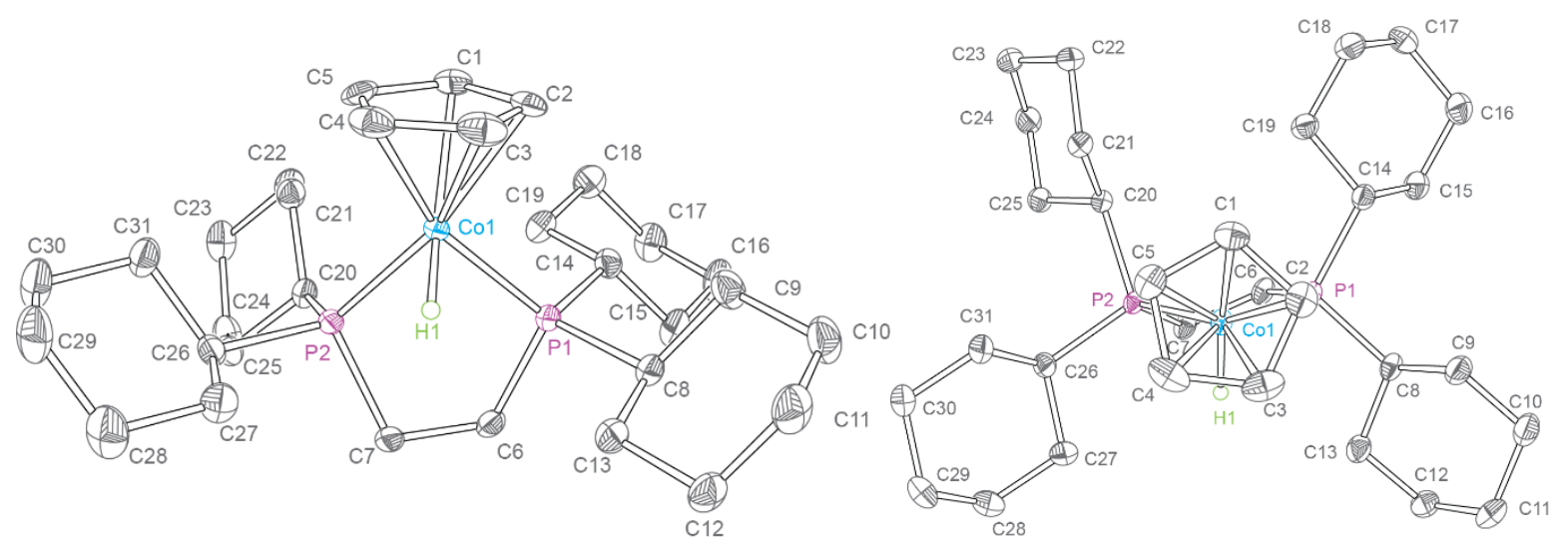

Figure S74. Crystal structure of $[\mathrm{HCoCp}(\mathrm{dcpe})]\left[\mathrm{PF}_{6}\right](6)$ from two different angles with thermal ellipsoids drawn at $50 \%$ probability. Blue, gray, purple, and green atoms represent $\mathrm{Co}, \mathrm{C}, \mathrm{P}$, and $\mathrm{H}$, respectively. $\mathrm{H}$-atoms other than hydride and $\mathrm{PF}_{6}{ }^{-}$omitted for clarity.

Table S12. Crystal data and structure refinement for $\mathbf{6}$.

Empirical formula

Formula weight

Crystal color, shape, size

Temperature

Wavelength

Crystal system, space group

Unit cell dimensions

Volume

Z

Density (calculated)

Absorption coefficient

$\mathrm{F}(000)$

Data collection

Diffractometer

Theta range for data collection

Index ranges

Reflections collected

Independent reflections

Observed Reflections

Completeness to theta $=34.649^{\circ}$

Solution and Refinement

Absorption correction

Max. and min. transmission

Solution
C31 H54 Co1 F6 P3

692.61

yellow block fragment, $0.200 \times 0.200 \times 0.200 \mathrm{~mm}^{3}$

$150 \mathrm{~K}$

$1.54178 \AA$

Monoclinic, $\mathrm{P} 21 / \mathrm{n}$

$\mathrm{a}=13.4770(3) \AA \quad \alpha=90^{\circ}$.

$\mathrm{b}=13.0736(3) \AA$

$\beta=103.0332(13)^{\circ}$.

$\mathrm{c}=18.9767(4) \AA$ $\gamma=90^{\circ}$.

3257.43(13) $\AA^{3}$

4

$1.412 \mathrm{Mg} / \mathrm{m}^{3}$

$5.999 \mathrm{~mm}^{-1}$

1464

Bruker Apex Kappa Duo, Bruker

3.663 to $66.633^{\circ}$.

$-15<=\mathrm{h}<=13,-15<=\mathrm{k}<=15,-18<=\mathrm{l}<=22$

35113

$5679[\mathrm{R}(\mathrm{int})=0.049]$

5198

$99.5 \%$

Semi-empirical from equivalents

0.30 and 0.30

Direct methods 
Refinement method

Weighting scheme

Data / restraints / parameters Goodness-of-fit on $\mathrm{F}^{2}$

Final $\mathrm{R}$ indices [I $>2 \operatorname{sigma}(\mathrm{I})]$

$\mathrm{R}$ indices (all data)

Largest diff. peak and hole
Full-matrix least-squares on $\mathrm{F}^{2}$

$\mathrm{w}=\left[\sigma^{2} \mathrm{Fo}^{2}+\mathrm{AP}^{2}+\mathrm{BP}\right]^{-1}$, with

$\mathrm{P}=\left(\mathrm{Fo}^{2}+2 \mathrm{Fc}^{2}\right) / 3, \mathrm{~A}=0.027, \mathrm{~B}=12.300$

$5652 / 98 / 437$

1.0803

$\mathrm{R} 1=0.0539, \mathrm{wR} 2=0.1197$

$\mathrm{R} 1=0.0586, \mathrm{wR} 2=0.1220$

1.09 and -0.66 e. $\AA^{-3}$

Table S13. Crystallographic bond distances for 6 .

\begin{tabular}{lll}
\hline Atom1 & Atom2 & Length \\
\hline Co1 & P1 & $2.167(1)$ \\
Co1 & P2 & $2.1567(9)$ \\
Co1 & C1 & $2.105(4)$ \\
Co1 & C2 & $2.078(4)$ \\
Co1 & C3 & $2.065(4)$ \\
Co1 & C4 & $2.065(4)$ \\
Co1 & C5 & $2.092(4)$ \\
Co1 & H1 & $1.35(5)$ \\
P1 & C6 & $1.851(4)$ \\
P1 & C8 & $1.850(4)$ \\
P1 & C14 & $1.847(4)$ \\
P2 & C7 & $1.837(3)$ \\
P2 & C20 & $1.854(3)$ \\
P2 & C26 & $1.841(4)$ \\
C1 & C2 & $1.418(5)$ \\
C1 & C5 & $1.409(6)$ \\
C1 & H11 & 0.95 \\
C2 & C3 & $1.414(5)$ \\
C2 & H21 & 0.949 \\
C3 & C4 & $1.418(6)$ \\
C3 & H31 & 0.95 \\
C4 & C5 & $1.416(5)$ \\
C4 & H41 & 0.951 \\
C5 & H51 & 0.95 \\
C6 & C7 & $1.530(6)$ \\
C6 & H61 & 0.951 \\
C6 & H62 & 0.95 \\
C7 & H71 & 0.95 \\
C7 & H72 & 0.951 \\
C8 & C9 & $1.535(6)$ \\
C8 & C13 & $1.532(5)$ \\
C8 & H81 & 0.95 \\
C9 & C10 & $1.531(5)$ \\
& &
\end{tabular}




\begin{tabular}{|c|c|c|}
\hline C9 & H91 & 0.949 \\
\hline C9 & H92 & 0.951 \\
\hline $\mathrm{C} 10$ & C11 & $1.532(5)$ \\
\hline $\mathrm{C} 10$ & H101 & 0.949 \\
\hline $\mathrm{C} 10$ & H102 & 0.95 \\
\hline C11 & C12 & $1.516(6)$ \\
\hline C11 & H111 & 0.95 \\
\hline C11 & H1 12 & 0.95 \\
\hline C12 & C13 & $1.536(5)$ \\
\hline C12 & H121 & 0.95 \\
\hline $\mathrm{C} 12$ & H122 & 0.95 \\
\hline C13 & H131 & 0.95 \\
\hline C13 & H132 & 0.95 \\
\hline C14 & C15 & $1.534(6)$ \\
\hline C14 & C19 & $1.539(5)$ \\
\hline C14 & H141 & 0.95 \\
\hline C15 & C16 & $1.519(5)$ \\
\hline $\mathrm{C} 15$ & H151 & 0.95 \\
\hline C15 & H152 & 0.951 \\
\hline C16 & C17 & $1.530(5)$ \\
\hline $\mathrm{C} 16$ & H161 & 0.95 \\
\hline C16 & H162 & 0.951 \\
\hline $\mathrm{C} 17$ & C18 & $1.515(6)$ \\
\hline $\mathrm{C} 17$ & H171 & 0.95 \\
\hline $\mathrm{C} 17$ & H172 & 0.95 \\
\hline C18 & C19 & $1.526(5)$ \\
\hline C18 & H181 & 0.95 \\
\hline C18 & H182 & 0.951 \\
\hline C19 & H191 & 0.95 \\
\hline C19 & H192 & 0.949 \\
\hline $\mathrm{C} 20$ & C21 & $1.525(5)$ \\
\hline $\mathrm{C} 20$ & $\mathrm{C} 25$ & $1.536(5)$ \\
\hline $\mathrm{C} 20$ & H201 & 0.951 \\
\hline $\mathrm{C} 21$ & C22 & $1.534(5)$ \\
\hline $\mathrm{C} 21$ & H211 & 0.95 \\
\hline $\mathrm{C} 21$ & H212 & 0.95 \\
\hline $\mathrm{C} 22$ & C23 & $1.518(5)$ \\
\hline $\mathrm{C} 22$ & $\mathrm{H} 221$ & 0.949 \\
\hline $\mathrm{C} 22$ & $\mathrm{H} 222$ & 0.95 \\
\hline $\mathrm{C} 23$ & C24 & $1.521(5)$ \\
\hline $\mathrm{C} 23$ & H231 & 0.951 \\
\hline $\mathrm{C} 23$ & $\mathrm{H} 232$ & 0.95 \\
\hline $\mathrm{C} 24$ & $\mathrm{C} 25$ & $1.530(5)$ \\
\hline C24 & H241 & 0.95 \\
\hline
\end{tabular}




$\begin{array}{lll}\text { C24 } & \text { H242 } & 0.95 \\ \text { C25 } & \text { H251 } & 0.951 \\ \text { C25 } & \text { H252 } & 0.95 \\ \text { C26 } & \text { C27 } & 1.528(5) \\ \text { C26 } & \text { C31 } & 1.538(6) \\ \text { C26 } & \text { H261 } & 0.951 \\ \text { C27 } & \text { C28 } & 1.533(6) \\ \text { C27 } & \text { H271 } & 0.951 \\ \text { C27 } & \text { H272 } & 0.949 \\ \text { C28 } & \text { C29 } & 1.512(6) \\ \text { C28 } & \text { H281 } & 0.95 \\ \text { C28 } & \text { H282 } & 0.95 \\ \text { C29 } & \text { C30 } & 1.524(5) \\ \text { C29 } & \text { H291 } & 0.95 \\ \text { C29 } & \text { H292 } & 0.95 \\ \text { C30 } & \text { C31 } & 1.525(6) \\ \text { C30 } & \text { H301 } & 0.95 \\ \text { C30 } & \text { H302 } & 0.949 \\ \text { C31 } & \text { H311 } & 0.95 \\ \text { C31 } & \text { H312 } & 0.951 \\ \text { P3 } & \text { F1 } & 1.603(9) \\ \text { P3 } & \text { F2 } & 1.601(8) \\ \text { P3 } & \text { F3 } & 1.612(5) \\ \text { P3 } & \text { F4 } & 1.60(1) \\ \text { P3 } & \text { F5 } & 1.603(7) \\ \text { P3 } & \text { F6 } & 1.592(7)\end{array}$

Table S14. Crystallographic bond angles for 6.

\begin{tabular}{llll}
\hline Atom1 & Atom2 & Atom3 & Angle \\
\hline P1 & Co1 & P2 & $88.43(4)$ \\
P1 & Co1 & C1 & $110.2(1)$ \\
P1 & Co1 & C2 & $95.6(1)$ \\
P1 & Co1 & C3 & $116.9(1)$ \\
P1 & Co1 & C4 & $157.0(1)$ \\
P1 & Co1 & C5 & $147.7(1)$ \\
P1 & Co1 & H1 & $81(2)$ \\
P2 & Co1 & C1 & $121.1(1)$ \\
P2 & Co1 & C2 & $160.3(1)$ \\
P2 & Co1 & C3 & $150.3(1)$ \\
P2 & Co1 & C4 & $113.1(1)$ \\
P2 & Co1 & C5 & $100.4(1)$ \\
P2 & Co1 & H1 & $76(2)$ \\
C1 & Co1 & C2 & $39.6(2)$
\end{tabular}




\begin{tabular}{|c|c|c|c|}
\hline $\mathrm{C} 1$ & Col & C3 & $66.7(2)$ \\
\hline $\mathrm{C} 1$ & Col & $\mathrm{C} 4$ & $66.5(2)$ \\
\hline $\mathrm{C} 1$ & Col & C5 & $39.2(2)$ \\
\hline $\mathrm{C} 1$ & Col & $\mathrm{H} 1$ & $158(2)$ \\
\hline $\mathrm{C} 2$ & Col & C3 & $39.9(2)$ \\
\hline $\mathrm{C} 2$ & Col & $\mathrm{C} 4$ & $67.0(2)$ \\
\hline $\mathrm{C} 2$ & Col & $\mathrm{C} 5$ & $66.6(2)$ \\
\hline $\mathrm{C} 2$ & Col & H1 & $124(2)$ \\
\hline C3 & Col & $\mathrm{C} 4$ & $40.2(2)$ \\
\hline $\mathrm{C} 3$ & Col & $\mathrm{C} 5$ & $67.0(2)$ \\
\hline C3 & Col & H1 & $92(2)$ \\
\hline $\mathrm{C} 4$ & Col & $\mathrm{C} 5$ & $39.8(2)$ \\
\hline $\mathrm{C} 4$ & Col & H1 & $96(2)$ \\
\hline $\mathrm{C} 5$ & Col & H1 & $131(2)$ \\
\hline Co1 & $\mathrm{P} 1$ & C6 & $108.9(1)$ \\
\hline Col & $\mathrm{P} 1$ & $\mathrm{C} 8$ & $116.2(1)$ \\
\hline Co1 & $\mathrm{P} 1$ & $\mathrm{C} 14$ & $116.9(1)$ \\
\hline C6 & $\mathrm{P} 1$ & $\mathrm{C} 8$ & $104.1(2)$ \\
\hline C6 & $\mathrm{P} 1$ & $\mathrm{C} 14$ & $104.7(2)$ \\
\hline $\mathrm{C} 8$ & $\mathrm{P} 1$ & C14 & $104.8(2)$ \\
\hline Co1 & $\mathrm{P} 2$ & $\mathrm{C} 7$ & $105.4(1)$ \\
\hline Co1 & $\mathrm{P} 2$ & $\mathrm{C} 20$ & $117.9(1)$ \\
\hline Co1 & $\mathrm{P} 2$ & $\mathrm{C} 26$ & $118.4(1)$ \\
\hline $\mathrm{C} 7$ & $\mathrm{P} 2$ & $\mathrm{C} 20$ & $101.8(2)$ \\
\hline $\mathrm{C} 7$ & $\mathrm{P} 2$ & $\mathrm{C} 26$ & $104.2(2)$ \\
\hline $\mathrm{C} 20$ & $\mathrm{P} 2$ & $\mathrm{C} 26$ & $106.8(2)$ \\
\hline Co1 & $\mathrm{C} 1$ & $\mathrm{C} 2$ & $69.2(2)$ \\
\hline Co1 & $\mathrm{C} 1$ & $\mathrm{C} 5$ & $69.9(2)$ \\
\hline Col & $\mathrm{C} 1$ & H11 & 126.1 \\
\hline $\mathrm{C} 2$ & $\mathrm{C} 1$ & $\mathrm{C} 5$ & $108.1(3)$ \\
\hline $\mathrm{C} 2$ & $\mathrm{C} 1$ & H11 & 126 \\
\hline $\mathrm{C} 5$ & $\mathrm{C} 1$ & H11 & 125.9 \\
\hline Co1 & $\mathrm{C} 2$ & $\mathrm{C} 1$ & $71.2(2)$ \\
\hline Co1 & $\mathrm{C} 2$ & $\mathrm{C} 3$ & $69.5(2)$ \\
\hline Co1 & $\mathrm{C} 2$ & $\mathrm{H} 21$ & 125.9 \\
\hline $\mathrm{C} 1$ & $\mathrm{C} 2$ & $\mathrm{C} 3$ & $108.1(3)$ \\
\hline $\mathrm{C} 1$ & $\mathrm{C} 2$ & $\mathrm{H} 21$ & 126 \\
\hline $\mathrm{C} 3$ & $\mathrm{C} 2$ & $\mathrm{H} 21$ & 125.9 \\
\hline Col & C3 & $\mathrm{C} 2$ & $70.5(2)$ \\
\hline Co1 & $\mathrm{C} 3$ & $\mathrm{C} 4$ & $69.9(2)$ \\
\hline Co1 & C3 & H31 & 126.1 \\
\hline $\mathrm{C} 2$ & $\mathrm{C} 3$ & $\mathrm{C} 4$ & $107.7(3)$ \\
\hline $\mathrm{C} 2$ & C3 & H31 & 126 \\
\hline C4 & C3 & H31 & 126.3 \\
\hline
\end{tabular}




$\begin{array}{llll}\text { Co1 } & \text { C4 } & \text { C3 } & 69.9(2) \\ \text { Co1 } & \text { C4 } & \text { C5 } & 71.1(2) \\ \text { Co1 } & \text { C4 } & \text { H41 } & 126 \\ \text { C3 } & \text { C4 } & \text { C5 } & 108.2(3) \\ \text { C3 } & \text { C4 } & \text { H41 } & 125.9 \\ \text { C5 } & \text { C4 } & \text { H41 } & 125.9 \\ \text { Co1 } & \text { C5 } & \text { C1 } & 70.9(2) \\ \text { Co1 } & \text { C5 } & \text { C4 } & 69.0(2) \\ \text { Co1 } & \text { C5 } & \text { H51 } & 125.9 \\ \text { C1 } & \text { C5 } & \text { C4 } & 108.0(3) \\ \text { C1 } & \text { C5 } & \text { H51 } & 125.9 \\ \text { C4 } & \text { C5 } & \text { H51 } & 126.1 \\ \text { P1 } & \text { C6 } & \text { C7 } & 110.7(3) \\ \text { P1 } & \text { C6 } & \text { H61 } & 109.2 \\ \text { P1 } & \text { C6 } & \text { H62 } & 109.1 \\ \text { C7 } & \text { C6 } & \text { H61 } & 109.2 \\ \text { C7 } & \text { C6 } & \text { H62 } & 109.2 \\ \text { H61 } & \text { C6 } & \text { H62 } & 109.5 \\ \text { P2 } & \text { C7 } & \text { C6 } & 109.7(2) \\ \text { P2 } & \text { C7 } & \text { H71 } & 109.4 \\ \text { P2 } & \text { C7 } & \text { H72 } & 109.4 \\ \text { C6 } & \text { C7 } & \text { H71 } & 109.5 \\ \text { C6 } & \text { C7 } & \text { H72 } & 109.5 \\ \text { H71 } & \text { C7 } & \text { H72 } & 109.4 \\ \text { P1 } & \text { C8 } & \text { C9 } & 113.3(3) \\ \text { P1 } & \text { C8 } & \text { C13 } & 112.3(3) \\ \text { P1 } & \text { C8 } & \text { H81 } & 106.6 \\ \text { C9 } & \text { C8 } & \text { C13 } & 110.7(3) \\ \text { C9 } & \text { C8 } & \text { H81 } & 106.6 \\ \text { C13 } & \text { C8 } & \text { H81 } & 106.8 \\ \text { C8 } & \text { C9 } & \text { C10 } & 110.7(3) \\ \text { C8 } & \text { C9 } & \text { H91 } & 109.3 \\ \text { C8 } & \text { C9 } & \text { H92 } & 109.2 \\ \text { C10 } & \text { C9 } & \text { H91 } & 109.1 \\ \text { C10 } & \text { C9 } & \text { H92 } & 109.1 \\ \text { H91 } & \text { C9 } & \text { H92 } & 109.5 \\ \text { C9 } & \text { C10 } & \text { C11 } & 111.2(3) \\ \text { C9 } & \text { C10 } & \text { H101 } & 108.9 \\ \text { C9 } & \text { C10 } & \text { H102 } & 109.1 \\ \text { C11 } & \text { C10 } & \text { H101 } & 108.9 \\ \text { C11 } & \text { C10 } & \text { H102 } & 109.1 \\ \text { H102 } & 109.5 \\ \text { H12 } & 110.9(3) \\ \text { C10 } 51 & 109.1\end{array}$




\begin{tabular}{|c|c|c|c|}
\hline $\mathrm{C} 10$ & $\mathrm{C} 11$ & H112 & 109 \\
\hline C12 & C11 & H111 & 109.2 \\
\hline C12 & $\mathrm{C} 11$ & H112 & 109.1 \\
\hline H111 & $\mathrm{C} 11$ & H112 & 109.5 \\
\hline C11 & $\mathrm{C} 12$ & C13 & 111.1(3) \\
\hline C11 & $\mathrm{C} 12$ & H121 & 109.1 \\
\hline C11 & C12 & H122 & 109 \\
\hline C13 & $\mathrm{C} 12$ & H121 & 109 \\
\hline C13 & $\mathrm{C} 12$ & H122 & 109.1 \\
\hline H121 & $\mathrm{C} 12$ & H122 & 109.5 \\
\hline $\mathrm{C} 8$ & $\mathrm{C} 13$ & C12 & $110.5(3)$ \\
\hline $\mathrm{C} 8$ & $\mathrm{C} 13$ & H131 & 109.2 \\
\hline $\mathrm{C} 8$ & C13 & H132 & 109.3 \\
\hline C12 & C13 & H131 & 109.3 \\
\hline C12 & C13 & H132 & 109.1 \\
\hline H131 & C13 & H132 & 109.4 \\
\hline P1 & $\mathrm{C} 14$ & C15 & $113.5(3)$ \\
\hline $\mathrm{P} 1$ & $\mathrm{C} 14$ & C19 & $112.2(3)$ \\
\hline P1 & $\mathrm{C} 14$ & H141 & 107.1 \\
\hline C15 & C14 & C19 & $109.6(3)$ \\
\hline C15 & $\mathrm{C} 14$ & H141 & 107 \\
\hline C19 & C14 & H141 & 107.1 \\
\hline $\mathrm{C} 14$ & $\mathrm{C} 15$ & C16 & $111.3(3)$ \\
\hline C14 & C15 & H151 & 108.8 \\
\hline $\mathrm{C} 14$ & $\mathrm{C} 15$ & H152 & 109.1 \\
\hline C16 & C15 & H151 & 109.1 \\
\hline C16 & $\mathrm{C} 15$ & H152 & 109 \\
\hline H151 & $\mathrm{C} 15$ & H152 & 109.4 \\
\hline C15 & $\mathrm{C} 16$ & C17 & $112.0(3)$ \\
\hline C15 & $\mathrm{C} 16$ & H161 & 108.9 \\
\hline C15 & $\mathrm{C} 16$ & H162 & 108.8 \\
\hline $\mathrm{C} 17$ & $\mathrm{C} 16$ & H161 & 108.9 \\
\hline C17 & $\mathrm{C} 16$ & H162 & 108.8 \\
\hline H161 & $\mathrm{C} 16$ & H162 & 109.4 \\
\hline C16 & $\mathrm{C} 17$ & C18 & $110.8(3)$ \\
\hline $\mathrm{C} 16$ & $\mathrm{C} 17$ & H171 & 109.3 \\
\hline C16 & $\mathrm{C} 17$ & H172 & 109.1 \\
\hline C18 & $\mathrm{C} 17$ & H171 & 109.2 \\
\hline C18 & $\mathrm{C} 17$ & H172 & 109.1 \\
\hline H171 & $\mathrm{C} 17$ & H172 & 109.4 \\
\hline C17 & C18 & C19 & $110.7(3)$ \\
\hline C17 & $\mathrm{C} 18$ & H181 & 109.2 \\
\hline C17 & C18 & H182 & 109.2 \\
\hline C19 & C18 & H181 & 109.1 \\
\hline
\end{tabular}




\begin{tabular}{|c|c|c|c|}
\hline C19 & C18 & H182 & 109.1 \\
\hline H181 & C18 & H182 & 109.4 \\
\hline C14 & C19 & C18 & $110.7(3)$ \\
\hline $\mathrm{C} 14$ & C19 & H191 & 109.1 \\
\hline C14 & C19 & H192 & 109.1 \\
\hline C18 & C19 & H191 & 109.2 \\
\hline $\mathrm{C} 18$ & C19 & H192 & 109.3 \\
\hline H191 & C19 & H192 & 109.5 \\
\hline P2 & $\mathrm{C} 20$ & C21 & $116.1(3)$ \\
\hline P2 & $\mathrm{C} 20$ & $\mathrm{C} 25$ & $113.5(3)$ \\
\hline P2 & $\mathrm{C} 20$ & H201 & 105.2 \\
\hline $\mathrm{C} 21$ & $\mathrm{C} 20$ & $\mathrm{C} 25$ & $110.8(3)$ \\
\hline $\mathrm{C} 21$ & $\mathrm{C} 20$ & H201 & 105.1 \\
\hline $\mathrm{C} 25$ & $\mathrm{C} 20$ & H201 & 105 \\
\hline $\mathrm{C} 20$ & $\mathrm{C} 21$ & C22 & $110.1(3)$ \\
\hline $\mathrm{C} 20$ & $\mathrm{C} 21$ & H211 & 109.3 \\
\hline $\mathrm{C} 20$ & $\mathrm{C} 21$ & $\mathrm{H} 212$ & 109.4 \\
\hline $\mathrm{C} 22$ & $\mathrm{C} 21$ & H211 & 109.3 \\
\hline $\mathrm{C} 22$ & $\mathrm{C} 21$ & H212 & 109.2 \\
\hline H211 & $\mathrm{C} 21$ & $\mathrm{H} 212$ & 109.5 \\
\hline C21 & $\mathrm{C} 22$ & $\mathrm{C} 23$ & $110.9(3)$ \\
\hline C21 & $\mathrm{C} 22$ & H221 & 109.2 \\
\hline $\mathrm{C} 21$ & $\mathrm{C} 22$ & H222 & 109.1 \\
\hline $\mathrm{C} 23$ & $\mathrm{C} 22$ & H221 & 109.2 \\
\hline $\mathrm{C} 23$ & $\mathrm{C} 22$ & $\mathrm{H} 222$ & 109.1 \\
\hline H221 & $\mathrm{C} 22$ & H222 & 109.4 \\
\hline C22 & $\mathrm{C} 23$ & C24 & $112.9(3)$ \\
\hline $\mathrm{C} 22$ & $\mathrm{C} 23$ & H231 & 108.5 \\
\hline $\mathrm{C} 22$ & $\mathrm{C} 23$ & H232 & 108.6 \\
\hline C24 & $\mathrm{C} 23$ & H231 & 108.6 \\
\hline $\mathrm{C} 24$ & $\mathrm{C} 23$ & $\mathrm{H} 232$ & 108.6 \\
\hline H231 & $\mathrm{C} 23$ & $\mathrm{H} 232$ & 109.5 \\
\hline $\mathrm{C} 23$ & $\mathrm{C} 24$ & $\mathrm{C} 25$ & 112.1(3) \\
\hline $\mathrm{C} 23$ & $\mathrm{C} 24$ & $\mathrm{H} 241$ & 108.8 \\
\hline C23 & $\mathrm{C} 24$ & $\mathrm{H} 242$ & 108.8 \\
\hline $\mathrm{C} 25$ & $\mathrm{C} 24$ & $\mathrm{H} 241$ & 108.8 \\
\hline $\mathrm{C} 25$ & $\mathrm{C} 24$ & $\mathrm{H} 242$ & 108.8 \\
\hline H241 & $\mathrm{C} 24$ & $\mathrm{H} 242$ & 109.4 \\
\hline C20 & $\mathrm{C} 25$ & C24 & $110.5(3)$ \\
\hline $\mathrm{C} 20$ & $\mathrm{C} 25$ & $\mathrm{H} 251$ & 109 \\
\hline $\mathrm{C} 20$ & $\mathrm{C} 25$ & $\mathrm{H} 252$ & 109.3 \\
\hline $\mathrm{C} 24$ & $\mathrm{C} 25$ & $\mathrm{H} 251$ & 109.1 \\
\hline C24 & $\mathrm{C} 25$ & $\mathrm{H} 252$ & 109.4 \\
\hline H251 & $\mathrm{C} 25$ & H252 & 109.5 \\
\hline
\end{tabular}




\begin{tabular}{|c|c|c|c|}
\hline $\mathrm{P} 2$ & $\mathrm{C} 26$ & $\mathrm{C} 27$ & $112.9(3)$ \\
\hline $\mathrm{P} 2$ & $\mathrm{C} 26$ & C31 & $112.0(3)$ \\
\hline $\mathrm{P} 2$ & $\mathrm{C} 26$ & H261 & 107.3 \\
\hline $\mathrm{C} 27$ & $\mathrm{C} 26$ & C31 & $109.8(3)$ \\
\hline $\mathrm{C} 27$ & $\mathrm{C} 26$ & H261 & 107.3 \\
\hline C31 & $\mathrm{C} 26$ & H261 & 107.2 \\
\hline $\mathrm{C} 26$ & $\mathrm{C} 27$ & C28 & $111.5(3)$ \\
\hline $\mathrm{C} 26$ & $\mathrm{C} 27$ & H271 & 108.9 \\
\hline $\mathrm{C} 26$ & $\mathrm{C} 27$ & $\mathrm{H} 272$ & 108.9 \\
\hline C28 & $\mathrm{C} 27$ & H271 & 109.1 \\
\hline $\mathrm{C} 28$ & $\mathrm{C} 27$ & H272 & 108.9 \\
\hline $\mathrm{H} 271$ & $\mathrm{C} 27$ & $\mathrm{H} 272$ & 109.5 \\
\hline $\mathrm{C} 27$ & $\mathrm{C} 28$ & C29 & $111.8(3)$ \\
\hline $\mathrm{C} 27$ & $\mathrm{C} 28$ & H281 & 108.8 \\
\hline $\mathrm{C} 27$ & $\mathrm{C} 28$ & H282 & 109 \\
\hline C29 & $\mathrm{C} 28$ & H281 & 108.8 \\
\hline $\mathrm{C} 29$ & $\mathrm{C} 28$ & H282 & 108.9 \\
\hline H281 & $\mathrm{C} 28$ & H282 & 109.5 \\
\hline $\mathrm{C} 28$ & $\mathrm{C} 29$ & C30 & $110.7(3)$ \\
\hline $\mathrm{C} 28$ & $\mathrm{C} 29$ & H291 & 109.3 \\
\hline C28 & $\mathrm{C} 29$ & H292 & 109.1 \\
\hline C30 & $\mathrm{C} 29$ & H291 & 109.2 \\
\hline C30 & $\mathrm{C} 29$ & H292 & 109.1 \\
\hline H291 & $\mathrm{C} 29$ & H292 & 109.5 \\
\hline C29 & $\mathrm{C} 30$ & C31 & $111.3(3)$ \\
\hline C29 & $\mathrm{C} 30$ & H301 & 108.9 \\
\hline C29 & $\mathrm{C} 30$ & H302 & 109 \\
\hline C31 & $\mathrm{C} 30$ & H301 & 109.1 \\
\hline C31 & $\mathrm{C} 30$ & H302 & 109.1 \\
\hline H301 & $\mathrm{C} 30$ & H302 & 109.5 \\
\hline $\mathrm{C} 26$ & C31 & C30 & $110.6(3)$ \\
\hline $\mathrm{C} 26$ & $\mathrm{C} 31$ & H311 & 109.2 \\
\hline $\mathrm{C} 26$ & C31 & H312 & 109.1 \\
\hline C30 & C31 & H311 & 109.2 \\
\hline C30 & C31 & H312 & 109.3 \\
\hline H311 & C31 & H312 & 109.5 \\
\hline $\mathrm{F} 1$ & P3 & $\mathrm{F} 2$ & $94.5(4)$ \\
\hline $\mathrm{F} 1$ & P3 & $\mathrm{F} 3$ & $86.3(4)$ \\
\hline $\mathrm{F} 1$ & P3 & F4 & $174.5(5)$ \\
\hline $\mathrm{F} 1$ & P3 & F5 & $90.7(4)$ \\
\hline F1 & P3 & F6 & $90.3(4)$ \\
\hline $\mathrm{F} 2$ & P3 & $\mathrm{F} 3$ & $93.3(4)$ \\
\hline $\mathrm{F} 2$ & P3 & $\mathrm{F} 4$ & $88.1(5)$ \\
\hline $\mathrm{F} 2$ & P3 & F5 & $174.5(5)$ \\
\hline
\end{tabular}




$\begin{array}{llll}\text { F2 } & \text { P3 } & \text { F6 } & 91.3(4) \\ \text { F3 } & \text { P3 } & \text { F4 } & 88.7(4) \\ \text { F3 } & \text { P3 } & \text { F5 } & 88.8(4) \\ \text { F3 } & \text { P3 } & \text { F6 } & 174.5(4) \\ \text { F4 } & \text { P3 } & \text { F5 } & 86.9(4) \\ \text { F4 } & \text { P3 } & \text { F6 } & 94.5(5) \\ \text { F5 } & \text { P3 } & \text { F6 } & 86.9(4)\end{array}$




\section{References}

(1) Rountree, E. S.; Martin, D. J.; McCarthy, B. D.; Dempsey, J. L. Linear Free Energy Relationships in the Hydrogen Evolution Reaction: Kinetic Analysis of a Cobaloxime Catalyst. ACS Catal. 2016, 6 (5), 3326-3335. https://doi.org/10.1021/acscatal.6b00667.

(2) Perrin, C. L.; Dwyer, T. J. Application of Two-Dimensional NMR to Kinetics of Chemical Exchange. Chem. Rev. 1990, 90 (6), 935-967. https://doi.org/10.1021/cr00104a002.

(3) Smith, K.; Pan, H.; Hondrogiannis, G.; Mamantov, A.; Pagni, R. M. The Use of TwoDimensional NMR Spectroscopy to Determine the Rates of and Activation Parameters for the 3,2-Hydride Shift in the 2-Norbornyl Cation. Arkivoc 2008, 2009 (5), 68. https://doi.org/10.3998/ark.5550190.0010.507.

(4) SAINT; Bruker Analytical X-Ray Systems. SAINT. Madison, WI, USA.

(5) Blessing, R. H. An Empirical Correction for Absorption Anisotropy. Acta Crystallogr. Sect. A Found. Crystallogr. 1995, 51 (1), 33-38. https://doi.org/10.1107/S0108767394005726.

(6) Palatinus, L.; Chapuis, G. SUPERFLIP - a Computer Program for the Solution of Crystal Structures by Charge Flipping in Arbitrary Dimensions. J. Appl. Crystallogr. 2007, 40 (4), 786-790. https://doi.org/10.1107/S0021889807029238.

(7) Betteridge, P. W.; Carruthers, J. R.; Cooper, R. I.; Prout, K.; Watkin, D. J. CRYSTALS Version 12: Software for Guided Crystal Structure Analysis. J. Appl. Crystallogr. 2003, 36 (6), 1487-1487. https://doi.org/10.1107/S0021889803021800. 